Significance of the Precambrian Basement and Late Cretaceous Thrust Nappes on the Location of Tertiary Ore Deposits in the Oquirrh Mountains, Utah 


\title{
Significance of the Precambrian Basement and Late Cretaceous Thrust Nappes on the Location of Tertiary Ore Deposits in the Oquirrh Mountains, Utah
}

\author{
By Edwin W. Tooker
}

Five Sevier-age (Late Cretaceous) east-directed nappes in the Oquirrh Mountains, Utah overlie the nearly east-directed Uinta trend (Precambrian) basement lineament zone. Unique stratigraphic and structural features in two of the nappes containing Paleozoic carbonate-rich sedimentary rocks and intrusive Tertiary igneous stocks and fissures provide evidence for this favorable local geologic setting and the occurrence of base- and precious-metal ore deposits. These include the world-class Bingham gold, copper, molybdenum porphyry, the Ophir and Stockton base metal fissure and the Mercur disseminated gold mining districts.

SIR 2004-5218

\section{U.S. Department of the Interior U.S. Geological Survey}




\section{U.S. Department of the Interior \\ Gale A. Norton, Secretary}

\section{U.S. Geological Survey Charles G. Groat, Director}

\section{U.S. Geological Survey, Reston, Virginia: 2005}

For sale by U.S. Geological Survey Information Services Box 25286, Denver Federal Center

Denver, C0 80225

This report and any updates to it are available online at: http://pubs.usgs.gov/sir/2004/5218/

For additional information write to:

U.S. Geological Survey

Box 25046, Mail Stop 421, Denver Federal Center

Denver, C0 80225-0046

Additional USGS publications can be found at: http://geology.usgs.gov/products.html

For more information about the USGS and its products: Telephone: 1-888-ASK-USGS (1-888-275-8747)

World Wide Web: http://www.usgs.gov/

Any use of trade, product, or firm names in this publication is for descriptive purposes only and does not imply endorsement of the U.S. Government.

Although this report is in the public domain, it contains copyrighted materials that are noted in the text. Permission to reproduce those items must be secured from the individual copyright owners.

Cataloging-in-publication data are on file with the Library of Congress (URL http://www.loc.gov/).

Produced in the Western Region, Menlo Park, California

Manuscript approved for publication, October 7, 2004

Text edited by James W. Hendley II

Layout and design by Susan Mayfield 


\section{Contents}

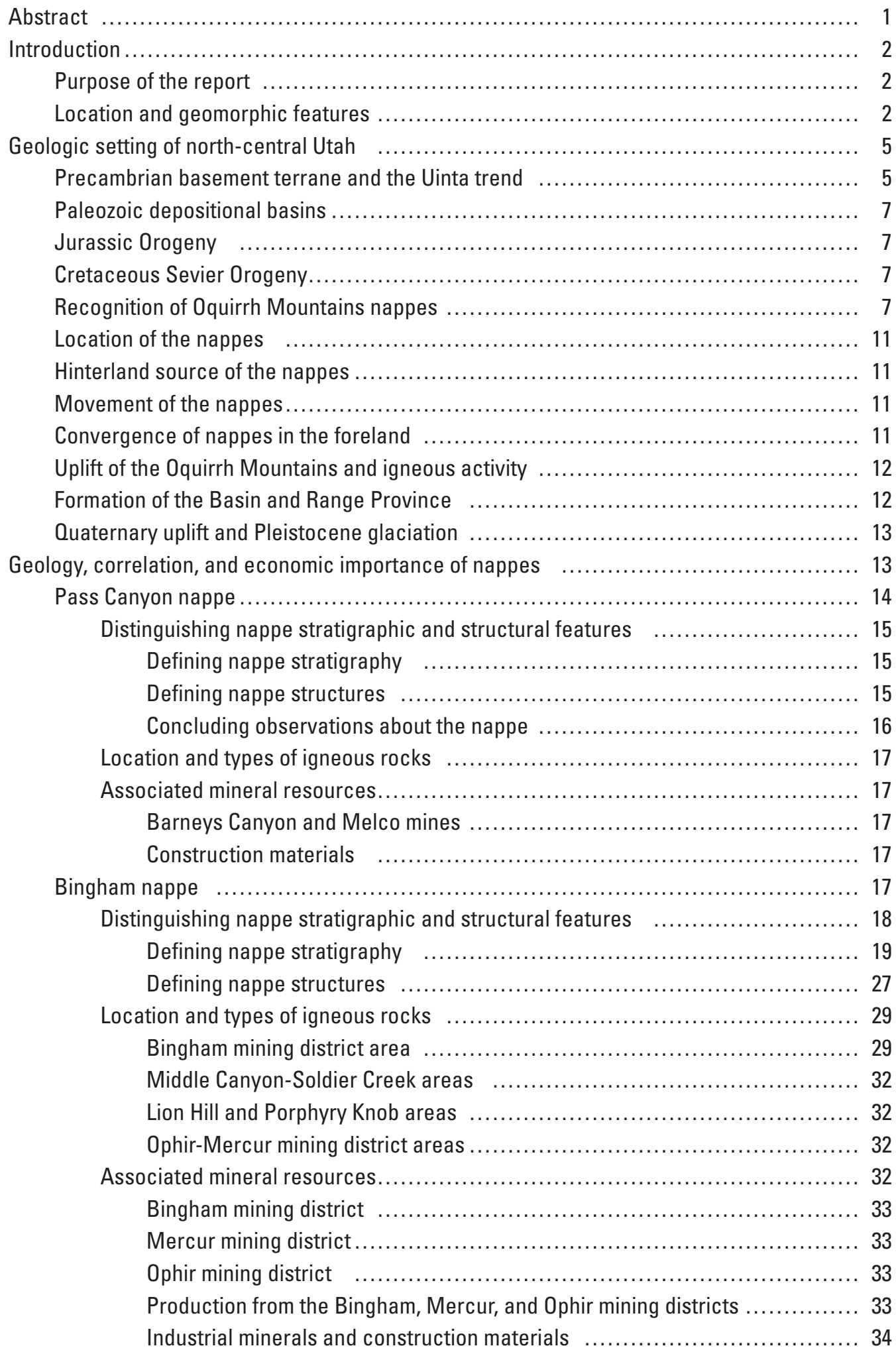




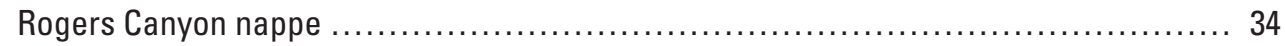

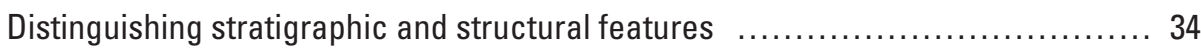

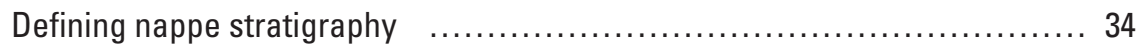

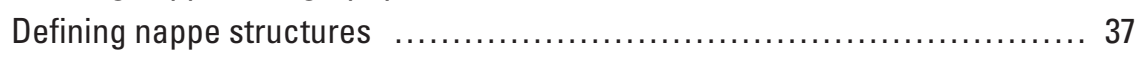

Proposed formation of Rogers Canyon nappe structure .................... 38

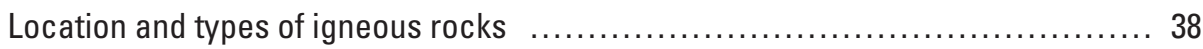

Associated mineral resources............................................. 38

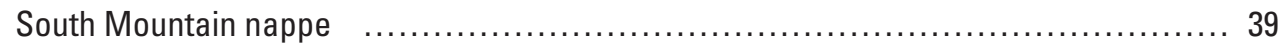

Distinguishing nappe stratigraphic and structural features $\quad \ldots \ldots \ldots \ldots \ldots \ldots \ldots . \ldots 39$

Definining nappe stratigraphy ......................................... 39

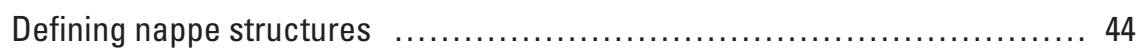

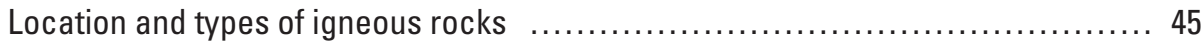

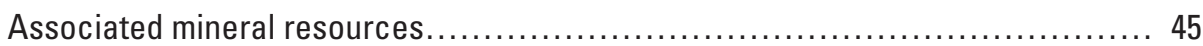

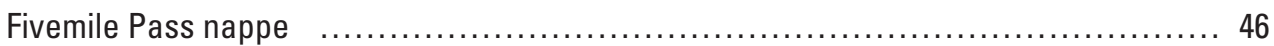

Distinguishing nappe stratigraphic and structural features $\ldots \ldots \ldots \ldots \ldots \ldots \ldots . \ldots 46$

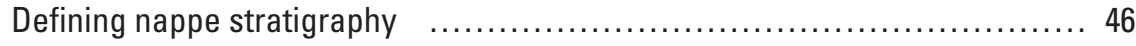

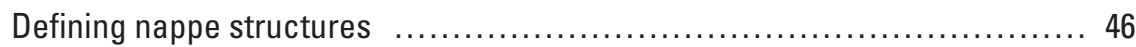

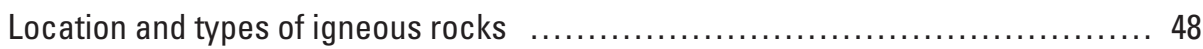

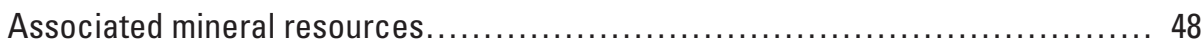

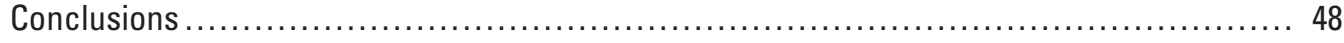

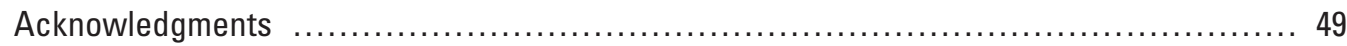

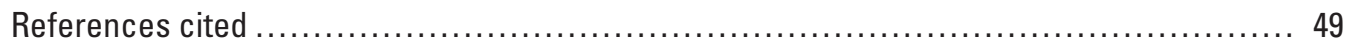

\section{Appendixes}

1. Columnar section of Permian sedimentary rocks, Bingham mining district, by Welsh and James (1961)

2. Measured sections of $(A)$ the South Peak, $(B)$ Salvation, and $(C)$ Rush Lake formational units of Tooker and Roberts (1988), in the South Mountain nappe

\section{Figures}

1. Location of the Oquirrh Mountains' 7 1/2-minute topographic quadrangles, the main mining areas and the inferred Uinta trend basement lineament

2. North-central Utah locations of the Oquirrh Mountains, the Basin and Range and Rocky Mountains physiographic provinces, and the inferred axial trace of the Uinta trend

3. Inferred locations of the Paleozoic Sublette and Oquirrh miogeoclinal deposition basins on the craton platform, and the inferred directions of individual nappe movement to their foreland sites

4. Generalized columnar sections showing th correlation of Paleozoic formations in the Oquirrh and neighboring mountain nappes

5. Inferred directions (arrows) and sequence (1 to-5) of Sevier-age nappe approaching the Oquirrh Mountains foreland

6. Locations of the Pass Canyon, Bingham, Rogers Canyon, South Mountain, and Fivemile Pass nappes in the Oquirrh Mountains 
7. Generalized geologic map of the Pass Canyon nappe ........................................................ 14

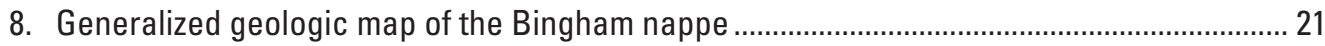

9. Generalized columnar sections, lithology of the Lower and Upper Paleozoic

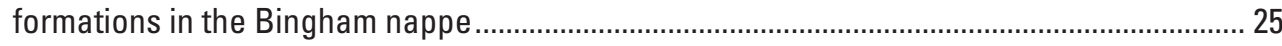

10. Principal fold and fault structures of the Bingham nappe in the Bingham mining

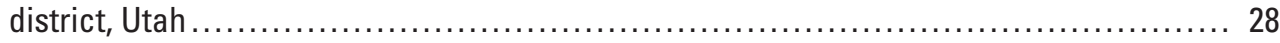

11. Distribution of igneous rocks in the Pass Canyon, Bingham, and South Mountain nappes in the central Oquirrh and South Mountains, Utah ........................... 30

12. Distribution of igneous rocks in the Bingham nappe, southern Oquirrh

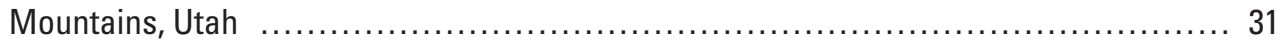

13. Generalized geologic map of the Rogers Canyon nappe .............................. 35

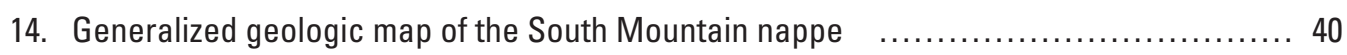

15. Comparison of columnar sections of common-age parts of the South Mountain

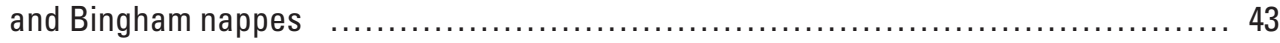

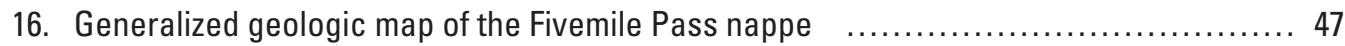

\section{Tables}

1. Igneous rock occurrences in the Oquirrh Mountains nappe .................................................. 13

2. Lithology of Paleozoic formations in the Pass Canyon nappe ................................................. 15

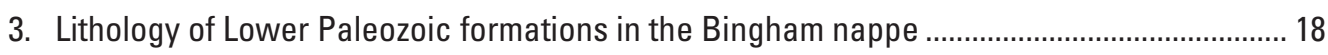

4. Lithology of Upper Paleozoic formations in the Bingham nappe.......................................... 22

5. Production of base and precious metals in the Bingham Mercur, Stockton and Ophir mining districts in the Bingham and South Mountain nappes................................. 23

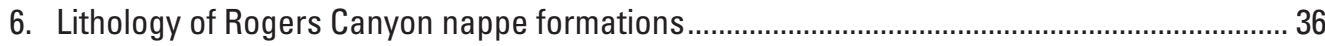

7. Lithology of South Mountain nappe formations .................................................................... 41

8. Lithology of Fivemile Pass nappe formation........................................................................ 46 


\title{
Significance of the Precambrian Basement and Late Cretaceous Thrust Nappes on the Location of Tertiary Ore Deposits in the Oquirrh Mountains, Utah
}

\author{
By Edwin W. Tooker
}

\section{Abstract}

The Oquirrh Mountains are located in north central Utah, in the easternmost part of the Basin and Range physiographic province, immediately south of the Great Salt Lake. The range consists of a northerly trending alignment of peaks $56 \mathrm{~km}$ long. Tooele and Rush Valleys flank the Oquirrh Mountains on the western side and Salt Lake and Cedar Valleys lie on the eastern side. The world class Bingham mine in the central part of the range hosts disseminated copper-bearing porphyry, skarn, base-and precious-metal vein and replacement ore deposits. The district includes the outlying Barneys Canyon disseminated-gold deposits. Disseminated gold in the Mercur mining district in the southern part of the range has become exhausted. The Ophir and Stockton base- and precious-metal mining districts in the range north of Mercur also are inactive. A geologic map of the range (Tooker and Roberts, 1998), available at a scale of 1:50,000, is a summation of U.S. Geological Survey (USGS) studies.

Information about the range and its mining areas is scattered. This report summarizes map locations, new stratigraphic and structural data, and reexamined data from an extensive published record. Unresolved controversial geological interpretations are considered, and, for the first time, the complete geological evidence provides a consistent regional basis for the location of the ore deposits in the range.

The geological setting and the siting of mineral deposits in the Oquirrh Mountains began with the formation of a Precambrian craton. Exposures of folded Proterozoic basement rocks of the craton, in the Wasatch Mountains east of Salt Lake City, were accreted and folded onto an Archean crystalline rock terrane. The accretion suture lies along the north flank of the Uinta Mountains. The western part of the accreted block was offset to northern Utah along a north-trending fault lying approximately along the Wasatch Front (Nelson and others, 2002), thereby creating a prominant basement barrier or buttress east of the Salt Lake area.

The accretion suture along the north flank of the Uinta Anticline overlaps an earlier Precambrian east-west mobile zone, the Uinta trend (Erickson, 1976, Bryant and Nichols,
1988 and John, 1989), which extends westward across western Utah and into Nevada. A trace of the trend underlies the middle part of the Oquirrh Mountains. Its structure is recognized by disrupted Paleozoic stratigraphic units and fold and fault evidence of thrust faulting, intermittent local uplift and erosion, the alignment of Tertiary intrusives and associated ore deposits. Geologic readjustments along the trend continued intermittently through the Paleozoic, Cenozoic, Tertiary, and the development of clastic deposits along the shores of Pleistocene Lake Bonneville.

Paleozoic sedimentary rocks were deposited on the craton platform shelf in westernmost Utah and eastern Nevada as the shelf subsided gradually and differentially. Debris was shed into two basins separated by the uplifted Uinta trend, the Oquirrh Basin on the south and Sublette Basin on the north. Sediments were derived from the craton to the east, the Antler orogenic zone on the west (Roberts, 1964), and locally from uplifted parts of the trend itself. Thick accumulations of clastic calcareous quartzite, shale, limestone, and dolomite of Lower and Upper Paleozoic ages are now exposed in the Oquirrh Mountains, the result of thrust faults.

Evidence of decollement thrust faults in in the Wasatch Mountains during the Late Cretaceous Sevier orogeny, recognized by Baker and others (1949) and Crittenden (1961, is also recognized in the Oquirrh Mountains by Roberts and others (1965). During the late Cretaceous Sevier Orogeny, nappes were thrust sequentially along different paths from their western hinterland to the foreland. Five distinct nappes converged over the Uinta trend onto an uplifted west-plunging basement buttress east of the Oquirrh Mountains area: the Pass Canyon, Bingham, Rogers Canyon, South Mountain, and Fivemile Pass nappes (Tooker and Roberts, 1998). The defining stratigraphic and structural bases for nappe recognition are indicated in this report.

Local, thinned, tightly folded and fractured leading edges of sole and imbricate thrust faults overlying the mobile Uinta trend zone, became sites for Tertiary (Oligocene) intrusive and extrusive rocks and associated late-stage hydrothermal precious metal disseminated porphyry, skarn, and adjoining vein deposits. Regional Basin-and-Range faults in the Great 
Basin during the late Cenozoic formed the present Oquirrh Mountains. The current topography of the range results from continuing uplift of the Uinta trend zone and erosion during the early Quaternary.

\section{Introduction}

The Oquirrh Mountains are the site of one of the most prominent base- and precious-metal mining areas of western United States (Singer, and others, 2002). The range has supplied base and precious metals, industrial minerals, and construction materials from four mining areas - the currently active Bingham mining district, which includes the nearby Barneys Canyon and Melco mines, and the now inactive Mercur, Ophir, and Stockton mining districts

Much is known about the geology of the individual ore deposits in these districts and of the Oquirrh Mountains, but that information is dispersed and has not been fully integrated within a current regional geologic model. Complex geologic structures and poorly differentiated stratigraphic relationships in the range are not fully resolved. This summary and status of knowledge about the geology of the range attempts to clarify apparent differences of interpretation that have arisen. It is based on investigations by the author and his USGS colleagues.

\section{Purpose of the Report}

Some descriptions of the geology of individual parts of the range are as much as 1 to 12 decades old (Murphy, 1872; Spurr, 1895; Boutwell, 1905a,b; Wegg, 1915; Beeson, 1917 and 1925; Hunt, 1924 and 1933; Peterson, 1924; Gilluly, 1932; and Hammond, 1961). The most recent discussion of the geology of the Oquirrh Mountains as a whole by Butler (1920) is more than 75 years old. However, there are a number of more recent geologic descriptions of local (mining) areas in the range. These are published in field trip guides, mining company reports, and are in university faculty and student theses (Peacock, 1948; Field, 1966; James and others, 1961b; Cook 1961; Einaudi, 1975; James, 1978 and 1982; Wilson and Parry, 1995); Presnell, 1992; Presnell and Parry, 1996; Krahulac, 1997; Babcock, and others, 1997; Melker and Geissmand, 1997; and Gunter and Austin, 1997.

This report is the author's updated evaluation of the regional geology of the Oquirrh Mountains area; it also considers some of the controversial not fully resolved differences from past geologic analyses. The report primarily describes and summarizes the regional geologic relations observed by USGS maps of all or parts of fourteen 7 1/2-min. quadrangles (at a 1:24,000 scale) ${ }^{1}$, which include the Oquirrh Mountains (fig. 1). A compilation of these maps by Tooker, and Roberts

\footnotetext{
${ }^{1}$ Mills Junction, Farnsworth Peak (formerly Garfield), Magna, Tooele, Bingham Canyon, Lark, Stockton, Lowe Peak, Tickville Springs, South Mountain, Ophir, and Mercur.
}

(1998) at 1:50,000 scale provides the geologic foundation for the author's assessment of the geological occurrence of ore deposits in the Oquirrh Mountains.

Geophysical and geochemical studies are by the USGS (Mabey, 1960; Cook and Berg, 1961; Mabey and others, 1963, 1964, 1978; Zietz and others, 1976; and Stein and others, 1989), mining companies (Kornze and others 1985), the Utah Geological Survey (Lenzi, 1971), and university students and instructors (Wilson and Parry, 1994). During this same period, several mining company exploration and development programs and a number of university faculty geologic research programs and student theses have been completed (Wilson, 1986, Wilson and Parry, 1995; and Presnell and Parry, 1996); these results are added to an emerging complex regional geologic model.

More detailed geologic and geophysical studies completed within the mining districts, particularly those by the mine staffs of Kennecott Corporation (Babcock and others, 1995) and Barrick Mercur Gold Mines, Inc. (Kornze and others, 1985) have continued since the completion of the USGS's regional mapping research. One of most recent geophysical reports by Nelson and others (2002) provides a solution for one of the perplexing Percambrian basement structures - the apparent occurrence of a barrier or buttress east of the Salt Lake area.

Geologic science has advanced during the recent years with the advent of plate tectonics, as well as the availability of increasingly sophisticated geologic field and laboratory technology. Continuing world-class mining activity at Bingham (Singer, and others, 2002) and interest in gold exploration in the Oquirrh Mountains and elsewhere in Utah are the primary justifications for compiling and reevaluating the geologic information derived from recent geologic research by the USGS, mining companies, and university faculty and students.

Differences in geologic interpretation of observations by geologists with dissimilar professional perspectives, objectives, and experiences have developed some alternative interpretations, which are noted in this report. The geologic descriptions and interpretations that follow, however, are the author's responsibility. Diversity of opinion eventually leads geologists to conceive critical research to resolve these differences. Contribution to such resolution is the ultimate objective of this report.

\section{Location and Geomorphic Features}

The Oquirrh Mountains rise at the south end of the Great Salt Lake, about $25 \mathrm{~km}$ west of Salt Lake City, Utah. They constitute the first of a series of north-trending mountain ranges in the eastern part of the Basin and Range physiographic province in west central Utah (fig. 2). The Wasatch Fault, a prominent north-trending structure along the western margin of the Wasatch Range, lies east of the Oquirrh Mountains, and is the boundary separating the northern Rocky Mountains province on the east and the Great Basin part of the Basin and Range Province on the west. Stretching 56 $\mathrm{km}$ due south from the south end of the Great Salt Lake, the Oquirrh Mountains end at Fivemile Pass, which separates the 


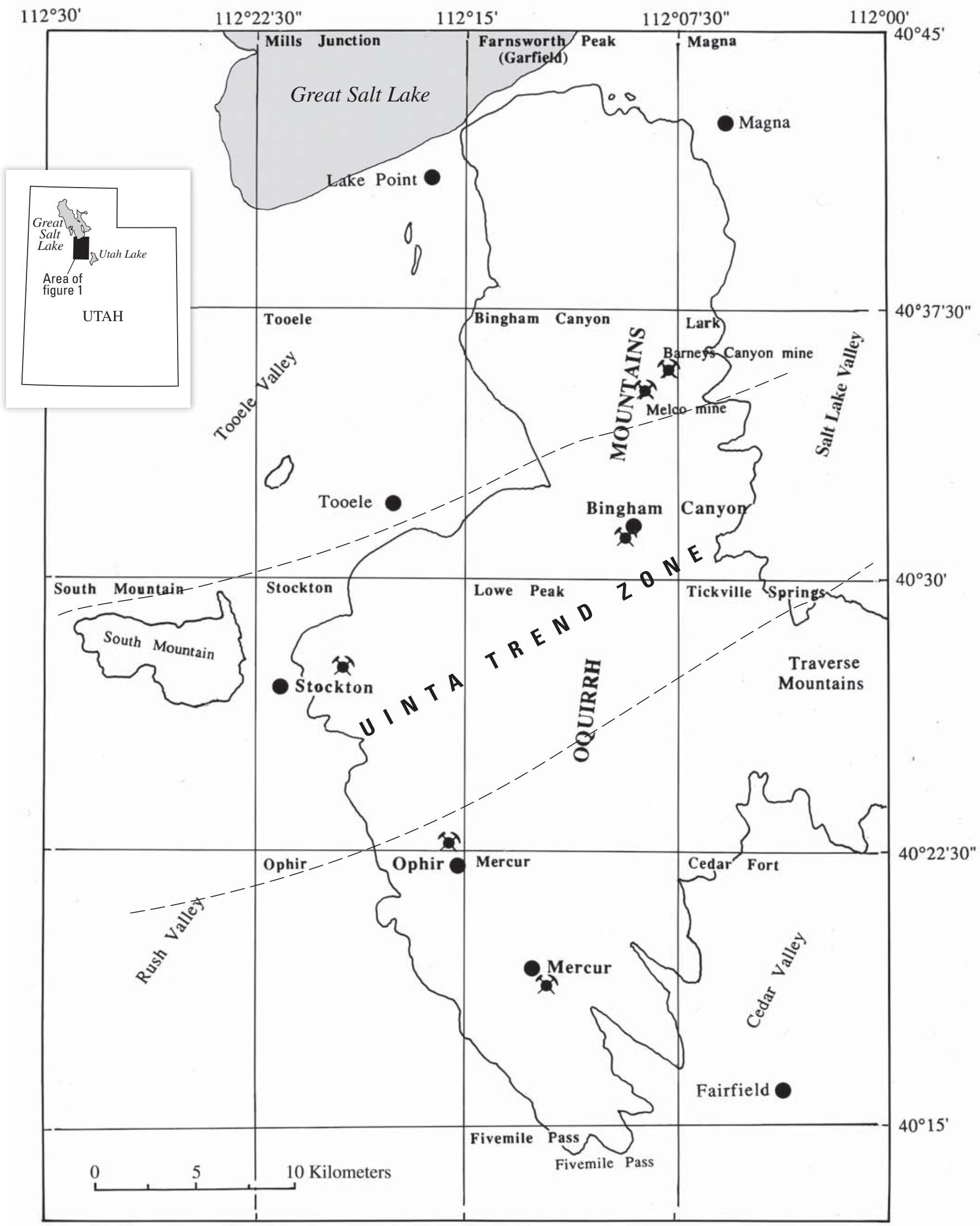

Figure 1. Map showing the location of the Oquirrh Mountains, Utah, its constituent 7 1/2-minute topographic quadrangles, and the main mining areas (pick and hammer symbols). The inferred Uinta trend zone (between dashed lines) is also shown. 


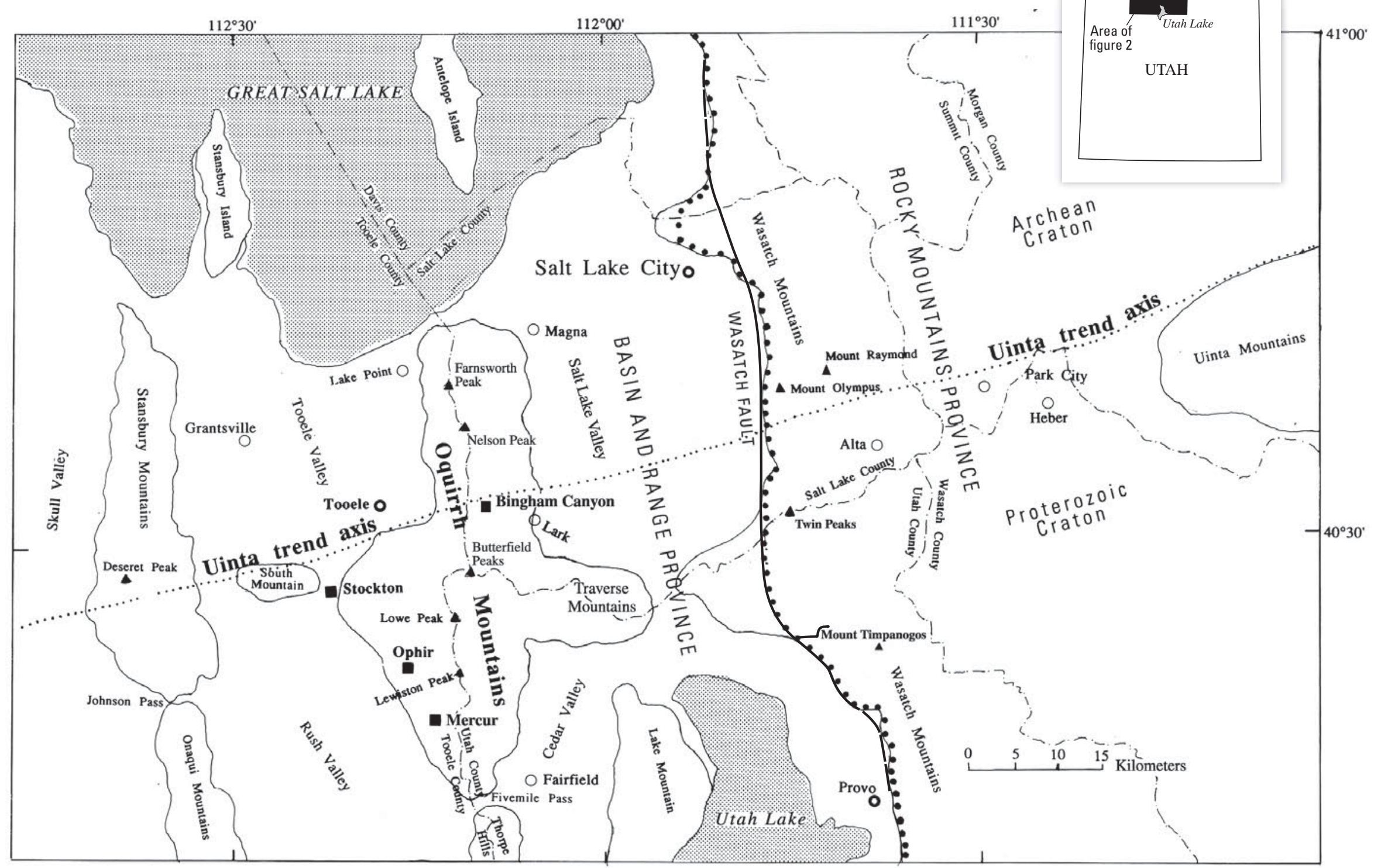

Figure 2. North central Utah locations of the Oquirrh Mountains and neighboring ranges, the Precambrian cratons, the Basin and Range and Rocky Mountains physiographic provinces, and the inferred generalized axial trace of the basement Uinta trend zone. Heavy dotted line indicates Physiographic Province boundary. 
range from the Thorpe Hills. Antelope Island, lying $14 \mathrm{~km}$ to the north in the Great Salt Lake, is aligned with the Oquirrh Mountains but is composed of much older rocks than those in the range. The Great Salt Lake is the vestigial remnant of a large Pleistocene freshwater body, Lake Bonneville.

The Oquirrh Mountains consist of a series of coalescing peaks that emerge abruptly from the south shore of Great Salt Lake, at about 1,280 m (4,200 ft), and rise up to 2,852 m $(9,356 \mathrm{ft})$ elevation at Nelson Peak in the northern part of the range (fig. 2). The ridgeline drops down to $2,499 \mathrm{~m}(8,200 \mathrm{ft})$ in the vicinity of the Bingham Canyon in the central part of the range. The highest point of the range is Lowe Peak, elevation $3,228 \mathrm{~m}(10,589 \mathrm{ft})$, in the southern part. The range gradually descends to Fivemile Pass at about 1,676 m (5,500 ft).

Two topographically lower-lying, east-west-trending spur ranges flank the central part of the Oquirrh Mountains. South Mountain is a separate narrow outlier that trends west from the western side of the Oquirrh Mountains. The western Traverse Mountains join the Oquirrh Mountains on its eastern side. However, these lower mountain masses are integral and geologically compatible adjuncts to the main Oquirrh Mountains. The highest and broadest part of the Oquirrh Mountains is aligned with the east-west crossing axis of the western Traverse Mountains and South Mountain. Salt Lake and Cedar Valleys, which flank the range on the eastern side, are separated by the Traverse Mountains. South Mountain separates Tooele and Rush Valleys, which lie on the western side of the range.

The Oquirrh Mountains host five base- and preciousmetal mining districts. The Bingham mining district, located about $32 \mathrm{~km}$ southwest of Salt Lake City in the central part of the range (fig. 2), is classed as a porphyry copper deposit of world-class magnitude by Singer and others (2002). The more recently developed Barneys Canyon and Melco disseminated gold mines lie about $6 \mathrm{~km}$ north of the Bingham mine. The Mercur disseminated gold mine (and the adjoining Sunshine mining area), and the base and precious metal Ophir, and Stockton mining districts are located on the western side in the southern half of the range. Mercur lies $59 \mathrm{~km}$ southwest of Salt Lake City, and the Ophir and Stockton districts lie 7 and $18 \mathrm{~km}$, respectively, north-northwest of Mercur.

The Oquirrh Mountains also contain industrial mineral resources in addition to extensive deposits of sand and gravel, which occur irregularly about the range in alluvial fans and shoreline bar and spit deposits. Calcite oolite sands (for flux in smelting) were once mined about the southern shores of the Great Salt Lake, and brick clay and limestone (also used for flux) were mined in the southern parts of the Oquirrh Mountains. A small deposit of the semi-precious mineral variscite also occurs in limestone at the south end of the range.

\section{Geologic Setting of North-Central Utah}

The central Utah terrane was developed during a succession of geologic events extending from the Precambrian to present times. The formation of a Precambrian craton includes development of a buttress in the Wasatch Mountains in concert with the Uinta trend, which is a persistent mobile, east-west lineament underlying the Oquirrh Mountains and the ranges extending westward. Paleozoic sedimentation in the miogeoclinal basins west of the craton resulted from erosion of the craton and the later Antler highland in Nevada. Jurassic and late Cretaceous orogenies created structural regimes above the Uinta trend that later were modified by formation of the late Cenozoic Basin and Range Province. Mid-Tertiary igneous activity and ore deposition also occurred locally along the Uinta trend. Quaternary uplift and erosion completed formation of the present land surfaces.

\section{Precambrian Basement Terrane and the Uinta Trend}

A stratigraphically and structurally complex Precambrian basement (cratonal) terrane underlies north-central Utah and extends westward into central Nevada (Eaton, 1982; Anderson and others, 1983; and Reed and others, 1993). Precambrian rocks crop out in the Uinta and Wasatch Ranges (Crittenden and others, 1952; Condie, 1969; Crittenden, 1976; Bryant and Nichols, 1988; and Bryant, 1993), on Antelope Island in the Great Salt Lake, and locally in west central Utah (Levy and Christie-Blick, 1989). Although much of this terrane is concealed west of the Wasatch Fault line in central Utah, geophysical data indicate its presence underlying the eastern Great Basin (Kistler and Peterman, 1978; Eaton and others,1978; Mabey and others, 1978; Bankey and Campbell, 1989; Henstock and others, 1998; and Nelson, and others, 2002).

The basement includes two Precambrian rock terranes (King and Beikman, 1974; Sears and others, 1982; and Bryant and Nichols, 1988). They are exposed in the Wasatch Mountains near Salt Lake City. Crystalline rocks of the Archean Wyoming shield, described by King (1976) and Bryant (1979), lie north of a generally east-west-trending fault zone along the north flank of the Uinta Mountains. South of this zone, a predominantly Proterozoic oceanic terrane forms the core of the Uinta Mountains (Blick, 1979; Nelson and others, 2002).

Analysis of isotopic data for crystalline rocks by Nelson and others (2002) indicates that the folded Proterozoic rocks are accreted onto the Archean Wyoming shield from the south along an east-west suture north of the east-trending Uinta Mountains. They show that the western part of the leading edge of this accreted structure is faulted and offset northward into northern Utah, approximately along the line of the Wasatch Mountain front. A structural basinal low west of this fault became alined with the Uinta Anticline. The Uinta Anticline produced on the accreted plate east of the Wasatch Front and the underlying Wyoming shield provided a structural high or buttress along the range front in this area. In contast, the Wyoming Basin, which lies to the north, and the Uinta Basin, lying south of the Uinta axis, were structural lows.

A belt of Tertiary intrusions and volcanic rocks extend westward from the Uinta Mountains suture (Johns, 
1989; Vogel, and others, 2002). This zone, the Uinta trend of this report, persists as an intermittent mobile structure in the Oquirrh Mountains and the ranges on-line to the west during the Paleozoic to Pleistocene, impacting sedimentary and igneous rocks above it.

There are several lines of evidence for the Uinta trend: (1) A number of west-trending linearly disposed intrusive and extrusive rocks of Tertiary Miocene age in the Wasatch Mountains and in mountain ranges of the Great Basin west of the Wasatch Fault (Armstrong and others, 1969; Moore and others,1979; Moore and McKee,1983 and John (1989). (2) Evidence of local uplift and erosion of sedimentary rocks overlying the Bingham plutons during Oligocene igneous activity (Slentz, 1955). (3) Evidence of irregular, periodic local uplifts along the trend in western Utah and eastern Nevada during the Paleozoic
(Webb, 1958; Coats, 1987; Brooks, 1956; and Roberts and Tooker, 1969). (4) Uplift and local erosion deposits in Pleistocene Lake Bonneville. (5) Geophysical data of Bankey and Campbell (1989) also support the existence of the trend.

Field and Moore (1971) report an isotopic signature for the Bingham intrusives that indicates their derivation, in part at least, from crustal rocks. This implies that the trend has deepreaching roots. However, Farmer and DePaolo (1983) have challenged the validity of this isotopic signature.

There is added indirect evidence from regional geochemical data that identifies minor amounts of platinum occurring in ore deposits along a zone overlying the Uinta trend from Ely, Nevada, to southeastern Wyoming (Page and Tooker, 1979; Tooker 1979). The source of this platinum anomaly also is assumed to be deepseated.

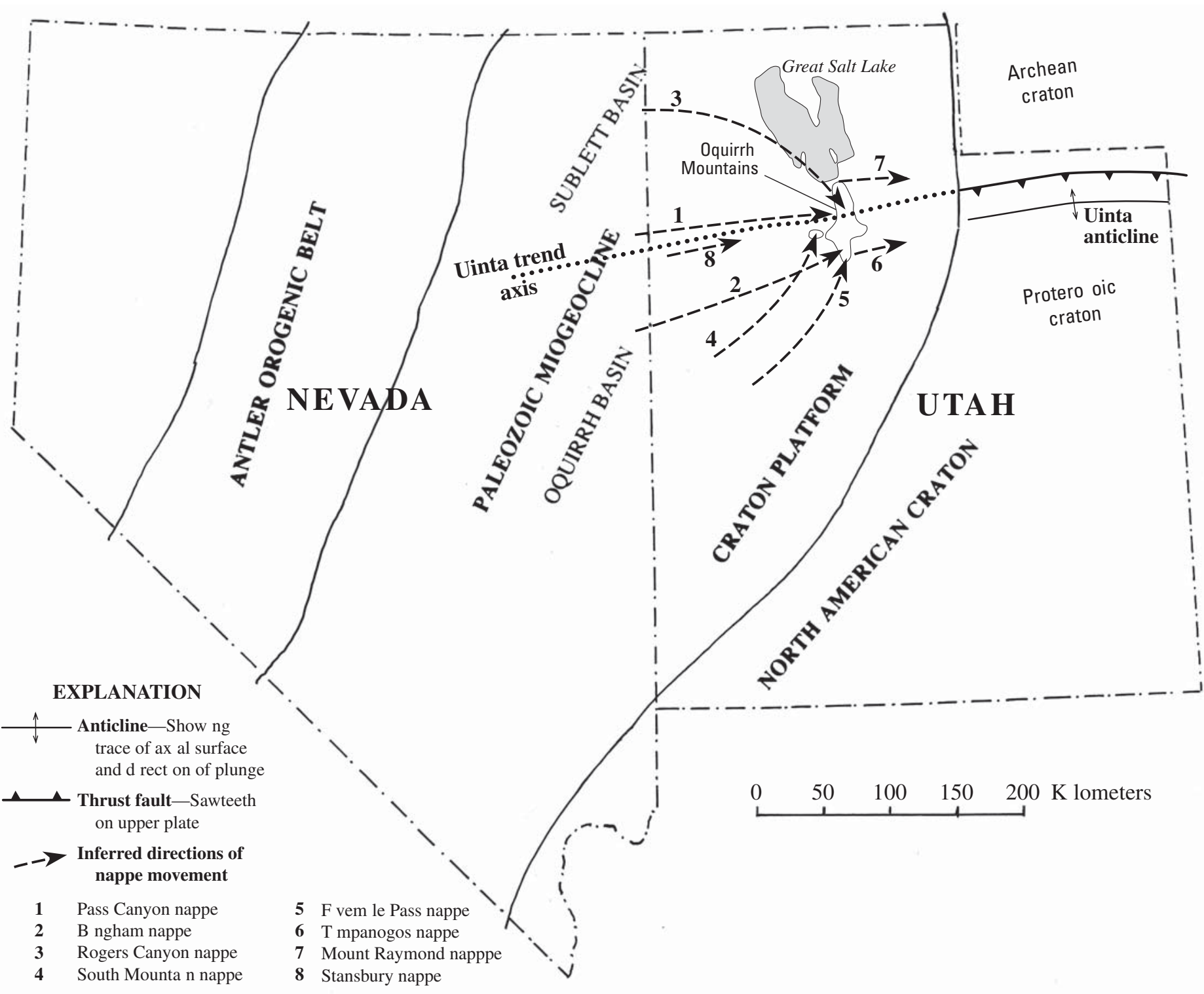

Figure 3. Inferred locations of the Paleozoic miogeoclinal Oquirrh and Sublette Basin deposition areas on the craton platform, the North American Craton and Antler orogenic belt sediment source areas, and inferred directions of individual nappe movement to their foreland sites along the Uinta-trend axis. 


\section{Paleozoic Depositional Basins}

An uplifted Uinta trend crosses the Paleozoic miogeocline in a west-southwest direction, separating the depositional area into two basins, the Oquirrh Basin on the south side, and the Sublette Basin on the northern side of the trend (fig. 3). A thick sequence of Oquirrh Basin sediments was deposited on an irregular, broad, gradually and differentially subsiding, shallowly submerged craton shelf, presumably located in what is now western Utah and eastern Nevada (Stewart and Poole, 1974; Peterson, 1977). These sedimentary rocks crop out both in the Timpanogos nappe in the Wasatach Mountains (Baker and others, 1949, Tooker, 1983) and in the Bingham nappe in the Oquirrh Mountains (Tooker and Roberts, 1970). A much thinner sequence of Sublette Basin sediments in the hinterland was deposited on a more slowly subsiding shelf. These rocks crop out in the Rogers Canyon nappe in the Oquirrh
Mountains (Tooker and Roberts, 1970) and in the Mount Raymond nappe in the Wasatch Mountains (Crittenden, 1959, Tooker, 1983). The general characteristics of the two contrasting sequences of sedimentary rocks, shown in figure 4 , are discussed later in more detail.

Overall, the Paleozoic rocks exposed in the Oquirrh Mountains are mainly thick accumulations of various combinations of Paleozoic carbonate-quartz clastics, orthoquartzite, shale, limestone, and dolomite (Tooker and Roberts, 1970). They contain an abundant fauna of macro and microfossils. These indicate deposition on a generally shallow, slowly subsiding, miogeoclinal craton shelf environment (Gordon and Duncan, 1970). During the early Paleozoic, well-sized,

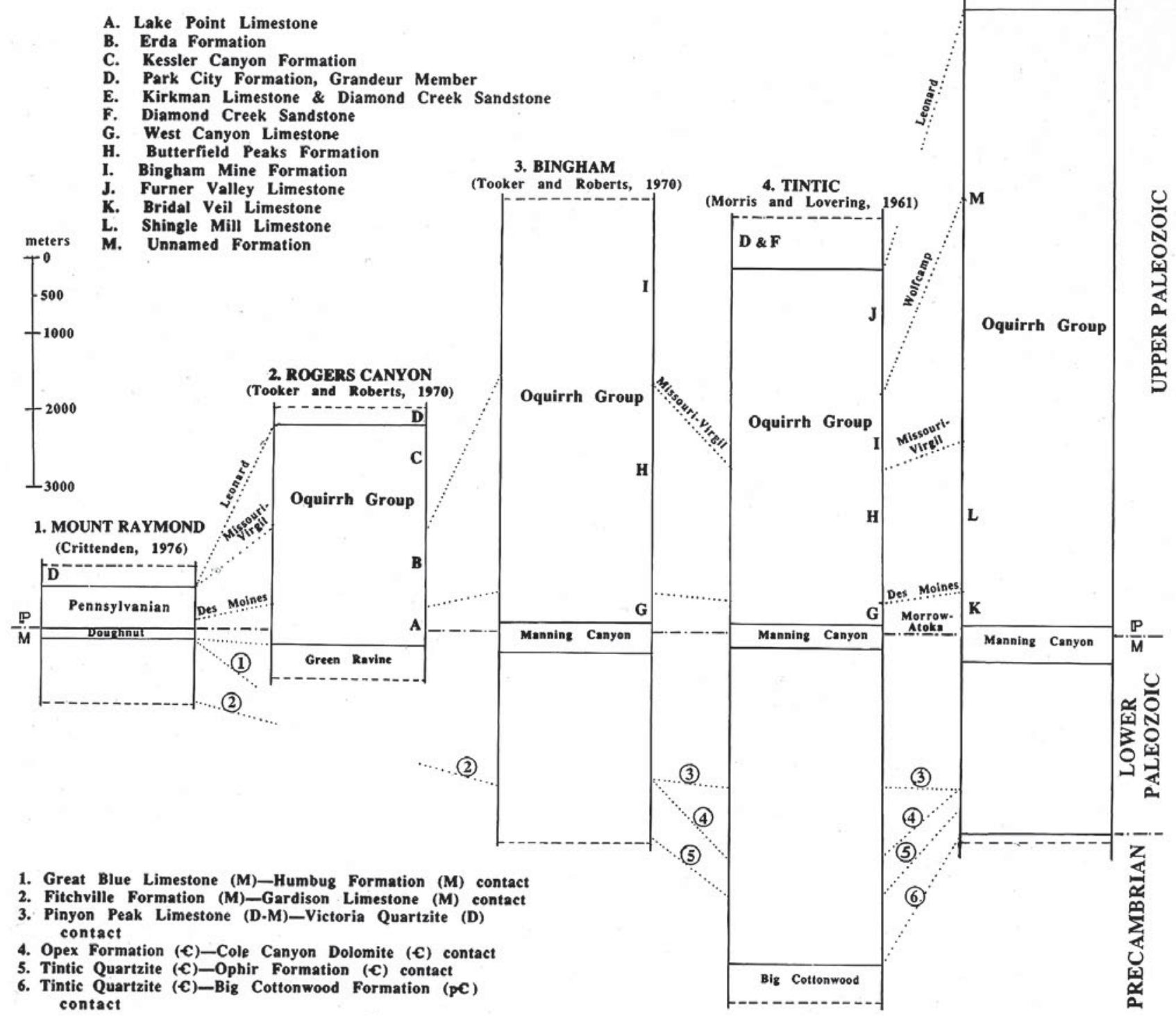

Figure 4. Generalized columnar sections showing the correlation of Paleozoic formations in the Sevier belt foreland nappes in the Oquirrh, East Tintic, and Wasatch Mountains. 
clean sedimentary materials were derived from the rising and eroding continental craton to the east. Later, during mid and upper Paleozoic time, sedimentary debris originating north of the Uinta trend in the Sublette Basin part of the miogeocline also began to include less well-sized, mixed source materials from the erosion of a rising Antler belt farther west, which was composed of oceanic-derived rocks (Roberts, 1964; Poole, 1974; and Wilson and Laule, 1979). The composition of the resulting sedimentary rocks in the Oquirrh and Sublette Basins varied during time as well as along the shelf, depending on their proximity to and the relative contributions of materials from contrasting sources of sedimentary materials (Tooker and Roberts, 1988).

Structural factors along the Uinta trend complicate the early Paleozoic miogeoclinal stratigraphic record of the hinterland area. Uplift along the trend, beginning in early Ordovician time resulted in an absence of Ordovician, Silurian, and much of the Devonian sedimentary record in the part of Bingham nappe in the Oquirrh Mountains owing to non-deposition or erosion (Gilluly, 1932, Roberts and others, 1965; and Tooker, 1983). The Stansbury disturbance in Late Devonian time, described by Brooks (1956), Rigby (1959), Morris and Lovering (1961), and Roberts and Tooker, (1969), also initiated arching, uplift and faulting along parts of the Uinta trend producing the conglomerates of the Stansbury Formation. Local conglomeratic lenses lying north of the trend in the Pennsylvanian-age rocks of Elko County, Nevada, are reported by Coats (1987). The Uinta trend can not be reliably inferred farther west than Eureka, Nevada, because of the overlap of thrust plates from the west during the Antler orogeny in Late Devonian or Early Mississippian time.

\section{Jurassic Orogeny}

Late Jurassic plutonism and deformation (Allmendinger, and others, (1984) occurred in the eastern Nevada-northwestern Utah area, the probable hinterland of the Sevier-age thrusts. Miller and Hoisch (1995) review the evidence of localized magma plutons and metamorphosed wallrocks accompanying modest local thrusts with minimal frontal breakout. According to Camilleri and others (1984), the Sevier hinterland in northeast Nevada experienced two Mesozoic metamorphic events. A Late Jurassic event is characterized by contact metamorphism about sparse upper- to mid-crustal syntectonic plutons and synchronous crustal shortening and thickening. They propose that a Late Cretaceous regional metamorphism of the crust resulted in major crustal thickening and provided a mechanism for producing the Sevier-age decollement thrusts in Utah.

Wilson and Parry (1995) report that the K-Ar ages of illite-rich clays in altered and mineralized limestone from the Mercur mining district in the Oquirrh Mountains range from 98.4 to 226 Ma. From this they estimate that the main alteration-gold mineralization event occurred at about $152 \pm 4 \mathrm{Ma}$ and thus may be correlated with the Late Jurassic orogeny. Presnell and Parry (1996) conclude that folds in the Oquirrh Mountains at the Barneys Canyon deposit in the Pass Canyon nappe also were formed by this same Jurassic orogenic episode. Their analysis implies a much broader Jurassic structural event than the more localized event proposed by Miller and Hoisch (1995). An analysis of this seeming contradiction in the timing of thrusts is considered later in this report.

\section{Cretaceous Sevier Orogeny}

The Sevier Orogeny was proposed by Armstrong (1968b) in the eastern Great Basin. The orogeny is marked by extensive decollement thrust faulting in the western parts of Utah. Baker and others (1949) first reported an anomalous juxtaposition of sedimentary rock sequences comprising stratigraphically similar thick and thin miogeoclinal shelf units in the Wasatch Mountains (the Mount Timpanogos and Mount Raymond sequences of Tooker and Roberts, (1962). They conclude that the positioning of the nappe is the result of sequential eastward transport of stratigraphic plates of Paleozoic rocks by thrust faults during a compressional phase of the Late Cretaceous Sevier Orogeny. The Timpanogos and Mount Raymond nappes (fig. 3) were the first of a series that moved eastward on thrust faults. They were followed by the nappes exposed on the Oquirrh Mountains and Stansbury Mountains (Roberts and others, 1965). These thrusts are part of a decollement zone that extends discontinuously from Alaska to Mexico (Armstrong, 1968a; and Roberts and Crittenden, 1973).

The thrust nappes approached topographically different parts of the craton foreland. In Wyoming and south central Utah, the thrusts moved into topographic lows that permitted farther eastward penetration and relatively little fragmentation of them (Oriel and Armstrong, 1966 and Morris,1983). Thrust lobes that converged in the Oquirrh Mountains area underlain by the uplifted Uinta trend buttress were fragmented into separate nappes ${ }^{2}$.

Evidence of the erosion of the Sevier nappe's foreland is observed in late Mesozoic and Cenozoic strata deposited on the craton platform east of the Wasatch Mountains. Sedimentary rock deposits consist mainly of clastic conglomerate, sandstone, shale, and lesser carbonate sediments that were derived from erosion of the foreland of Sevier thrust plates (Spieker, 1946; Lawton and others, 1993; and Heller and Paola, 1989).

\section{Recognition of Oquirrh Mountains nappes}

Five Oquirrh Mountains nappes coalesced sequentially in the Oquirrh Mountains (Tooker and Roberts, 1970) (fig. 5). Stratigraphic and structural features previously thought to be indistinguishable are now identified. Differences in their stratigraphic composition suggests that they were derived from different parts of the miogeocline (Tooker, 1970, 1983)

\footnotetext{
${ }^{2} \mathrm{~A}$ nappe, as used here, is a sheetlike allochthonous structural unit formed by thrust faulting. The nappe, in turn, may contain lesser imbricate overlying thrust faults.
} 
EXPLANATION

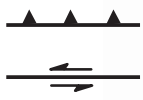

Thrust fault-Sawteeth on upper plate

Strike-slip fault-Arrows show relat ve mot on

Quadrangles Nappes

$\begin{array}{ll}\text { A } & \text { B ngham Canyon } \\ \text { B } & \text { Stockton } \\ \text { C } & \text { i owe Peak } \\ \text { D } & \text { Oph } \mathrm{r} \\ \text { E } & \text { Mercur }\end{array}$

1 Pass Canyon

2 B ngham

3 Rogers Canyon

4 South Mounta $n$

E Mercur

5 F vem le Pass

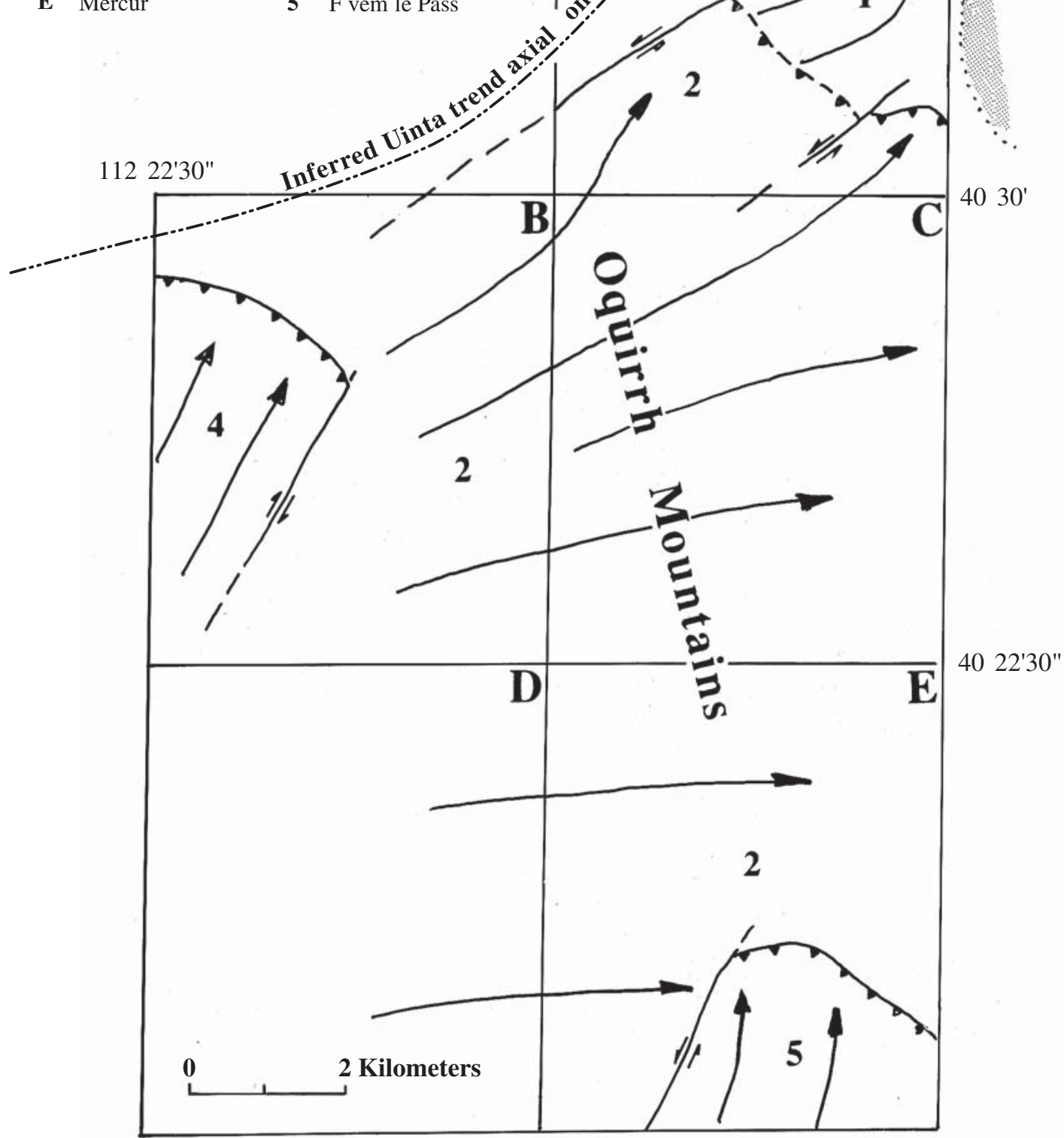

Figure 5. Diagram showing the inferred directions (arrows) and movement sequence (1 to 5) of Sevierage nappes $(A-E)$ approaching their foreland placement areas on and about the Uinta trend basement buttress in the present Oquirrh Mountains. Shaded area is inferred foreland. 


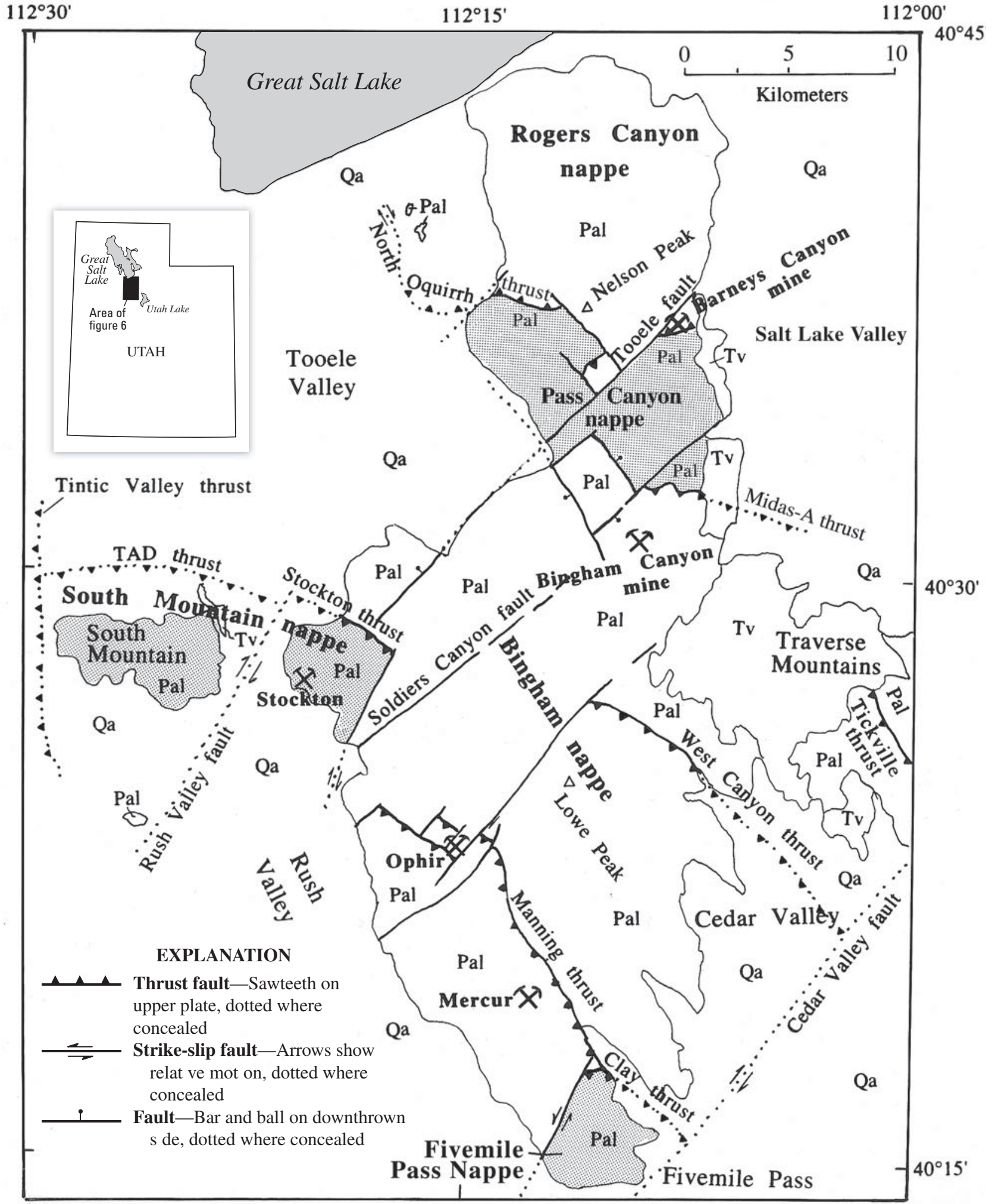

Figure 6. Location of the Rogers Canyon, Pass Canyon, Bingham, South Mountain, and Fivemile Pass nappes, the main mining areas and the principal connecting fault structures in the Oquirrh Mountains. Shading helps differentiating the nappes. 
in the Oquirrh and Sublette miogeocline basins (Tooker and Roberts, 1988).

Regional-scale thrust faulting in the Wasatch Range during the Sevier orogeny is described by Baker and others (1949), Armstrong and Oriel (1965), and Armstrong (1968b). A broader distribution of thrust faults in Utah is identified by Roberts, and others (1965), Roberts and Crittenden (1973), and Beutner (1977). The maps of the thrust belt in the Oquirrh Mountains by Tooker and Roberts (1998) show the merging of the five thrust plates, indicate the directions of their movement into the foreland, and demonstrates differences in the stratigraphy and structures of Paleozoic sedimentary rocks (Tooker, 1983). Most of the thrust faults underlying individual plates may not crop out, but stratigraphic and structural features of the nappes are sufficient evidence for their concealed presence.

Major thrust napppes are not recognized in the early reports by Welsh and James (1961) and Swensen (1975a,b). They assume that the stratigraphy and structures in the Oquirrh Mountains in the vicinity of the Bingham mine are continuous and broken only by an unconformity. Babcock and others (1995) conclude later that thrust faults occur in the range caused by the Jurassic Elko and Cretaceous Sevier Orogenies. These formed "a series of northwest-trending folds south of Bingham and northeast-trending folds north of Bingham with several major thrusts and other complex faulting in the vicinity of the deposit." They too do not recognize a separate Pass Canyon nappe, which is proposed here. This leads to differences in our respective interpretations of the structure of the Oquirrh Mountains.

\section{Location of the Nappes}

The Oquirrh Mountains thrust plates include the Pass Canyon, Bingham, Rogers Canyon, South Mountain, and Fivemile Pass nappes (fig. 6). They were mapped originally on the 7 1/2-minute topographic quadrangles located in figure 1. The Pass Canyon nappe is exposed across the central part of the range north of the Bingham Canyon mine and south of Nelson Peak in the Bingham Canyon 7 1/2-min. quadrangle (Tooker and Roberts, 1988). The Bingham nappe occurs in the southern two-thirds of the range, south of the Bingham Canyon mine. It crops out in the Tooele (Tooker, 1980), Bingham Canyon (Tooker and Roberts, 1988), Lark (Tooker, unpub. data), Stockton (Tooker and Roberts, 1992), Lowe Peak (Tooker, (1992), Tickville Springs (Moore, 1973a), Ophir and Mercur (Tooker, 1987), and Cedar Fort (Tooker, unpub. data) 7 1/2-min. quadrangles. The Rogers Canyon nappe at the north end of the range occurs in the Mills Junction (Tooker and Roberts, 1971a), Farnsworth Peak (formerly Garfield) (Tooker and Roberts, 1971b), Magna (Tooker and Roberts, 1971c), and Bingham Canyon (Tooker and Roberts, 1988) 7 1/2-min. quadrangles. The South Mountain nappe occurs in the Stockton (Tooker and Roberts, 1992) and South Mountain (Tooker, unpub. data) 7 1/2-min. quadrangles. The Fivemile Pass nappe is located north of Fivemile Pass at the very south end of the range in the Mercur 7 1/2-min. quadrangle (Tooker 1987).

\section{Hinterland Source of the Nappes}

The location of a depositional site and hinterland source of sedimentary rocks comprising the nappes near or west of the Utah-Nevada State boundary is inferred in figure 3. The geology of this area is complex structurally and lithologically (Cook, and others 1964; Armstrong, 1972; Wenicke, 1981; Todd, 1983; Miller, 1983; Jordan, 1983; Camilleri and others, 1994, and Miller and Hoisch, 1995). None are able to pinpoint where the sediments were actually laid down because of the overlap of subsequent thrusts and the formation of intervening uplifted core complexes (Compton, 1983). Thus the hinterland area remains a subject of continuing speculation that is beyond the scope of this report.

\section{Movement of the Nappes}

The geologic mechanism for producing decollement thrust faults is still debated, whether it be the gravity model of Rubey and Hubbert (1959), the detachment model of Almandinger and Jordan (1981), or models by Hamilton and Meyers (1966), Armstrong (1972), Roberts and Crittenden (1973), Allmendinger, and others (1983), Price (1989), and DeCelles and others (1995). Parts of the thrust belt are estimated to have been transported eastward toward the present foreland zone as little as $10 \mathrm{~km}$ (Hintze, 1973) to as much $150 \mathrm{~km}$ (Crittenden, 1961). Movement of the thrust belt was irregular, both in time and space (Heller and others, 1986). The Wyoming sector of the thrust belt was emplaced earlier than the Utah sector (Oriel and Armstrong, 1966).

A mechanism for initiating and facilitating nappe movement of Sevier thrust faults also is not fully understood. Some investigators (Roberts and Crittenden, 1973; and Todd, 1983) call upon the gravity model of Ruby and Hubbard (1959). A detachment model described by Allmendinger and Jordan (1981, 1984) envisions a process of upthrusting initiated by an expanding magma chamber in the crust. Cross (1986) proposes the development of a Sevier foreland basin, which facilitates eastward movement of the nappes by gravity. However formed originally, the nappe structures observed in the Oquirrh Mountains part of the foreland are the result of the final burst in movement of the thrust plate and have the appearance of gravity emplacement in their accretion onto the craton platform (Tooker, 1970)

\section{Convergence of Nappes in the Foreland}

The Oquirrh Mountain nappes converged sequentially onto the Uinta trend buttress (figs. 5 and 6). Tooker and Roberts (1988) infer that the Pass Canyon nappe was the first to arrive, followed successively by the Bingham, Rogers Canyon, South Mountain, and Fivemile Pass nappes. The relative timing of nappe emplacements in the Oquirrh Mountains is determined by their placement in the range, their fold structures, degree of refolding, and alteration. 
The directions of fold axes are assumed to be nearly normal to the final direction of nappe movement. The fold systems shown diagrammatically in figure 5 (from Tooker, 1998) indicate that the Pass Canyon nappe (or lobe) moved generally east-northeast to eastward and was folded as it overran the Uinta trend buttress. The northern part of the Bingham nappe, whose folded sedimentary rocks are bent to the northwest, moved northeast overlapping the Pass Canyon plate on the south side of the buttress. However, the main direction of Bingham nappe movement in the southern part of the range is nearly due east. The Rogers Canyon nappe subsequently approached the foreland from the northwest, overlapping the Pass Canyon and Bingham nappes. It moved generally southeast onto the buttress. The South Mountain nappe moved north and north-northeast along the Stockton thrust and overlapped the Bingham plate. Finally, the Fivemile Pass nappe also docked on the Bingham nappe at the south end of the range, having moved in from the south-southwest.

\section{Uplift of the Oquirrh Mountains and Igneous Activity}

Evidence from the types and locations of igneous rock suites and the timing of intrusive and extrusive activity permits inferring that the uplift of the sedimentary rocks overlying parts of the Uinta trend continued during the midTertiary (Oligocene) period of igneous activity (table 1). The sequence of intrusion along the northeast-trending fault system in the Bingham district, developed by Waarnars and others (1978), implies that the faults were reopened successively following intrusion of the composite stocks, and cross cutting dikes. Lateral movement along the faults is not pronounced, which suggests that a vertical component was the main reopening force. A relatively narrow zone of large, nearly comparable-aged monzonite-type stock and dike intrusions in the range overlie a broad Uinta trend zone between the Bingham and Stockton intrusive centers. Volcanic rocks are concentrated along the eastern margin of the range for short distances normal to the zone of uplift. In a general way, the intrusive and extrusive rocks farther from the main zone are progressively younger in age and less abundant.

The Bingham and Last Chance stocks were emplaced early in the sequence (table 1). Moore's (1973b) estimate that the stocks were formed under a sedimentary cover of about 2,300 $\mathrm{m}$ is based on fluid inclusion data. Yet the associated volcanic units, which undoubtedly were formed at or close to the surface, presently lie adjacent to the stocks. One of the possibilities is that uplift of the stocks and erosion of the original sedimentary rock cover brought the intrusives closer to the surface by the time of the formation of the younger volcanic rock south of the main intrusive zone. Late stages of the Oligocene igneous activity were marked by the extrusion of andesitic to latitic volcanic and volcaniclastic rocks in Salt Lake Valley and the
West Transverse Mountains (Smith, 1961; Moore, 1973a). Late-stage hydrothermal solutions developed near the close of intrusive activity were introduced and ore and gangue minerals were precipitated locally in structurally prepared and stratigraphically favorable rocks in and adjoining the intrusives (Moore, 1973c).

The concentration and types of intrusive and extrusive igneous rocks varies in most of the nappes. The Bingham nappe hosts the major intrusive and extrusive center in the range (Tooker and Roberts, 1988). The Rogers Canyon and Fivemile Pass nappes, which lie at the extreme ends of the range show little evidence of igneous activity. The distribution of intrusive ( $\mathrm{Ti}$ ) and extrusive (Tv) rocks, shown later in figures 11 and 12, are summary maps of intrusive rocks in the Oquirrh Mountains from Tooker and Roberts (1998). The petrology and petrography of these rocks are described by Moore (1973b). Additional published studies of these rocks are by Smith (1961), Lanier (1978a), Warnaars and others (1978), Wilson (1978) and Waite and others (1997). Descriptions of them are not repeated here, but their general characteristics and ages are summarized in table 1. The original authors' classifications of rock types are used in this report.

\section{Formation of the Basin and Range Province}

Faults along the eastern edge of the Basin and Range Province (Nolan, 1943) were initiated in the late Cenozoic. They resulted from crustal extension and accompanying magmatism following a period of plate convergence and crustal compression that had produced the Antler and Sevier orogenic events (VonTish and others, 1985). This region is characterized by many normal faults, some of which are still active. Physiographically this is an area of internal drainage.

The present topography of the Basin and Range is that of intermountane alluvial-filled basins and narrow blockfaulted mountain ranges (Gilbert. 1928, Stewart, 1978). The mountain ranges in western Utah and in most of Nevada are surrounded by shallow to deeply filled basins containing clastic sedimentary materials resulting from accelerated uplift and erosion. Some of the graben-like basins flanking the Oquirrh Mountains contain more than 3,600 m of poorly consolidated sediments (Cook and others, 1966). The faults bounding the mountains are believed to be listric, and ranges along the eastern side of the Great Basin, such as the Oquirrh Mountains, have been tilted as much as 10 to 25 degrees to the east (Stewart, 1978; and Melker and Geissman, 1997). Block faulting probably is the result of back-arc uplift and extension developed during the early and middle Cenozoic from diapiric rise and lateral spreading of the North American Plate, which overlay and was heated by a subducted Farallon Plate at depth (Davis, 1979; Stewart, 1978; Eaton, 1979; and Zobach, 1983). The present Oquirrh Mountains are delineated by the Basin and Range event (Gilluly, 1928). 
Table 1. Main types of igneous rocks in the Oquirrh Mountains nappes.

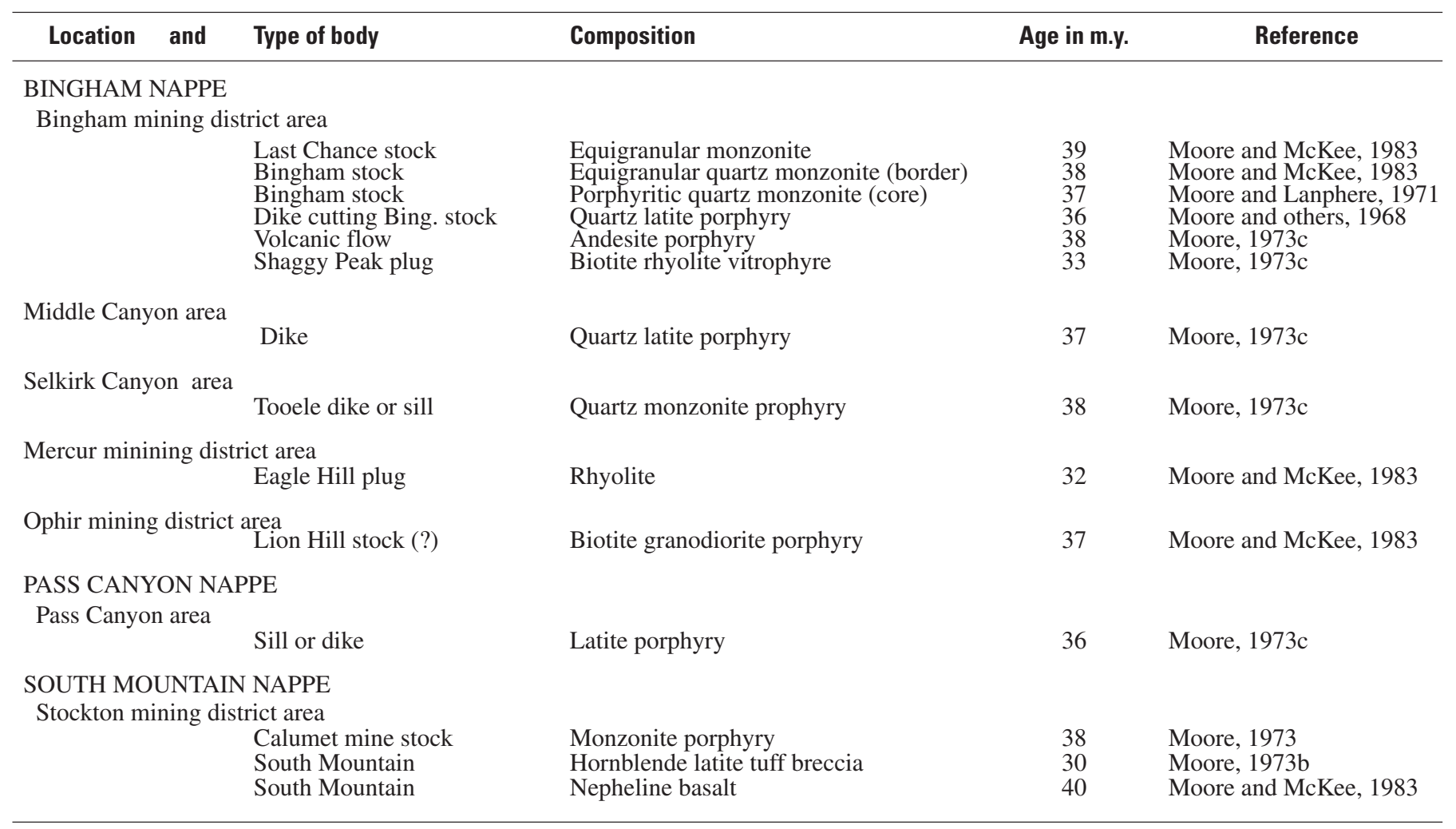

\section{Quaternary Uplift and Pleistocene Glaciation}

Uplift and intense erosion during the early Quaternary unroofed the Oquirrh Mountains and ranges elsewhere in the region. Extensive alluvial fans and pediments were produced along the range fronts, particularly in the central part overlying the Uinta trend zone (Tooker and Roberts, 1971b). These include the Harker Fanglomerate deposits (Slentz, 1955). Although Tooker and Roberts consider that this unit is mainly of Quaternary age, its deposition most probably, in part at least, may be correlated with the Tertiary period of accelerated uplift in the central Oquirrh Mountains.

During the Pleistocene glacial interval, Lake Bonneville, which was a very extensive body of freshwater, occupied the valleys between the ranges (Gilbert, 1886; Eardley and others, 1957; and Crittenden, 1963). The multi-level shorelines mark fluctuating levels of this lake and are the sites of widespread, locally well preserved bars, spits, and other coarse clastic shoreline features. These deposits are most extensive in the areas overlying the Uinta trend.

\section{Geology, Correlation, and Economic Importance of Nappes}

The Oquirrh Mountains stratigraphic and structural data provide new bases for identifying and interpreting the geologic evolution of the Oquirrh Mountains. Until recently, the general physical similarity of Upper Paleozoic stratigraphic units in the central Oquirrh Mountains and the lack of exposures of sole thrust faults has hindered recognition of nappes in the range. Thus, particular emphasis here is placed on published Upper Paleozoic stratigraphy of formations ${ }^{3}$ (Upper Mississippian Chester to Lower Permian Leonard ages) and the folding patterns of these strata. These data are summarized in accompanying tables. More detailed unpublished stratigraphic data are included in the appendix and in cited USGS Open-File reports.

The fold and fault structures in the Oquirrh Mountains, primarily the result of nappe emplacement (Tooker, 1983; Tooker and Roberts, 1988), are summarized on maps of each nappe. Igneous intrusives and the spatially associated ore deposits are located on the leading edges of thrusts that lap onto the Uinta trend buttress. Quaternary clastic deposits skirting the range are not part of nappe structures but were derived in large part from the uplift and erosion of the range and provide direct evidence of continuing local structural activ-

\footnotetext{
${ }^{3}$ Informally named stratigraphic units are indicated where the requirements of the Code of Stratigraphic Nomenclature for naming formations in the Pass Canyon, Rogers Canyon, nappes are not met. New names for some units identified earlier will be required by the code because of geologic name preemptions elsewhere. In such cases, the previously assigned names are identified here for clarity in making comparisons with information presented here.
} 
ity in the part of the nappe that overlies or adjoins the Uinta trend. Sketch maps that highlight or focus attention on specific structural features in the five nappes in the following sections are derived principally from 1:24,000-scale maps by the author and his collaborators, which are updated and summarized in the map of the Range by Tooker and Roberts (1998).

\section{Pass Canyon Nappe}

The Pass Canyon nappe is recognized as a separate entity on the basis of its distinct stratigraphy and structure. It is located in the north-central part of the Oquirrh Mountains, north and northwest of the Bingham mining district (fig. 6). The nappe is composed of the Dry Fork (Pennsylvanian-Permian) and younger Flood Canyon (Permian) units of Tooker and
Roberts (1988). A brief description of the unit's sedimentary rock succession is summarized in table 2. The base and top contacts of the units are faults and their distribution in the range, shown in figure 7, is based on the map of the Bingham Canyon quadrangle (Tooker and Roberts, 1988).

The north side of the Pass Canyon nappe is delimited by the overlying Rogers Canyon nappe (Tooker and Roberts, 1988). The boundary lies partly along the North Oquirrh thrust, which underlies the Rogers Canyon nappe, and partly along the down-dropped, steeply dipping Nelson and Tooele tear or normal faults (fig. 7). The southern boundary of the Pass Canyon nappe is along its join with the overriding Bingham nappe, which is underlain by the (unexposed) sole Midas thrust. This bounding fault is concealed by downdrop along the Pine Canyon, AJ, and Bingham Canyon Faults, which are steep dipping

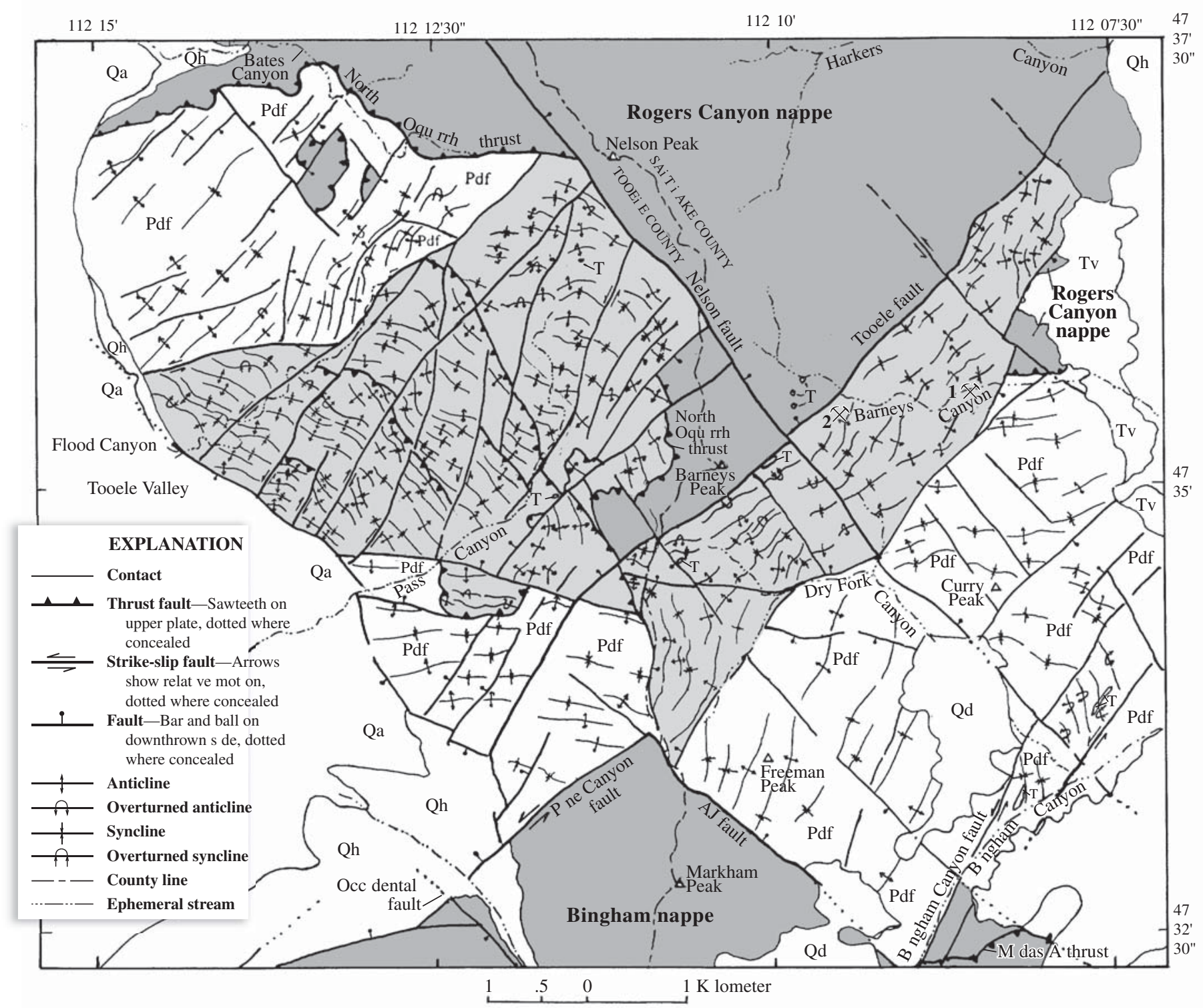

Figure 7. Generalized geologic map of the Pass Canyon nappe showing the main structures and the Dry Fork (Pdf) and Flood Canyon (light shaded) formational units of Tooker and Roberts (1988). The adjoining Rogers Canyon and Bingham nappes are dark shaded. 1, Barneys Canyon mine; 2, Melco mine; Qd, mine dumps; Qh, Harkers Fanglomerate; Qa, alluvium; Tv, volcanic rocks; Ti, intrusive rocks. 
Table 2. Summary of lithology of Paleozoic formations in the Pass Canyon nappe (Tooker and Roberts, 1988).

\begin{tabular}{|c|c|c|c|}
\hline Age & Formation & Thickness & Lithology \\
\hline \multicolumn{4}{|r|}{ Fault } \\
\hline $\begin{array}{l}\text { Permian (Wolf- } \\
\text { camp) }\end{array}$ & $\begin{array}{l}\text { Flood Canyon } \\
\quad \text { unit }\end{array}$ & Not measured & $\begin{array}{l}\text { Shaly-laminated,dark gray upper limestone and arenaceous } \\
\text { limestone, weathers bluish-gray. Superficially resembles } \\
\text { Kirkman Limestone in Wasatch Mtns. (Baker and oth- } \\
\text { ers, 1949). Cliff-forming, interbedded medium to thick } \\
\text { bedded, light gray to brownish-tan calcareous sandstone, } \\
\text { interformational breccia arenaceous limestone and white } \\
\text { calcareous sandstone.Lower part is a thick series of } \\
\text { yellowbrown to reddish-brown-weathering calcareous } \\
\text { sandstone and calcareous quartzite beds }\end{array}$ \\
\hline \multicolumn{4}{|r|}{ Fault } \\
\hline $\begin{array}{l}\text { Permian } \\
\text { (Wolfcamp) } \\
\text { and Upper } \\
\text { Pennsylva- } \\
\text { nian }\end{array}$ & Dry Fork unit & Not measured & $\begin{array}{l}\text { Interbedded thin- to medium-bedded, cross-laminated, light- } \\
\text { brown to tan calcareous sandstone, siltstone, limestone } \\
\text { and chert pebble conglomerate. Weathers light-gray to } \\
\text { tan. Quartzites are poorly sorted sand and silt. Weathers } \\
\text { dark brown to black. Lower part is massive medium- to } \\
\text { thick-bedded, dark brown and tan quartzite and sandstone. } \\
\text { Weathers brown and black. }\end{array}$ \\
\hline \multicolumn{4}{|c|}{ Rogers Canyon thrust fault } \\
\hline
\end{tabular}

normal (south side down). The western side of the Pass Canyon nappe is bounded by range-front normal faults and overlapping Quaternary deposits. The eastern side of the nappe is limited by overlapping Tertiary volcanic rocks, Quaternary alluvial deposits, and Holocene mine waste dumps.

\section{Distinguishing Nappe Stratigraphic and Structural Features}

The nappe is characterized by its intensely faulted strata composed only of sparsely fossiliferous Permian and Upper Pennsylvanian limestone, massive quartzite, sandstone, and conglomerate, and intraformational breccias. These are topped by thin-bedded, laminated blue-gray limestone (table 2 ). The sole thrust underlying the nappe is not exposed. Because these units are delimited and segmented by faults, and their true thickness is as yet not fully known, a complete unfaulted measured section is not available.

\section{Defining Nappe Stratigraphy}

Two informal formational units, the older Dry Fork Pennsylvanian and Permian (?) and younger Flood Canyon Permian(?) units of Tooker and Roberts (1988) are proposed. Their locations in the nappe are shown in figure 7 . The younger Flood Canyon is composed of clastic sediments and contains a thin conglomerate bed and a thick interformational breccia. Poorly sorted brown to tan sedimentary rocks characteristically weather to dark brown and black. One may infer that most of these poorly sorted sedimentary rocks were derived primarily from the western Antler belt rather than the craton.
Dry Fork unit sedimentary rocks are poorly sorted massive to thick interbedded dark brown and tan, composed of highly clastic quartzite and sandstone and thin carbonate beds that weather dark brown to black.

The ages of the units are based on a sparse, poorly preserved Upper Pennsylvanian and Lower Permian brachiopod, bryozoan, and coral fauna in conglomerate pebbles in the upper part of the Dry Fork unit and Wolfcamp fusulinids in siliceous sandstone and black chert layers. The age of Flood Canyon strata is determined mainly from sparse Early Permian (Wolfcamp) fusulinids by Welsh and James (1961).

The presence of conglomerate, breccia, and generally poorly sorted hinterland-type sediments contrast with those that occur in the Bingham nappe. This suggests their derivation primarily from the erosion of an oceanic source area rather than a well-washed and sorted craton sediment source, and their deposition in the hinterland overlying the Uinta trend during a local periodic uplift.

\section{Defining Nappe Structures}

Stratigraphic units are tightly folded, locally asymmetric to overturned, some beds are sheared out. Normal and offsetting tear faults are developed by thrust faults against the buttress. Some folds are refolded locally by the overlapping subsequent Rogers Canyon and Bingham nappes.

A complexly faulted system of folds in the units (fig. 7 ) overlies the Uinta trend buttress. The nappe was moved an unknown distance more or less directly from a west or westsouthwest basin hinterland. In the process of overriding the Uinta trend buttress, the clastic sedimentary rocks in the nappe 
were tightly folded, locally sheared, and imbricate thrust, tear, and normal faults developed. The fold structures in the formations are distinctive. Dry Fork strata are generally thicker and massive, and their folds are asymmetrical, but open. The thinner-bedded, more calcareous strata in the Flood Canyon unit southwest of Nelson Peak are tightly to isoclinally folded and fragmented by faults. The character and intensity of folding in these formational units also depends on their location, whether on or near the uplifted Uinta trend. Massive quartzites, sandstones, and interbedded limestones of the Dry Fork unit wrap around an inferred basement ridge in faulted, tight asymmetrical folds exposed on the northwest side of the upper reaches of Flood Canyon. Southward, these folds are covered by the Flood Canyon unit, which was thrust over them. Farther south of the basement buttress, Dry Fork strata occur in more symmetrical and open folds. These folds trend to the east in an irregular pattern around the flank of the Uinta trend buttress.

Direct evidence for postulating the early arrival of the Pass Canyon nappe is the refolding of isoclinal folds. Sedimentary rocks were redeformed locally by the pressure and drag of the successively overriding Bingham and Rogers Canyon thrust lobes that approached the promontory buttress from nearly opposite directions (fig. 3). Very tight, isoclinally folded Flood Canyon unit beds are overturned to the northeast at the base of Flood Canyon. They are overturned to the southwest in the upper parts of the same fold. Folds in the more massive quartzite-rich beds in the Dry Fork unit on the north side of Flood Canyon are asymmetric and locally overturned to the southeast.

The northern border separating the Pass Canyon and Rogers Canyon nappes on the western slope of the range lies along the moderately north-dipping North Oquirrh thrust, which underlies the Rogers Canyon nappe. The thrust is also exposed in Bates Canyon, locally in the fault block north of Barneys Peak, and in klippen blocks on the prominent ridge south of Bates Canyon (Tooker and Roberts, 1988). The northeast contact of the Pass Canyon nappe with the Rogers Canyon nappe is along the steeply dipping Nelson and Tooele normal faults.

A Pass Canyon (sole) thrust fault is inferred to underlie the Pass Canyon nappe. It is concealed by faults that downdropped Rogers Canyon and Bingham nappes. The amount of movement on the sole thrust may be tens of kilometers while displacements on the imbricate thrusts undoubtedly are a few meters at most. Relatively close-spaced, steep-dipping tear faults cause some folds to be offset small distances. Tear faults of this type lie normal to the fold axes where the folds are tensed by bending into a tight arc as the nappe is dragged against the Uinta trend basement structure.

Numerous steeply dipping normal faults trend northeast and northwest. The northeast-trending faults are the most prominent system within the range. Some of them developed from tension in stressed, arched, and folded strata formed during emplacement of the sole thrust. Later uplift along the Uinta trend and regional Basin and Range extension undoubtedly reactivated and extended earlier-formed normal faults. Offset of stratigraphic units along these faults within the nappe is not large.
The Tooele Valley range-front boundary lies along a series of linked and branching north-northwest- and westnorthwest-trending normal faults that were developed or reactivated during formation of the Basin and Range. They have more substantial vertical displacement than most normal faults in the range.

\section{Concluding Observations About the Nappe}

Several deductions that support the existence of a Pass Canyon nappe are derived from its stratigraphic and structural data. These conclusions differ from those proposed earlier.

(1) Clastic sedimentary rocks are characteristic of the Pass Canyon nappe; they do not occur in the Oquirrh Basin deposits that were deposited south of the Uinta trend. Deposition of thin conglomerate beds and an interformational breccia in the nappe hinterland must have occurred on or close to the Uinta trend. The thick breccias are believed to result from the sloughing of partially lithified fragments coincident with continuing sedimentation that cemented the sloughed fragments during a local limited uplift episode along the Uinta trend. The sedimentary rocks above the breccia include the lower part of Swensen's (1975a) "Kirkman-Diamond Creek Formation." The upper part grades into a limestone that superficially resembles Kirkman Limestone strata in the Wasatch Mountains described by Baker and Crittenden (1961).

(2) Thus, on the basis of its stacking position in the Oquirrh Mountains, its sediment composition, and sparse fauna, the Pass Canyon nappe most resembles the Timpanogos nappe of Baker and others (1949) in the Wasatch Mountains and is believed to be a periferal part detached from that nappe. The Pass Canyon nappe was separated from the Timpanogos nappe along an inferred major east-trending tear fault beneath Salt Lake Valley, and was lodged on the Uinta trend buttress in the Oquirrh Mountains.

(3) There are differences of opinion between Welsh and James (1961) and Swensen (1975a) and this report about the existence of the Pass Canyon nappe.They consider these rocks to be the continuing upper part of the strata exposed in the Bingham mining district. A generalized columnar section showing their Curry, Clinker, and Kirkman formational units is reproduced, in part, in appendix 1. It indicates their interpretation of Permian age sedimentary rocks that occur above an unconformity marked by an initial conglomerate in a thick quartzite portion of their measured section. More recently, Babcock and others (1995, p. 317) interpret these rocks as comprising a folded thrust plate resulting from the Late Jurassic Elko orogeny. However, they still believe that the Curry, Clinker, and Kirkman formational units of Welsh and James (1961) overlie the Bingham Mine Formation (emplaced, according to them, by the Late Cretaceous Sevier orogeny) above a "slight disconformity." 
(4) The author believes that it is now possible to show that significant stratigraphic and structural geological features permit separating the Pass Canyon and Bingham nappes. They originated in separate parts of the sedimentary basin. Their main structures are discordant and their sedimentary rocks exposed in the Oquirrh Mountains are not conformable. The distinctive somewhat clastic Pass Canyon rocks were deposited on or close to a rising part of the Uinta trend. The nappe was moved eastward by the Sevier thrust and ramped directly onto the Uinta trend buttress. In contrast, as will be shown, the Bingham nappe was deposited within the Oquirrh Basin. During the Sevier thrust episode, the northern part of the nappe was deflected tangentally and deformed against the southern side of the Uinta trend in a northeastward glancing drag movement while most of the nappe moved eastward less deformed into a topographic low on the south side of the trend.

\section{Location and Types of Igneous Rocks}

Quartz latite porphyry dikes intrude tightly folded Permian sedimentary rocks in the Pass Canyon nappe. These intrusions are similar in composition to those in the Bingham area. Intrusive rocks are not well exposed in the nappe, and their intermittent distribution is mainly along faults. Only a few isolated, discontinuous, much altered patchy outcrops of porphyry dikes occur on ridge noses in the Pass Canyon nappe (Swensen, 1975a; Tooker and Roberts, 1998). One of these in a tributary of Pass Canyon was dated at 36.5 $\pm 1.1 \mathrm{Ma}$ (Moore, 1973b). Generally the intrusives seem to be spatially associated with the northeast-trending fault systems such as the Tooele Fault (fig. 7). Andesitic dikes(?) and latitic volcanic flow rocks along the edges of the eastern side of the range were also described briefly by Swensen (1975a) but are not dated.

\section{Associated Mineral Resources}

The mineral resources of the Pass Canyon nappe include the disseminated gold deposits in the Barneys Canyon and Melco mine areas. Abundant construction materials, which occur along the margins of the nappe in Tooele and Salt Lake Valleys, are the result of the erosion on the nappe and distribution by Pleistocene lake currents.

\section{The Barneys Canyon and Melco Mine}

Sediment-hosted disseminated gold in the Barneys Canyon and Melco deposits (fig. 7, deposits 1 and 2) also contain minor silver (Gunter and others, 1990; Babcock and others, 1995). These deposits were in an area previously thought to be a less mineralized area $7 \mathrm{~km}$ north of the Bingham center. Jaren Swenson identified the disseminated gold potential of the area in 1980. Exploration followed his collection of a small jasperoid breccia sample that assayed $0.2 \mathrm{oz}$ gold per ton
(Presnell, 1992). The Barneys Canyon mine is currently active. Babcock and others (1995) record its early gold and silver production in table 3.

Gold occurs in altered permeable beds and along imbricate shears in the Barneys Canyon mine (Babcock and others 1995). The deposit occurs mainly in the clastic carbonate sedimentary footwall rocks of the Flood Canyon unit. Fossiliferous limestone of the Grandeur Member of the Park City Formation, which nominally is part of the Rogers Canyon nappe, which was thrust over the Flood Canyon unit, is mineralized near the Barney's Canyon mine. The author believes that the Park City Formation is a down-dropped klippen, part of an imbricate thrust in the upper plate of the North Oquirrh thrust.

Presnell and Parry (1996) conclude that the Barneys Canyon gold deposition is not related to the poorly exposed sparsely distributed intrusive dike(s), which are compositionally similar to the Bingham intrusives of Tertiary age. On the basis of Late Jurassic (K-Ar) ages of illite clays formed in the Permian limestone host rocks, they propose that the gold was leached from the host shales, migrated to sites where it encountered meteoric water in the crests of anticlines, and was deposited. The author concurs with Babcock and others (1995) that the ore deposits at Barneys Canyon are related to those at the Bingham deposit and consider this age problem in a continuing discussion of the Mercur district deposits.

\section{Construction Materials}

Numerous sand and gravel pits that occur in the floor of Tooele Valley represent shoreline beach and bar deposits on successive levels of Quaternary Lake Bonneville. They were derived from erosion of the Range, particularly that part of the range overlying the Uinta trend. Thicker bench deposits of sand and gravel along the eastern and western margins of the Oquirrh Mountains also mark successive lake-level shorelines (Tooker and Roberts, 1971a). These deposits have been extensively mined locally for construction materials for highways, Great Salt Lake shoreline-containment dikes, and for construction of nearby milling, smelting, and refining facilities.

\section{Bingham Nappe}

The Bingham nappe is composed of basin-deposited sedimentary rocks that were folded and faulted in moving eastward on the sole Midas thrust fault (fig. 8). The nappe constitutes the largest thrust plate in the Oquirrh Mountains and its segmented parts extend southward to include the East Tintic Mountains (Tooker, 1983, and Morris, 1983). It is subdivided by major tear faults and changes in sedimentary rock facies southward (Morris and others, 1977; Morris,1983). The Paleozoic stratigraphic section in the Oquirrh Mountains includes lower Paleozoic rocks described originally by Gilluly (1932) and upper Paleozoic rocks reported by Tooker and Roberts (1970) (tables 4 and 5). The stratigraphic section at Tintic, Utah, was described by Morris and Lovering (1961). 
Table 3. Lithology of lower Paleozoic formations in the Bingham nappe (Gilluly, 1932; Gordon and others, 2000).

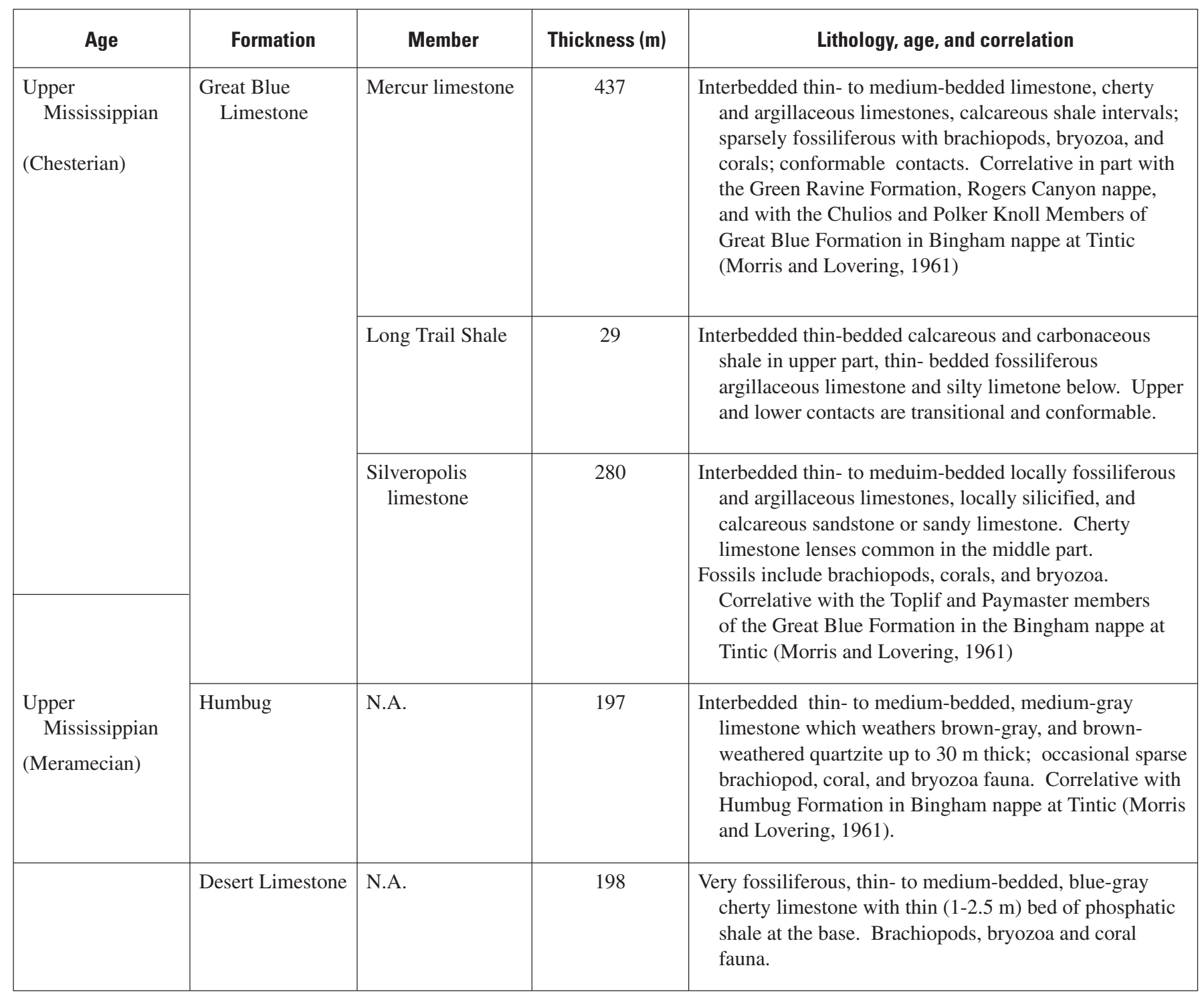

The Oquirrh Mountains portion of the nappe extends from the vicinity of the Bingham mine to the south end of the range (fig. 8). The northern boundary lies along steep normal and tear faults that separate it from the Pass Canyon nappe. The Bingham nappe is overlapped along thrusts from the south-southwest by the structurally and stratigraphically discordant South Mountain and Fivemile Pass nappes and alluvial deposits in Cedar Valley. The western edge of the nappe in Rush Valley lies along intersecting northeast- and northwesttrending range-front normal faults that are overlapped locally by the Harkers Fanglomerate and younger alluvial debris shed off the range. The nappe is overlapped on the east by volcanic rocks and Quaternary gravel deposits.

In the vicinity of the Tintic mining district, the Bingham nappe is overlapped by the Tintic Valley thrust (Morris, 1983).
The northern extension of that same east-directed thrust, east of the Stansbury Mountains, also overlaps the Oquirrh Mountains' Bingham and South Mountain nappes.

\section{Distinguishing Nappe Stratigraphic and Structural Features}

A nearly continuously folded and faulted stratigraphic section, exposed in the central and southern parts of the Oquirrh Mountains, is approximately $8,000 \mathrm{~m}$ thick and contains rocks ranging in age from the Cambrian Tintic Quartzite upwards to an eroded top in the Pennsylvanian Bingham Mine Formation. The main stratigraphic features of the constituent formations are summarized in the 
Table 3. Lithology of lower Paleozoic formations in the Bingham nappe (Gilluly, 1932; Gordon and others, 2000).-Continued

\begin{tabular}{|c|c|c|c|}
\hline Age & Formation & Thickness (m) & Lithology, age, and correlation \\
\hline $\begin{array}{l}\text { Lower } \\
\qquad \text { Mississippian }\end{array}$ & Gardison & 140 & $\begin{array}{l}\text { Very fossiliferous, thin-bedded toward the base, more } \\
\text { massive sandy, and cherty limestones in upper part. } \\
\text { Unconformable lower contact, conformable upper } \\
\text { contact. Correlative with the Gardison Formation, } \\
\text { Bingham nappe at Tintic. }\end{array}$ \\
\hline \multicolumn{4}{|c|}{ Unconformity } \\
\hline $\begin{array}{l}\text { Middle Devonian } \\
\text { (?) }\end{array}$ & $\begin{array}{l}\text { Fitchville and } \\
\text { Pinyon Peak } \\
\text { Limestone, } \\
\text { undivided }\end{array}$ & 56 & $\begin{array}{l}\text { Coarsely crystalline gray dolomite, weathers dark gray, } \\
\text { one massive bed contains conspicuous white calcite } \\
\text { fossil casts. Correlative in part with the Pinyon Peak and } \\
\text { Fitchville Formation at Tintic }\end{array}$ \\
\hline \multicolumn{4}{|c|}{ Unconformity } \\
\hline Upper Cambrian & Lynch Dolomite & $25-305$ & $\begin{array}{l}\text { Thick-bedded, light gray dolomite with some dark-gray } \\
\text { dolomite containing short white rods in the lower part, } \\
\text { and with a few limestone beds in the lower half; is a } \\
\text { prominent cliff-forming unit in Ophir Canyon. The } \\
\text { lower part resembles Bluebird dolomite at Tintic; the } \\
\text { upper part is similar to the Cole Canyon Formation, also } \\
\text { at Tintic (Morris and Lovering, 1961). }\end{array}$ \\
\hline \multirow[t]{3}{*}{ Middle Cambrian } & $\begin{array}{l}\text { Bowman } \\
\text { Limestone }\end{array}$ & 85 & $\begin{array}{l}\text { Mottled shaly limestones, infraformational conglomerate, } \\
\text { and oolitic limestone; a shaly unit about } 11 \mathrm{~m} \text { thick is } \\
\text { at the base. Sparse trilobite fauna. Probably correlated } \\
\text { with Herkimer Limestone at Tintic (Morris and } \\
\text { Lovering, 1961). }\end{array}$ \\
\hline & $\begin{array}{l}\text { Hartman } \\
\text { Limestone }\end{array}$ & 198 & $\begin{array}{l}\text { Banded gray mottled thin-bedded limestone with shale } \\
\text { partings, some oolites toward the top. Sparse trilobite } \\
\text { fauna. Correlated with the lower part of the Teutoinic } \\
\text { Limestone at Tintic (Morris and Lovering, 1961). }\end{array}$ \\
\hline & Ophir Formation & 98 & $\begin{array}{l}\text { Micaceous shale, sandy shale toward the base, contains } \\
\text { several beds of mottled shaly limestone. Brachiopod and } \\
\text { trilobite (Olenellis) fauna. Correlated with the Ophir } \\
\text { Formation at Tintic (Morris and Lovering, 1961). }\end{array}$ \\
\hline Lower Cambrian & Tintic Quartzite & 90 & $\begin{array}{l}\text { Thick-bedded, cross-bedded, white quartzite, which } \\
\text { weathers reddish brown. Becomes shaly toward the top } \\
\text { and grades into the Ophir Formation. Correlated with } \\
\text { the Tintic Quartzite at Tintic (Morris and Lovering, } \\
\text { 1961). }\end{array}$ \\
\hline \multicolumn{4}{|c|}{ Concealed } \\
\hline
\end{tabular}

columnar section, figure 9, and in tables 6 and 7. Individual Bingham nappe formations in the Oquirrh Mountains are described on the basis of geologic maps by Tooker (1980, 1987, and 1992) and Tooker and Roberts (1988 and 1992). Erosion has removed any younger Phanerozoic rocks that may have been present originally overlying the Uinta trend in the Oquirrh Mountains. These rocks are present elsewhere in the southern part of the nappe in the East Tintic Mountains. Precambrian rocks, which underlie the basal Tintic Quartzite elsewhere in this region, are not exposed in the Oquirrh Mountains but may be concealed in the nappe beneath the Tintic Quartzite.

\section{Defining Nappe Stratigraphy}

Sedimentary rocks of the Bingham nappe shown in figure 9 are grouped into (a) those of lower Paleozoic age (Pl), (b) the Manning Canyon Shale (PMm), and (c) upper Paleozoic (Oquirrh Group) strata (Po). Correlations are made with similar-aged rocks within the nappes adjoining the Bingham nappe in the Oquirrh Mountains and the nappe of comparable age in the East Tintic Mountains in order to show the facies changes that occur in the Bingham nappe south of the Uinta trend. Lowest Paleozoic rocks form the base of the stratigraphic section of the nappe in the Oquirrh Mountains. Farther south 


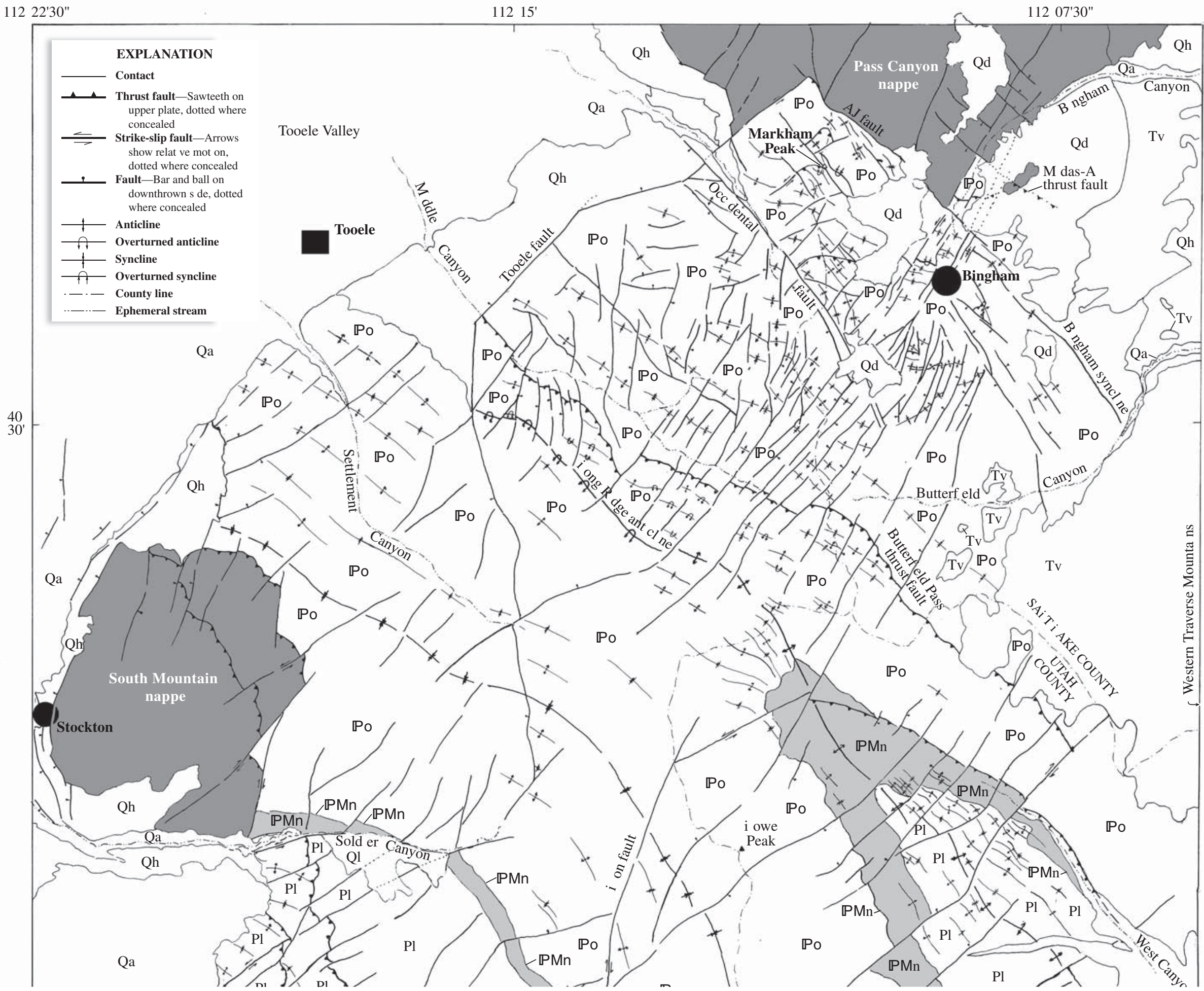




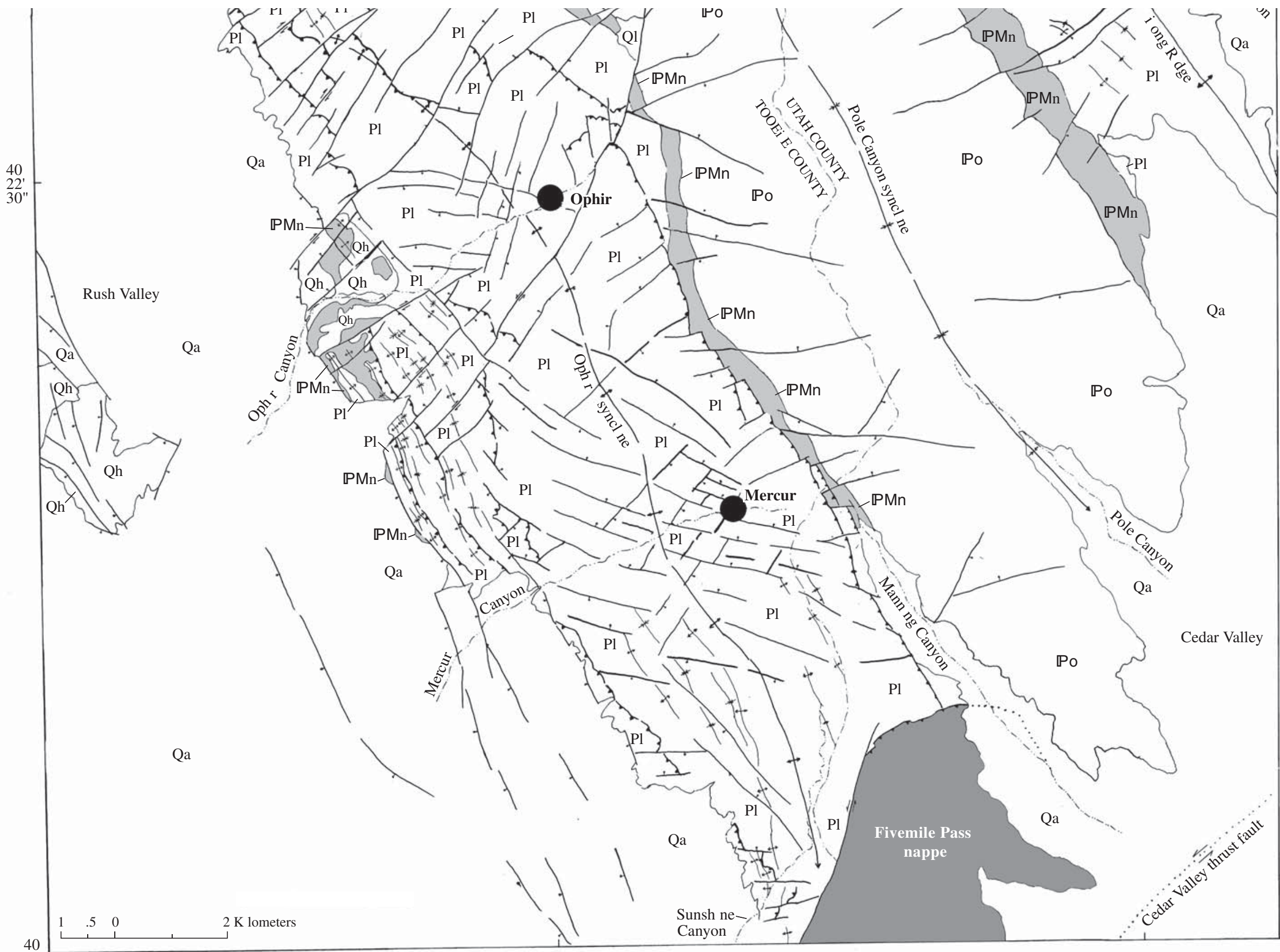

Figure 8. Generalized geologic map of the Bingham nappe showing the distribution of Paleozoic rocks and their major structural features. Main type folds are shown by heavy lines. Adjoining nappes are in dark shading. Typical rocks that define the nappe include PI, Lower Paleozoic Oquirrh Group, PMm, Manning Canyon Shale (light shading); $\mathbb{P}$ o, Upper Paleozoic Oquirrh Group, Qh, Harker Fanglomerate, Od, mine dumps, Qa alluvium, Tv, volcanic rocks. 
Table 4. Lithology of middle and upper Paleozoic formations in the Bingham nappe (Tooker and Roberts, 1970).

\begin{tabular}{|c|c|c|c|c|c|}
\hline Age & Group & Formation & Member & Thickness (m) & Litholoogy and correlation \\
\hline \multicolumn{6}{|c|}{ Unconformity (erosion) } \\
\hline \multirow[t]{2}{*}{$\begin{array}{l}\text { Upper } \\
\text { Pennsylvanian } \\
\text { (Missourian) }\end{array}$} & \multirow[t]{4}{*}{ Oquirrh } & \multirow[t]{2}{*}{$\begin{array}{l}\text { Bingham } \\
\text { Mine }\end{array}$} & $\begin{array}{l}\text { Markham } \\
\text { Peak }\end{array}$ & 1,311 & $\begin{array}{l}\text { Multibedded, intergradational, medium- to thick-bedded } \\
\text { orthoquartzite, calcareous quartzite, calcareous sandstone, } \\
\text { and thin limestone; upper contact is erosional, lower contact } \\
\text { is conformable; sparse fossils include colonial corals, } \\
\text { brachiopods, and fusulinids. Roughly correlative with the } \\
\text { Kessler Canyon Formation in the Rogers Canyon nappe. }\end{array}$ \\
\hline & & & $\begin{array}{l}\text { Clipper } \\
\text { Ridge }\end{array}$ & 910 & $\begin{array}{l}\text { Thick bedded orthoquartzite, calcareous quartzite, calcareous } \\
\text { and quartzose sandstone, and medium interbeds of cherty, } \\
\text { argillaceous and fossiliferous limestones. Two prominent } \\
\text { thick limestone marker beds at the base include the Jordan } \\
\text { and Commercial limestones. Contacts are conformable. } \\
\text { Member is correlative in part with the Kessler Canyon } \\
\text { Formation, Rogers Canyon nappe, and the Salvation unit, } \\
\text { South Mountain nappe (Tooker and Roberts, 1992). }\end{array}$ \\
\hline $\begin{array}{l}\text { Middle } \\
\quad \text { Pennsylvanian } \\
\text { (Desmoinesian) }\end{array}$ & & $\begin{array}{l}\text { Butterfield } \\
\text { Peaks }\end{array}$ & & 2,765 & $\begin{array}{l}\text { Cyclic interlayered thin- to medium-bedded, locally } \\
\text { crossbedded calcareous quartzite, orthoquartzite, and } \\
\text { calcareous sandstone, cherty, fossiliferous, and argillaceous } \\
\text { limestones. Fossils include abundant coral, brachiopod, } \\
\text { and fusulinid fauna. Generally correlative with the Erda } \\
\text { Formation, Rogers Canyon nappe, and the Rush Lake unit, } \\
\text { South Mountain nappe (Tooker and Roberts, 1992). }\end{array}$ \\
\hline $\begin{array}{l}\text { Lower } \\
\text { Pennsylvanian } \\
\text { (Morrowan) }\end{array}$ & & $\begin{array}{l}\text { West } \\
\text { Canyon } \\
\text { Limestone }\end{array}$ & & 442 & $\begin{array}{l}\text { Cyclical thin- to medium-bedded, clastic, arenaceous } \\
\text { limestones, cherty, argillaceous, and dense limestones, } \\
\text { calcareous quartzite, silica-cemented sandstone, generally } \\
\text { banded and crossbedded. Fossils locally abundant include } \\
\text { brachiopods, bryozoans, corals, rare trilobite fragments, } \\
\text { and fusulinids. Correlated with the Lake Point Limestone, } \\
\text { Rogers Canyon nappe. }\end{array}$ \\
\hline $\begin{array}{l}\text { Lower } \\
\text { Pennsylvanian } \\
\text { and Upper } \\
\text { Mississippian } \\
\text { (Chesterian) }\end{array}$ & N.A. & $\begin{array}{l}\text { Manning } \\
\text { Canyon } \\
\text { Shale }\end{array}$ & & 347 & $\begin{array}{l}\text { Predominantly shale with thin interbeds of limestone and } \\
\text { thin- to thick-bedded dark brown quartzite in the lower } \\
\text { half. Grades into dominant limestone in the uppermost part, } \\
\text { transitional into the Oquirrh Group, West Canyon Limestone. } \\
\text { Fossils abundant, include brachiopods, corals, and bryozoans. }\end{array}$ \\
\hline Lower Paleozoic & & & & & See table 3 \\
\hline
\end{tabular}


Table 5. Metal production from the Oquirrh Mountains mining districts.

\begin{tabular}{|c|c|c|c|c|c|c|c|}
\hline & $\begin{array}{c}\mathrm{CU} \\
(000 t)^{*}\end{array}$ & $\begin{array}{c}\text { MO } \\
(000 t)^{*}\end{array}$ & $\begin{array}{c}A U \\
(000 \text { 0z })^{*}\end{array}$ & $\begin{array}{c}\text { AG } \\
(000 \text { oz })^{*}\end{array}$ & $\begin{array}{c}\text { PB } \\
(000 t)^{*}\end{array}$ & $\begin{array}{c}Z N \\
(000 t)^{*}\end{array}$ & $\begin{array}{c}\text { HG } \\
\text { Flasks }\end{array}$ \\
\hline \multicolumn{8}{|l|}{ Bingham } \\
\hline $1863-1972^{1}$ & 11,900 & 360 & 13,253 & $244,413^{4}$ & $2,400^{4}$ & $1004^{4}$ & \\
\hline $1973-1981^{2}$ & 1,670 & $?$ & 3,639 & $?$ & $?$ & \multicolumn{2}{|l|}{$?$} \\
\hline $1982-1990^{3}$ & 551 & 27 & 616 & 811 & & & \\
\hline $1991-1992^{2}$ & 579 & & 973 & 7,679 & & & \\
\hline $1993-1996^{2}$ & 1,217 & & $>516$ & $>8,600$ & & & \\
\hline Total & 15,917 & $>387$ & 18,997 & 261,503 & 2,400 & 1,000 & \\
\hline \multicolumn{8}{|l|}{ Mercur } \\
\hline $1871-1950^{6}$ & 0.2 & & 1,100 & 223 & 1.8 & 0.7 & 3,338 \\
\hline $1983-1990^{7}$ & & & 766.6 & & & & $?$ \\
\hline $1991-1992^{2}$ & & & 248.5 & & & & $?$ \\
\hline $1994-1995^{2}$ & & & 210.1 & & & & \\
\hline $1996-1997^{8}$ & & & 875 & & & & \\
\hline Total & & & 3,200 & & & & $>3,338$ \\
\hline \multicolumn{8}{|c|}{ Ophir and Stockton } \\
\hline $1870-1901^{2 \& 5}$ & 101.5 & & 12 & 50 & 329 & 17 & \\
\hline \multicolumn{8}{|l|}{ Ophir } \\
\hline $1902-1972^{2 \& 5}$ & 4.8 & & 10.6 & 14 & 172 & 46 & \\
\hline \multicolumn{8}{|l|}{ Stockton } \\
\hline $1902-1970^{2 \& 5}$ & 2.9 & & 74 & 11 & 245 & 86 & \\
\hline \multicolumn{8}{|l|}{ Barneys Canyon } \\
\hline $1989-1990^{2}$ & & & 157 & & & & \\
\hline $1991-1992^{2}$ & & & 238 & & & & \\
\hline 1993 & & & 395 & & & & \\
\hline Total & & & 790 & & & & \\
\hline Total Production & $16,026.4$ & $>387$ & $23,017.20$ & 253,201 & $3,147.80$ & $1,149.70$ & $>3,338$ \\
\hline
\end{tabular}

*Thousand tons; thousand ounces

${ }^{1}$ James (1978).

${ }^{2}$ USGS (1883-1923, 1995-1996) and USBM (1924-1994).

${ }^{3}$ British Petroleum Co. (1986) and USBM (*1924-1993).

${ }^{4}$ The UV Industries closed the Lark and U.S. Mines underground workings in 1970, ending the main production of silver, lead, and zinc ores (Tooker, 1990).

${ }^{5}$ Stowe (1975).

${ }^{6}$ Kornze and others (1985).

${ }^{7}$ Shrier, American Barrick (1993, verbal commun.).

${ }^{8} \operatorname{Kerr}(1997)$. 


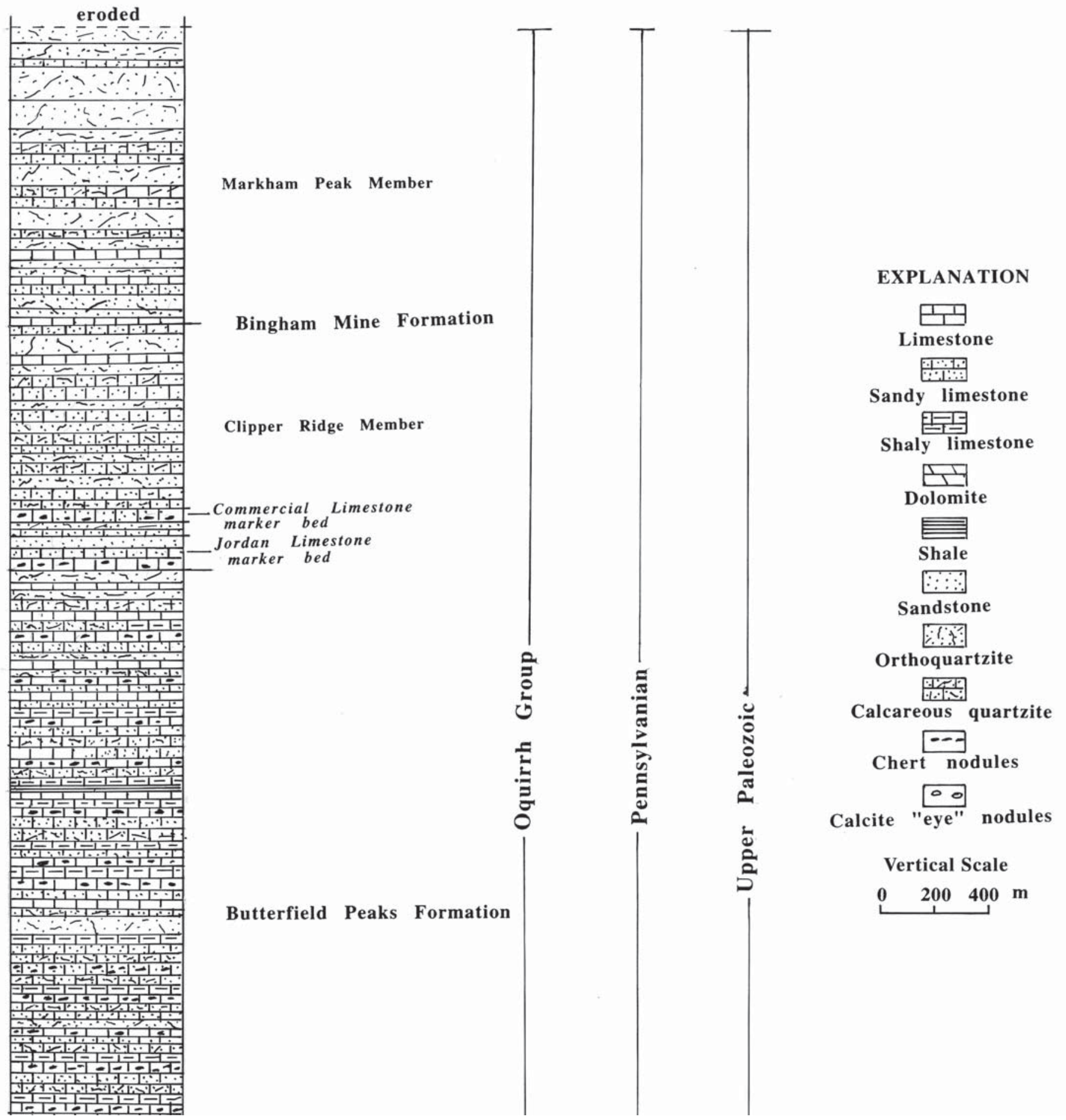




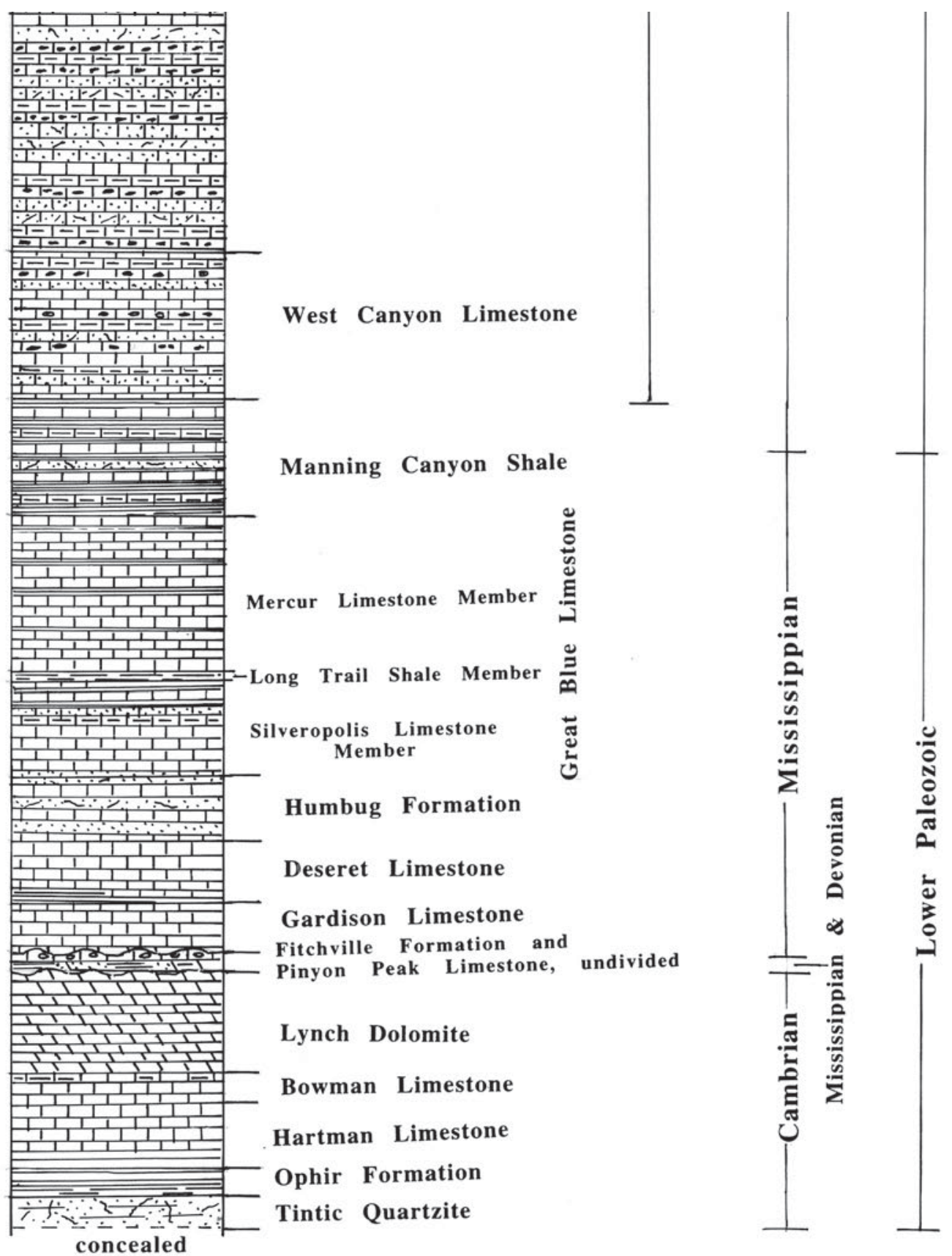

Figure 9. Generalized columnar section of lower and upper Paleozoic formations in the Bingham nappe. 
at Tintic, Utah, the upper part of the Precambrian Big Cottonwood Formation is included in the base of the Bingham nappe.

Bingham nappe rocks were deposited in a continually sinking Oquirrh Basin. They are generally well sorted and composed of rounded clean sand grains. The limestones are very fossiliferous in the Oquirrh and East Tintic Mountains sections. This is in contrast with the Timpanogos nappe, in which Baker and Crittenden (1961) reported a generally less abundant fossil fauna. The Lower Paleozoic stratigraphic section is 2,812 $\mathrm{m}$ thick in the Oquirrh Mountains and was originally described by Gilluly (1932). The formations shown in table 4 range from Cambrian quartzite to Mississippian limestone. They crop out mainly in the core of the Ophir anticline and eastern part of the Long Ridge anticline in the southern Oquirrh Mountains (fig. 8).

Correlations with the East Tintic stratigraphy, based on the work of Morris and Lovering (1961), demonstrate changes in facies southward in the Bingham nappe. The Tintic Quartzite at Tintic is almost eight times thicker than its $9 \mathrm{~m}$ counterpart in the Oquirrh Mountains. At Tintic the formation is underlain conformably by the Precambrian Big Cottonwood Formation. Thinning of the unit in the Oquirrh Mountains may be due to a lack of deposition, its bypass across the Uinta trend, or more likely, its exclusion by the sole Midas thrust.

There are no formations in the Oquirrh Mountains correlative with the more than 1,500 m of Upper Cambrian, Lower Ordovician, Silurian, and Lower Devonian carbonate rocks at Tintic. There are no clastic deposits peripheral to the trend due to the erosion of them, if they once were present in the Oquirrh Mountains. These sediments bypassed the northern part of the Oquirrh Basin because of the uplifted Uinta trend. The succeeding Upper Devonian Fitchville Formation is present in the Oquirrh Mountains but is much thinned in comparison with the serction at Tintic. One of the characteristic massive gray marker limestones in the Fitchville, called the "eye bed" for its large calcite blebs, occurs in both localities.

The Upper Mississippian Great Blue Limestone in the Oquirrh and East Tintic Mountains are of comparable composition and thickness, but the upper members of the formation at Tintic are those of a very shaly "starved basin" composition in comparison with limestone strata of the same age in the Oquirrh Mountains.

Manning Canyon Shale is shown as a separate formation on figure 8 to mark a prominant topographic break and the boundary between the lower and upper Paleozoic rocks in the Oquirrh Mountains. The formation is $347 \mathrm{~m}$ thick and Upper Mississippian and Lower Pennsylvanian in age. Its lithology, described in table 5, is similar to that at Tintic.

Upper Paleozoic sedimentary rocks in the Bingham nappe consist of three Oquirrh Group formations, 5,177 m thick, that crop out as broad north- to north-northwest-trending folds (fig. 8) in the higher northern and eastern parts of the Oquirrh Mountains. The type localities of the constituent formations described by Tooker and Roberts (1970) are in the north central Oquirrh Mountains, near the Bingham mining district.
The formations conformably overlie the Manning Canyon Shale. Gilluly (1932) originally named these rocks the Oquirrh Formation. They are now redesignated the Oquirrh Group by Welsh and James (1961). It includes three formations, the Lower Pennsylvanian (Morrow) West Canyon Limestone, the Middle Pennsylvanian (Desmoines) Butterfield Peaks Formation, and Upper Pennsylvanian (Missouri-Virgil) Bingham Mine Formation, which is subdivided into Clipper Ridge and Markham Peak Members (Nygreen, 1958; Tooker and Roberts, 1970). They are described briefly in table 3 . Their paleontologic ages and regional correlations are discussed by Gordon, and Duncan (1970).

The stratigraphic section of the Bingham nappe in the Oquirrh Mountains is nearly 2,000 m thicker than at Tintic. The 442-m-thick West Canyon Limestone is composed of cyclic repetitions of thin-to-medium bedded very fossiliferous arenaceous, bioclastic, cherty, densely crystalline and argillaceous limestones and thin calcareous quaretzite beds. Conformably overlying it is the 2,765-m-thick Butterfied Peaks Formation. It is also cyclically bedded. A more siliceous (that is, orthoquartzite, calcareous quartzite and sandstone) regime of sedimentary rocks begins with the Clipper Ridge Member of the Bingham Mine Formation. The limestones are interbedded with quartzite beds 46 to$91 \mathrm{~m}$ thick. Cyclic fossiliferous limestone and calcareous quartzite marker beds at the base include the $110 \mathrm{~m}$ Jordan and the $41 \mathrm{~m}$ Commercial Limestone beds, which are the main units replaced by base and precious metal deposits in the Bingham Mining District. Similar-aged (Clipper Ridge) rocks at Tintic are $975 \mathrm{~m}$ thick and are predominantly limestones. The Markham Peak Member is composed mainly of thick-bedded to massive orthoquartzite and calcareous quartzite, sandstone, and siltstone. A few interbedded thin, 0.3 to $1 \mathrm{~m}$, fusulinid bearing arenaceous limestones are also replaced by the sulfide ores in the district (Rubright and Hart, 1968, Atkinson and Einaudi, 1978). The Bingham Mine Formation is composed of well-sorted, clean quartrzitic beds that weather tan to light brown in contrast with dark brown to black weathering rocks in the adjoining Pass Canyon nappe.

Gordon and Duncan (1970) do not identify Lower Permian fossils in the Oquirrh part of the Bingham nappe. Permian ages reported for the upper parts of the stratigraphic section by Welsh and James (1961) are based on rocks that Tooker and Roberts (1988) now include in the Pass Canyon nappe on the basis of its mapped structural and stratigraphic features. If Permian rocks overlay the Pennsylvanian rocks now exposed in the northern end of the Bingham nappe in the Bingham district, they most probably were eroded during subsequent periodic Tertiary uplift of the Uinta trend in that area.

Morris and Lovering (1961) report that post-Oquirrh Group Paleozoic rocks in the southern East Tintic Mountains overlie the group disconformably and include the 209-m-thick (Leonard) Diamond Creek Sandstone and 494-m-thick (Leonard-Guadalupe) Park City Formation. 


\section{Defining Nappe Structures}

Distinctive Oquirrh Mountains main and secondary folds and sole, imbricate, tear and normal fault structures (fig. 8), were derived primarily from emplacement of the nappe. They are principally the result of differences in the relative competence of the rock strata, their locations on or peripheral to the basement Uinta trend buttress, and their proximity to the leading edges of sole and (or) imbricate thrusts. The Bingham nappe was folded as it moved east, east-northeast to northeastward on the sole Midas thrust fault. The northern part of the nappe moved tangentally onto the Uinta trend buttress and the previously docked Pass Canyon nappe. The nappe was stratigraphically and structurally thinned northeastward by the Midas thrust as it rose against the trend. Tightly folded and sheared upper Oquirrh Group strata occur along the lead edge of the nappe at Bingham, whereas a few kilometers to the southwest at Ophir, the complete stratigraphic section includes Cambrian Tintic Quartzite at its base (Tooker, 1992). Through-going main folds are the most prominent structures in the range, but locally they are paralleled on the upper plates of imbricate thrusts in the nappe by secondary folds of more limited length. Thrust, tear, and normal faults comprise the main fault structures in the range. They may be reactivated locally by subsequent extensional tectonics.

Two principal types of folds are main (named) and secondary folds in figure 8 . The main folds on the upper plate of the Midas thrust fault are composed of thick, massive, and competent strata of the upper Paleozoic Oquirrh Group. Through-going Long Ridge and Ophir Anticlines are flanked by the Pole Canyon and Bingham Synclines. Except for the Ophir Anticline, which is described later, these folds form the high backbone of the range and are broad, of high amplitude, and generally north-northwest-trending structures. They bend to the northwest at their northern ends where the thrust-thinned stratigraphic section at the leading edge of the thrust fault impinges tangentially on the Uinta trend buttress. They are asymmetrically and locally overturned to the northeast and are terminated at the Tooele Valley range front by normal faults and unconsolidated sediments. The folds are overlapped at the south end by the South Mountain and Fivemile Pass thrusts.

Smaller-amplitude, tightly folded, and locally overturned secondary folds, commonly segmented by tear faults, occur along the thinned leading edges of imbricate thrusts within the Bingham nappe. These include folds above several small imbricate thrusts of the upper plate of the concealed sole Midas thrust in the Bingham mining district (fig. 10). Those above the longer Butterfield Pass and West Canyon imbricate thrusts southwest of Bingham, and those on the upper plate of the Manning thrust along the western range-front of the Oquirrh Mountains (fig. 8).

The Bingham (main) Syncline and its associated secondary folds in the Bingham mining district (fig. 10) provide clues to complex sedimentary rock structures along the leading edge of the Midas thrust as it was moved toward the uplifted Uinta trend buttress. However, these structures are largely obscured by the extensive intrusive stocks, dikes, and open pit mine waste dumps (Tooker and Roberts, 1998). On Markham Peak the Bingham Syncline is asymmetrical and locally overturned to the northeast. Secondary folds formed above imbricate thrusts associated with this main fold are also asymmetrical and overturned (Einaudi, 1975, Tooker, 1998, fig 8). Numerous low amplitude secondary folds occur in the zone between the Bingham Canyon and Main Hill Faults on the western side of the Bingham mine. They are closely spaced, jammed together, and overturned to the north. One may surmise that these folds also are on the upper plate of yet another imbricate thrust. A concentration of secondary folds occurs in the area between the Bingham and Last Chance stocks. Apparently these folds also were formed on the upper plate of an imbricate thrust.

East of the northeast trending Main Hill (tear) Fault, the continuing eastern part of the Bingham Syncline is offset northward and is an open, nearly symmetrically shaped fold trending southeastward away from the Uinta trend. South of the open pit mine, and east of the northwest trending Galena Chief Fault, the Galena Gulch folds clearly intersect the open part of the Bingham Syncline in structural unconformity.

South of the area impacted by the Uinta trend, the structure of the Long Ridge Anticline and Pole Canyon Syncline are continuous to the south end of the range. The Long Ridge (main) Anticline is tightly folded and overturned locally at its western end overlying the trend near Tooele, but it broadens on the eastern side of the range along Long Ridge in West Canyon. The anticline contains numerous secondary folds on its northern flank, which is the upper plate of the imbricate West Canyon thrust. The Pole Canyon Syncline includes the highest points of the Oquirrh Mountains and is composed of very competent upper Oquirrh Group formations. The syncline is symmetrical for most of its length. Flanking secondary folds of the Pole Canyon Syncline are wide-spaced, broad open folds. No associated imbricate thrust faults occur in this fold.

The Ophir Anticline is on the lower elevation western side of the southern Oquirrh Mountains (Tooker and Roberts, 1998) and generally is parallel or subparallel to the other main folds in the range. It crops out along the low ridge west of Manning Canyon and the south fork of Ophir Canyon. In contrast with the northeastern main folds, composed of upper Paleozoic Oquirrh Group sedimentary rocks, the Ophir Anticline is composed of Cambrian to Mississippian sedimentary rocks. The stratigraphic section consists of interbedded thin- and medium-bedded carbonates, shaly limestone, and quartzose sedimentary rocks (sheet 3 of Tooker 1987). These abundant, thin-bedded argillaceous limestone and shale units are less competent than the thicker siliceous beds that constitute the upper Oquirrh Group.

The Ophir Anticline is located in the upper plate of the Manning thrust, an upper imbrication of the Bingham nappe that probably moved only a moderate distance eastward to overlap the west side of the Pole Canyon syncline east of Mercur. The Ophir fold trends sinuously southeastward. The fold 


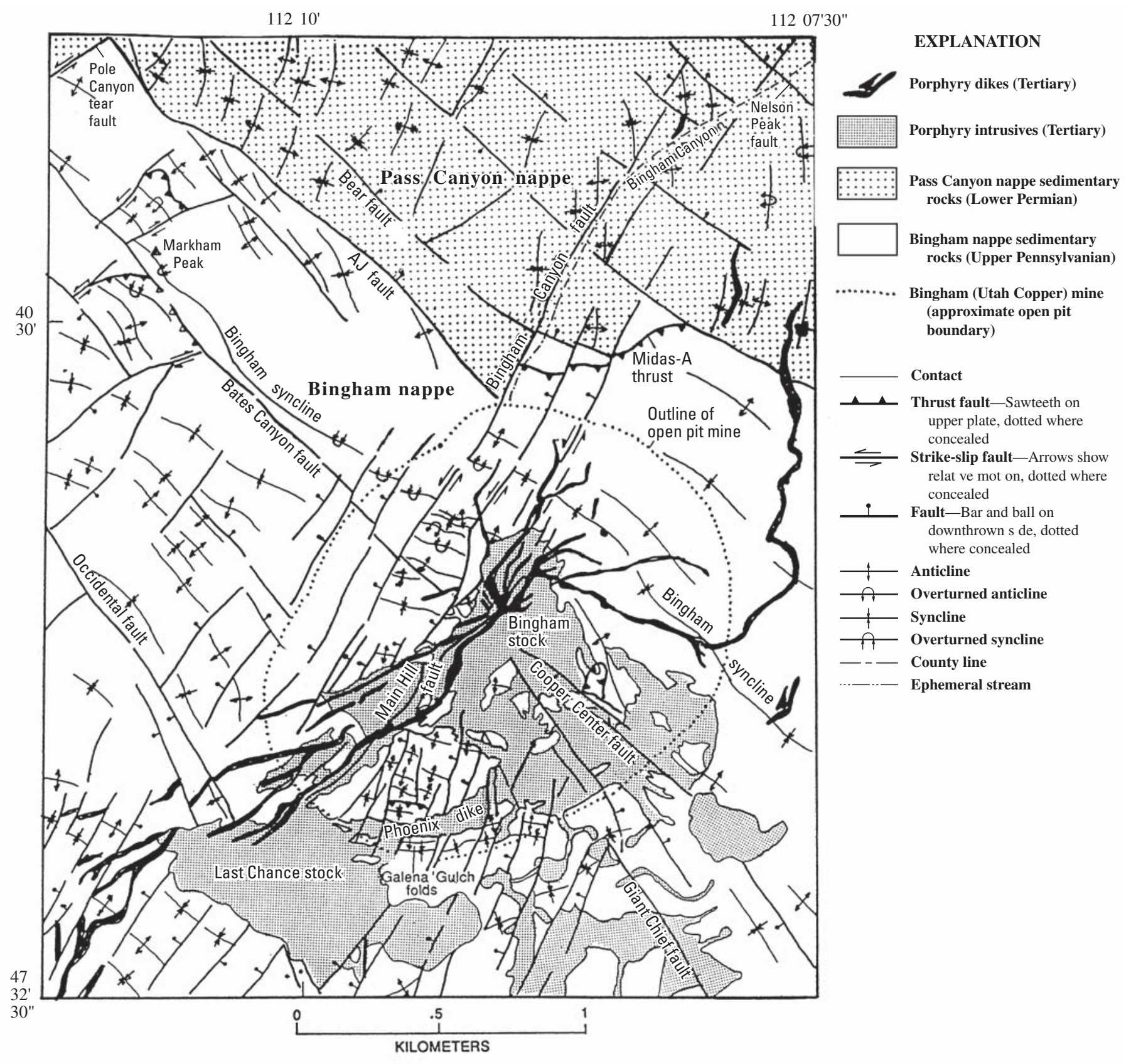

Figure 10. Principal Bingham nappe fold and fault structures of the in the Bingham mining district, Utah (from Tooker and Roberts, 1988). Outline of the open pit mine is dotted. Tertiary stocks (shaded) and northeast-trending Tertiary dikes (solid) intrude the northwest trending folded and faulted undivided Markham Peak and Clipper Ridge Members of the Bingham Mine Formation and the Butterfield Peaks Formation (Tooker and Roberts, 1970). Contact of the Bingham nappe and older Pass Canyon nappe (stippled) lies along the steep-dipping A.J. fault; the underlying Midas sole thrust of the Bingham nappe is concealed. 
is concealed by local imbricate thrusts at its northern end at the western range front. The anticline is terminated by normal faults along Tooele Valley range front. The southernmost end of the Ophir fold plunges to the south and is overlapped by the Fivemile Pass nappe. In between these terminal parts of the fold, the symmetry of the anticline changes south of Ophir Canyon and the Lion Fault.

North of the tear fault, as seen on the north wall of Ophir Canyon (cross section A'-A", in Tooker, 1987), the Ophir fold is a high amplitude, nearly symmetrical structure, exposing the complete Lower Paleozoic stratigraphic section. North of Ophir Canyon, and closer to the underlying Uinta trend, the range is topography higher, more rugged (Tooker and Roberts, 1992). Gently folded, steeply dipping imbricate thrusts on the western flank of the Ophir anticline (in the Dry Canyon area on the ridge northwest of Ophir) emplace lower Mississippian carbonate formations over younger Great Blue Limestone. Small subparallel secondary folds were developed in the overriding strata (Tooker, 1998).

South of the Lion tear fault, the Ophir fold is an asymmetrical, flatter, broader, much faulted arc (cross-section B'-B"' in Tooker, 1987). Locally, east of Mercur at the head of Manning Canyon, the eastern limb of the Ophir Anticline becomes steeply east dipping to nearly vertical. The Great Blue Limestone is overturned and is thrust over the younger Manning Canyon Shale. The western side of the Ophir Anticline (and the range) consists of gently west-dipping slopes that contain several imbricate thrusts overlain by a series of close-spaced, low-amplitude secondary folds.

The Bingham nappe contains a number of additional imbricate thrust faults as well as those already mentioned in the Bingham district. Some are tracaeable for long distances across the range, but of generally relatively small stratigraphic displacement. In general, movement on these lesser thrusts is much smaller than that along the Midas thrust. The Butterfield Pass and West Canyon imbricate thrust faults lie en-echelon along the locally asymmetrical Long Ridge Anticline. The West Canyon thrust ramps Manning Canyon Shale over the younger West Canyon Limestone.

The Manning thrust underlies Lower Paleozoic formations that constitute the broad, flattened Ophir Anticline. The thrust locally places older Great Blue Limestone strata over the Manning Canyon Shale east of Mercur. Small imbricate thrusts on the southwest limb of the Ophir Anticline west of Mercur consist mainly of a series of small displacements of the Silveropolis limestone, probably along the Long Trail Shale beds, over the upper Mercur limestone members of the Great Blue Limestone.

Thrust, tear, and normal faults are shown in figure 8 . The sole Midas thrust may be exposed underground in the workings of the North skarn-ore deposit in Bingham Canyon (Shrier, oral communication, 1989). One may also infer its presence from the cross-sections by Babcock and others (1995) in their figure 7. They show complexly faulted overturned folds of the Jordan and Commercial marker beds at depth, north of the Bingham mine.
Although the sole Midas thrust is now known not to be exposed in the Oquirrh Mountains, an upper imbricate strand at Bingham was named "Midas" by James and others (1961a). It is here renamed the Midas-A Fault to avoid confusion ${ }^{4}$. They correctly indicates that that thrust has no great regional consequence.

Tension produced in arched folds caused by oblique ramping of the nappe against the Uinta buttress, as at Bingham, promoted the formation of prominent, close-spaced, steep-dipping, northeast-trending tear faults normal to the fold axes. These tear faults segmented the secondary folds, locally and facilitated the irregular displacement of fold axes forward for short distances, as seen in the Bingham mine area (fig. 10; Tooker and Roberts, 1988).

Normal faults in the range are steeply dipping, generally northeast- and northwest-trending structures. They have only modest movement within the range in terms of offset formations, but have much greater vertical displacement along the range borders and in the valleys beyond. Normal faults are more abundant in the thin- to medium-bedded Mississippian limestones and shales exposed on the upper plate of the Manning thrust (fig. 9). At Ophir Canyon, the faults trend northwestward, but the trend shifts southward to the west-northwest in the Mercur Canyon area. This change of the fault trend, which is coincident with the bending in the Ophir fold, is considered to result from thrust tectonics in thin, less competent strata on the upper plate of the Manning thrust. The western margin of the Oquirrh Mountains is defined by progressive down drop to the west along the systems of normal faults forming extensive thin-covered pediments, such as occurs between Ophir and Mercur Canyons. Constituent formational units are not greatly offset.

\section{Location and Types of Igneous Rocks}

The Bingham nappe contains the most and greatest variety of intrusive and extrusive rocks in the range (table 1). The Bingham mine area is the major center of intrusive and extrusive activity, followed by progressively lesser intrusive activity occurring outbound in the Middle Canyon-Soldier Creek area, the Lion Hill-Porphyry Knob and the Mercur-Ophir mining areas (figs. 11 and 12).

\section{Bingham Mining District Area}

Igneous activity in the Oquirrh Mountains began with the formation of intrusive stocks, sills, and dikes and ended with extrusive volcanic flows (Lasnier and others, 1978c; Bray, 1969; Moore and others, 1968; and Babcock and others, 1995. The areal distribution, isotopic ages, and chemical and physical properties of igneous rocks, which follow, are based on reports by Moore and Lanphere (1971), Moore (1973b, 1973c), Bray and others (1975), Moore (1978), Lanier and others (1978a,1978b),

\footnotetext{
${ }^{4}$ Here named the Midas-A (imbricate thrust) Fault, as shown in figures, to avoid confusion with the sole Midas thrust in this and other reports.
} 


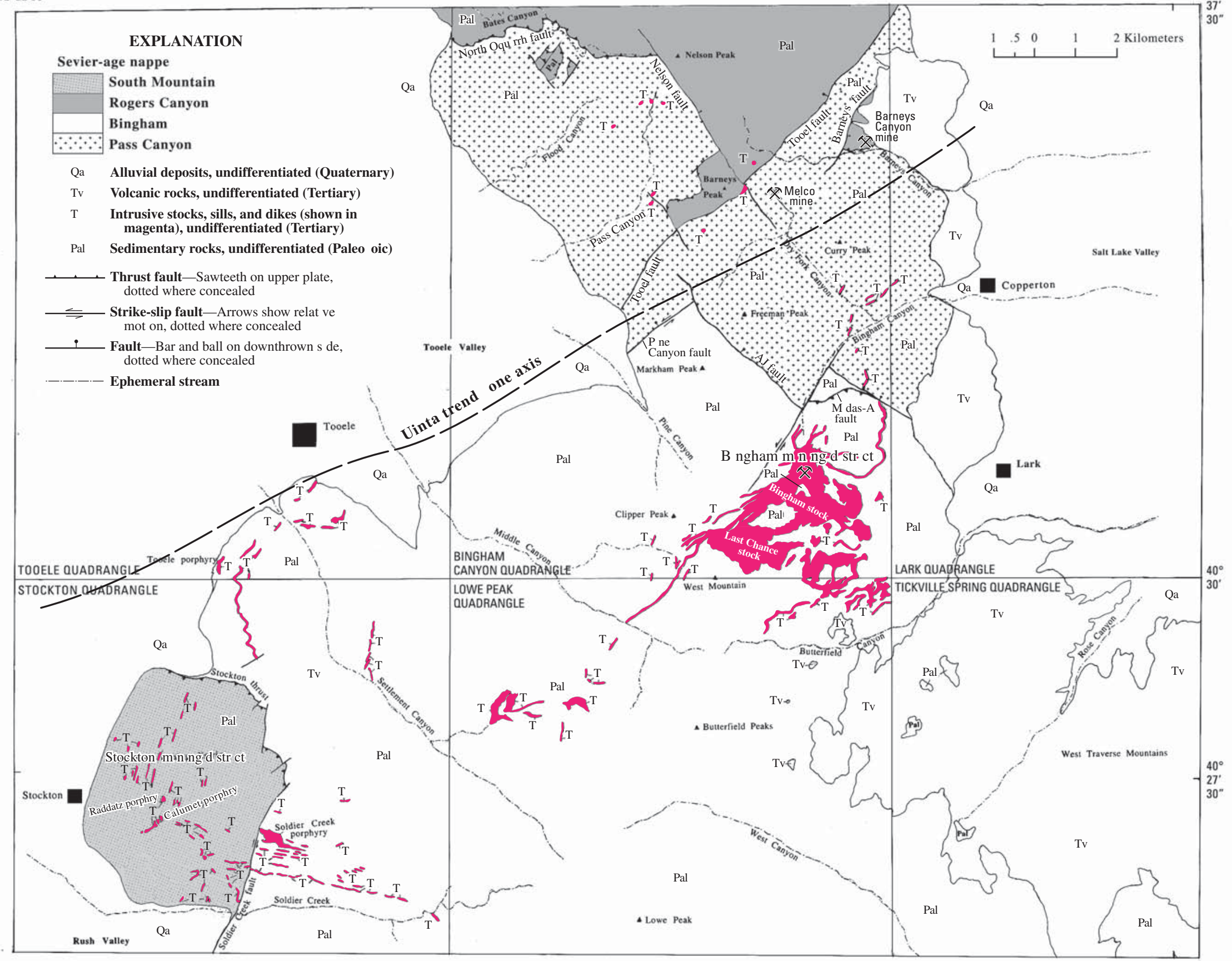

Figure 11. Generalized geologic map showing the distribution of the main bodies of igneous intrusive and extrusive rocks (shown in magenta) in the Pass Canyon, northern Bingham and South Mountain nappes in the Oquirrh Mountains, Utah. The trace of the Uinta trend axis is shown. 


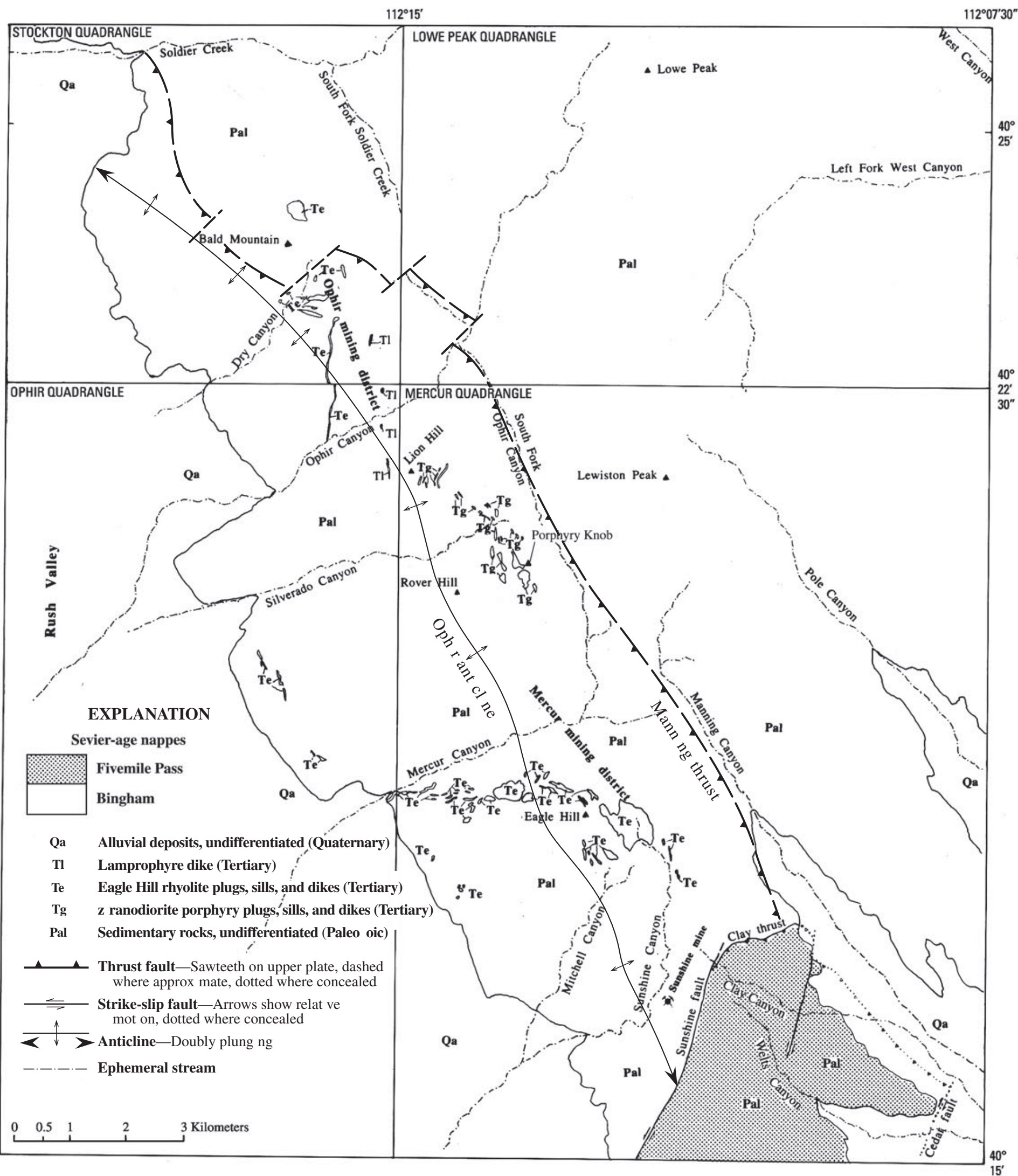

Figure 12. Generalized map showing the distribution of Bingham nappe intrusive igneous rocks in the vicinity of the Ophir and Mercur mining districts. The locations of the Manning thrust and Ophir Anticline are shown. 
Swensen (1975a), Warnaars and others (1978), Bowman and others (1987), and Babcock and others $(1995,1997)$.

The Last Chance and Bingham stocks (fig. 11), which are now known to be interconnected at depth (Lanier, and others, 1978a), are composed of an early equigranular monzonite phase, beginning at about $39.8 \pm 0.4 \mathrm{Ma}$. Quartz monzonite porphyry was intruded along the northwestern border of the Bingham stock, beginning at about $38 \mathrm{Ma}($ ?). The rocks are intrusive into the Clipper Ridge and Markham Peak Members of the Bingham Mine Formation and underlying Butterfield Peaks Formation.

These formations are cut by later latite and quartz latite dikes and plugs (about $37.7 \pm 0.5 \mathrm{Ma}$ in age), and subsequently intruded by quartz latite porphyry dikes and plugs. An intrusive porphyritic latite sill (about $36.9 \pm 1.0 \mathrm{Ma}$ ) crops out southeast of Lark, Utah. Northeast-trending latite dikes along the range front between the mouth of Barneys Canyon and Lark may be about the same age.

Several pebble dikes and breccia pipes as much as $180 \mathrm{~m}$ diameter and as much as $910 \mathrm{~m}$ in vertical extent seem to be closely associated with latite intrusives south and east of the Bingham stock (Rubright and Hart, 1968; Moore, 1973a,b). These bodies suggest that latitic melts became fluid-saturated and overpressured and were released by explosive forces.

Extrusive, mostly latitic volcanic rocks overlie sediments of the Butterfield Peaks Formation mainly south and southeast of the Bingham district. Armstrong (1970) reports an age of $38.8 \pm 0.9 \mathrm{Ma}$ for andesite porphyry flows along the eastern range front north of the mouth of Bingham Canyon, but Warnaars and others (1978) question this age determination. Laharic deposits (or breccias) as much as $450 \mathrm{~m}$ to 610 $\mathrm{m}$ thick, composed of varieties of latite, make up a basal unit south of Bingham Canyon. These are interbedded with waterlaid tuff, volcanic conglomerate, and crossbedded sandstone. The breccias are overlain by lenticular latitic flows, which may be as much as $250 \mathrm{~m}$ thick. Rhyolite vitrophyre flows and flow breccias form sizable bodies southeast of Bingham in the Tickville Springs quadrangle. Moore (1973b) dates these rocks at $31.2 \pm 0.9 \mathrm{Ma}$. The volcanic rocks are intruded by the Shaggy Peak rhyolite stock that is dated at 33.0 Ma. Patches of monolithologic latite tuff-breccias, the youngest volcanic rocks (30.7 $\pm 0.9 \mathrm{Ma})$, cap this series of flows (Moore, 1973b).

\section{Middle Canyon-Soldier Creek Areas}

The northwestern part of the Bingham nappe between Middle Canyon and Soldier Creek contains several dikes and plugs that cut sedimentary rocks of the Oquirrh Group (fig. 11). These are described by Gilluly (1932) and by Tooker and Roberts (1988 and 1992) with age dates by Moore (1973c), Warnaars and others (1978), and Moore and McKee (1983). A 3 to 4 m-thick latite porphyry dike, which intrudes the Butterfield Peaks Formation, crosses Middle Canyon southwest of the Bingham mining district, and is a continuation of the southwest-trending swarm of dikes in the southwestern part of that district. The latite dike is dated at $37.8 \pm 1.1 \mathrm{Ma}$. A 3- m-thick quartz monzonite porphyry sill intrudes the Markham Peak Member of the Bingham Mine Formation at the range front south of Tooele, Utah. A thinner sill of comparable composition intrudes the Butterfield Peaks Formation on the northern slope of Settlement Canyon, opposite the mouth of Dry Fork. The age of the Tooele sill is $38.6 \pm 1.1 \mathrm{Ma}$; the age of the Settlement Canyon body is as yet unknown. The quartz monzonite stock and associated quartz monzonite porphyry, diorite, and diorite porphyry sills on the north side of Soldier Creek occur in the lower part of the Butterfield Peaks Formation and were not dated. Diorite and diorite porphyry stocks, dikes, and plugs, which occur at the heads of the East Fork of Settlement Canyon and White Pine Canyon, also intrude the Butterfield Peaks Formation; no age was determined for them.

\section{Lion Hill and Porphyry Knob Areas}

Faulted altered biotite granodiorite porphyry plugs and associated sill and dikes occur in and along the Long Trail Shale Member of the Great Blue Limestone on the eastern flank of the Ophir anticline (see fig. 12, and Gilluly, 1932). The rocks are age-dated by Moore and McKee (1983) at $36.7 \pm 0.5 \mathrm{Ma}$.

\section{Ophir and Mercur Mining District Areas}

The Eagle Hill rhyolite porphyry, named from outcrops on Eagle Hill in the Mercur mining district (fig. 12), consists mainly of intermittently exposed, irregular, sill-like intrusive bodies that occur mostly in the Great Blue Limestone and Humbug Formation. These intrusives are mapped from the head of Sunshine Canyon, across Eagle Hill, astride the Ophir Anticline at Mercur, Utah, to the mouth of Mercur Canyon, thence northward, generally parallel to the range front, as far as Silverado Canyon (Tooker 1992). A north-trending dike of rhyolite porphyry reappears, on line, in Ophir Canyon at Ophir, Utah, cuts across the Bowman Limestone and Lynch Dolomite (Cambrian), the Fitchville Formation and Pinyon Peak Limestone, undifferentiated (Mississippian and Devonian), and the Gardison Limestone (Mississippian) (Tooker 1987). It then trends northward to Dry Canyon, where several discontinuous sills occur in Deseret Limestone (Mississippian) on the hangingwall of the Dry Canyon thrust. The intrusive is terminated in a stock or large plug on the north facing slopes of Bald Mountain in the upper member of the Great Blue Limestone. Eagle Hill rhyolite is dated at Mercur by Moore (1973c) at $31.6 \pm 0.9 \mathrm{Ma}$; the unit has not been dated at Ophir.

Thin lamprophyre dikes crop out for short distances on the north and south walls of Ophir Canyon (Gilluly, 1932), but they have not been dated.

\section{Associated Mineral Resources}

The geology and metallogeny of Bingham nappe ore districts are reported in detail elsewhere and are only briefly summarized here. The Bingham nappe is host to the main dissemi- 
nated, skarn, vein, and replacement base- and precious-metal ore deposits in the Oquirrh Mountains in the Bingham, Mercur, and Ophir mining districts. These deposits are localized mainly in structurally disturbed porphyritic igneous and (or) carbonate-rich sedimentary rocks near the lead edges and on the upper plates of thrust faults Tooker (1998). In most cases the ore deposits are at least spatially related to intrusive igneous rocks. The following discussions provide more details of the individual deposits.

\section{The Bingham Mining District}

The central zoned porphyry copper-molybdenum-gold ores are disseminated mostly along closely spaced fractures in the Bingham monzonite porphyry stock and in associated dikes and sills (Peters and others, 1966; John, 1978; and Babcock and others, 1995, 1997). Surrounding these deposits are extensive vein, replacement, skarn, and disseminated lead, zinc, copper, silver, and gold deposits hosted by Oquirrh Group carbonate-rich sedimentary rocks that include the Butterfield Peaks, and Bingham Mine Formations of Upper Pennsylvanian age (Hunt, 1957; Tooker and Roberts, 1970; Swensen, 1975a,b; and Tooker, 1990). The ores occur as veins in faults and as replacements of the folded and faulted limestone horizons (Rubright and Hart, 1968, and Stacey and others, 1967, 1968). Close to the intrusives, the carbonate rocks are metasomatized and copper-gold-rich skarns developed (Atkinson and Einaudi, 1978; Einaudi, 1983; and Cameron and Garmoe, 1983).

\section{The Mercur Mining District}

Disseminated gold, silver, and mercury ores occur as bedded and irregular replacements in limestone and as fissure veins in the "Mercur beds." The veins are described by Kornze (1984a,b), Kornze and others (1992), Faddies and Kornze (1985), Guenther (1973), Klatt and Tafuri (1976), Tafuri (1987), Wicks (1987), and Kerr (1997). Near-surface oxidized ores grade into sulfide ores at depth (Jewell, 1984, and Jewell and Parry, 1987, 1988). These mineralized beds are mostly in the faulted upper part of the Upper Mississippian Silveropolis limestone member of the Great Blue Limestone (Shrier oral commun., 1993). They are on the folded upper plate of the Manning thrust (Tooker, 1987 and 1998). Reserves of disseminated gold ore were exhausted in 1997 and mining ceased (Kerr, 1997).

Heretofore, an unresolved controversy about the origin of Mercur (and Barneys Cayon) gold is based on the Wilson and Parry (1995) determination of a Late Jurassic K/Ar age derived from illite-rich clays in limestones associated with the deposit. As in other Oquirrh Mountain mining districts, there seems to be a close spatial and structural association of ore minerals and Tertiary intrusives at Mercur, hence the previous assumption of a genetic connection (Morris and Tooker, 1996). However, if the Wilson and Parry conclusion is valid, their new older age of mineral deposition at Mercur (and Barneys Canyon) implies that the formation of the gold and associated minerals may have occurred in the hinterland before the Sevier thrust event.

The geologic structures in which the ores occur are consistent with those found elsewhere in the range that were produced by Sevier Orogeny thrust faults. Typically, other Oquirrh Mountains ore deposits are genetically related to hydrothermal late stages of igneous intrusion. Kerr (1997) more recently also concludes that the Mercur ores were formed after the intrusion of the associated Tertiary rhyolite bodies. Why are Jurassic-age clays found in the Mercur (and Barneys Canyon) deposits? There are no known Jurassic plutons to provide heat sources for metamorphism or thrust faulting in the northern and southern Oquirrh Mountains. I believe that stratigraphic and structural data and ore mineral zonation across the Uinta trend indicate that Jurassic-altered rocks were moved eastward on Sevier-age thrusts during the Late Cretaceous orogeny that formed all of the folded Oquirrh Mountains nappes. The main ore deposits in the range were formed or remobilized above the Uinta trend in Sevier-age structures during uplift and Tertiary intrusive activity. The ore deposits on the periphery of the Uinta trend at Mercur and Barneys Canyon were formed at temperatures below those existing at Bingham and Ophir. The Jurassic ages of the Mercur and Barneys Canyon deposit clays were not reset.

However formed, the Jurassic ages of sericite associated with disseminated gold reported by Presnel and Parry (1996) and Parry and others (1997) are questioned by experimental studies. In their fission track and U/Th-He studies of the ages of Carlin-type Au deposits in the Great Basin, Arehart and others (2003) conclude that the Jurassic dates are not derived from single-generation sericite, and their relation to gold deposition is suspect. The gold mineralization at Mercur postdates the associated Oligocene-age rhyolite. U/Th dates of apatite from both of the Barneys Canyon and Bingham deposits also give Oligocene ages.

On geologic and experimental bases, one may now conclude that the question of a Cenozoic age for the Mercur and Barneys Canyon deposits has been settled.

\section{The Ophir Mining District}

Ore minerals at Ophir are bedded replacements irregular replacements, pipelike and vein and fissure as lead, silver, copper, and zinc sulfides and oxides (fig.13). The folded host sedimentary rocks are Lower Paleozoic carbonates on the upper plates of several branch thrusts at the apex of the Ophir Anticline, where it is bent northwestward (Tooker, 1998).

Small amounts of tungsten, bismuth, and cadmium occur in the lower parts of the Ophir Hill mine (Rubright, 1978), which was one of the largest and most recent producers. Mining in the district ceased in 1972, but the ore zone was not bottomed according to Rubright (oral commun., 1988). The main part of the district (Ophir Hill \} was recently purchased by Silver Eagle Resources, Ltd. (Vancouver, B.C., Canada).

\section{Production from Bingham Nappe Mining District}

The historic production from the mining districts in the nappe is shown in table 5. Ores produced from the separate areas within the Ophir district are not specified, and the pre- 
1902 data at Ophir are combined with those from the Stockton mining district (from USGS and United States Bureau of Mines data). The Bingham and Barneys Canyon districts are the sole remaining mining operations. Their most recent production is reported by Babcock and others $(1995,1997)$ and Krahulac (1997) (table 5). The mining phase of the Bingham district is expected to end in or about 2030 with the physical and economic exhaustion of the porphyry copper deposit, according to Krahoulac. The lands and construction materials immediately adjacent to the range will then become available for use in the development of expanded urban growth in the Salt Lake and Tooele Valleys.

\section{Industrial Minerals and Construction Materials}

These materials were mined within and bordering the Bingham nappe (Tripp, 1992). Limestone, used for flux in smelting of metallic ores, was produced from the Deseret Limestone in Mercur Canyon. Production data are unavailable. Production from extensive sand and gravel deposits that occur along the margins of the range and on the extensive pediments also is not known. The well-known Stockton bar and spit deposits of sand and gravel immediately west of Stockton were accumulated by the Lake Bonneville currents along the west side of the range, which modified the extensive older unconsolidated Harkers Fanglomerate deposits along the margin of the range.

\section{Rogers Canyon Nappe}

The Rogers Canyon nappe crops out in the northern onethird of the Oquirrh Mountains (fig. 13). It was emplaced by the North Oquirrh thrust fault to a site overlying the Uintatrend buttress. The nappe is composed of a nearly 4,000-mthick stratigraphic section and is divided into five formations (Tooker and Roberts, 1970). The general lithologic characteristics, fossils, age correlations, and map distributions of the formational units are based on the measured sections in type localities at the north end of the Oquirrh Mountains by Gordon and Duncan (1970) and Tooker and Roberts (1970, 1971a,b,c). These data are summarized in table 6.

The north end of the Oquirrh Mountains is bordered by the Great Salt Lake and by east-trending reverse or thrust faults in the Black Rock Fault Zone. The western margin of the range lies along intersecting northwest- and northeasttrending normal faults. A pediment beyond the western range front is terminated by strong, deep-reaching normal faults that define the easternmost margin of the Tooele graben of Cook and others (1966). The southern border of the nappe lies along the North Oquirrh thrust, and is exposed best in Bates Canyon. East of the crest of the range, the thrust is concealed by downdrop of the nappe along the steep-dipping northwestand northeast-trending Nelson Peak and Tooele Faults. The eastern side of the nappe is in contact with Quaternary alluvial deposits, the thick fan deposits of the Harkers Fanglomerate, and Tertiary volcanic units.

\section{Distinguishing Stratigraphic and Structural Features}

The succession of Paleozoic sedimentary rocks in the Rogers Canyon nappe were deposited in the Sublette Basin. Fold and fault structures in the nappe resulted from emplacement of the nappe from the northwest by the North Oquirrh thrust fault (fig. 3) and subsequent adjustments along Basin and Range extensional normal faults (Roberts and Tooker, 1961). The rocks share some correlative lithologic and age characteristics with those in the Bingham nappe in the Oquirrh Mountains, as well as with those composing nappes in some of the adjoining ranges. These similarities initially delayed earlier recognition of them as a separate rock sequence. This report presents defining characteristics that establishes the Rogers Canyon nappe. The summary map (fig. 13) does not show individual Oquirrh Group formations. They are detailed in the Mills Junction, Farnsworth Peak, Magna, and Bingham Canyon quadrangles (Tooker and Roberts, 1971a,b,c, and 1988). The distribution of the underlying conformable Greene Ravine Formation and the overlying disconformable Grandeur Member of the Park City Formation are shown in figure 13.

\section{Defining Nappe Stratigraphy}

The Upper Mississippian Green Ravine Formation at the base is overlain conformably by the Oquirrh Group, composed of the Lower Pennsylvanian (Morrow) Lake Point Limestone, the Middle Pennsylvanian (Desmoines) Erda, and Upper Pennsylvanian (mostly Virgil) Kessler Canyon Formations (table 6). The basal Grandeur Member of the Lower Permian (Leonard) Park City Formation forms the top of the measured section. The stratigraphic section of the nappe is much thinner than that in the Bingham nappe and differs from it in several ways (fig. 4).

The more than 432-m-thick Green Ravine Formation is correlative in age faunally with the Mercur member of the Great Blue Formation in the Bingham nappe and the Doughnut Formation in the Mount Raymond nappe (Crittenden, 1959; Tooker and Roberts, 1962; and Gordon, Tooker and Dutro, 2000). Transition from the Upper Mississippian to Lower Pennsylvanian, which is within the very prominant Manning Canyon Shale in the Bingham and Timpanogos nappes, is in conformable limestone in the base of the overlying fossiliferous 629-m-thick Lake Point Limestone. In addition to the abundant brachiopod, foraminifera, coral and bryozoan fauna, the conodonts in the formation demonstrate the presence of diverse platform elements and permits recognition of the Mississippian-Pennsylvanian (Chester-Morrow) and Morrowan/Atokan boundary (Davis and Webster, 1987; Davis and others, 1994).

The Erda Formation is a 1,255 $\mathrm{m}$ thick sequence of cyclical carbonate beds (table 6) similar in composition with those in the Bingham nappe. The overlying sparsely fossiliferous Kessler Canyon Formation, about 1,362 m thick, consists predominantly of interbedded massive orthoquartzite, calcareous quartzite, 


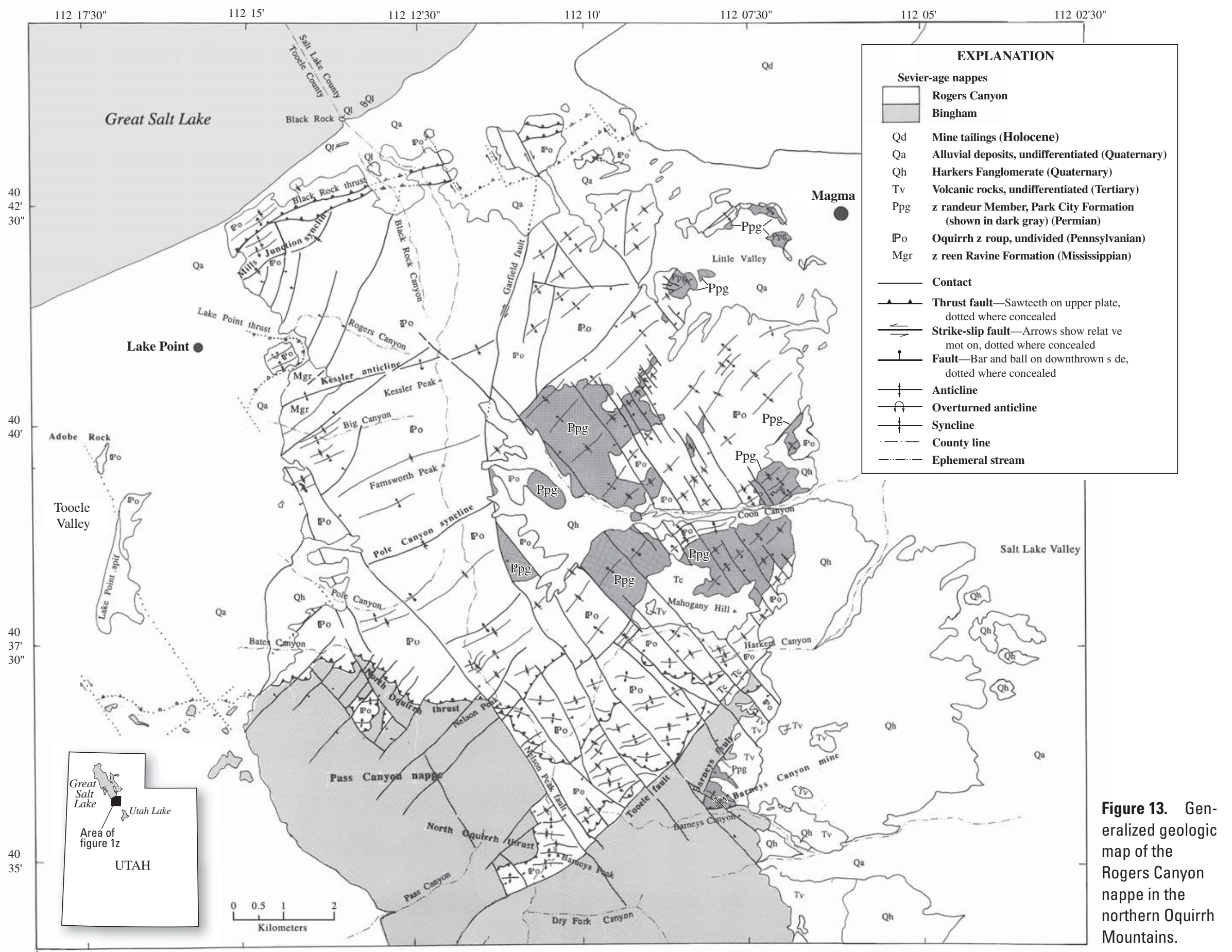


Table 6. Summary of lithology of Paleozoic formations in the Rogers Canyon nappe (Tooker and Roberts, 1970).

\begin{tabular}{|c|c|c|c|c|c|}
\hline Age & Group & Formation & Member & Thickness (m) & Lithology and correlation \\
\hline \multicolumn{6}{|c|}{ Erosional unconformity } \\
\hline Tertiary (?) & N.A. & $\begin{array}{l}\text { Unnamed } \\
\text { conglomerate }\end{array}$ & N.A. & Unknown & $\begin{array}{l}\text { Poorly sorted reddish-brown, limonite-stained } \\
\text { consolidated gravels capped by andesite breccia. May } \\
\text { be correlative with the Apex conglomerate at Tintic } \\
\text { (Morris and Lovering, 1961). }\end{array}$ \\
\hline \multicolumn{6}{|c|}{ Unconformity } \\
\hline $\begin{array}{l}\text { Late } \\
\text { Pennsylvanian } \\
\text { (Missouri- } \\
\text { Virgil) }\end{array}$ & Oquirrh & Kessler Canyon & N.A. & 2,145 & $\begin{array}{l}\text { Upper part is thin- to medium-bedded, interbedded } \\
\text { orthoquartzite calcareous, ferruginous, and dolomitic } \\
\text { sandstone, and dolomite. Lower part is thick, silica- } \\
\text { cemented orthoquartzite and cherty limestone. Local } \\
\text { sedimentary dolomite breccia. Worm trails are com- } \\
\text { mon, poorly preserved fusulinids in bedded chert lay- } \\
\text { ers. Correlative in age with the Clipper Ridge Member, } \\
\text { Bingham Mine Formation. }\end{array}$ \\
\hline $\begin{array}{l}\text { Middle } \\
\text { Pennsylvanian } \\
\text { (Desmoines) }\end{array}$ & & Erda & N.A. & 530 & $\begin{array}{l}\text { Cyclically repeated layers of medium-gray limestone and } \\
\text { dark-gray argillaceous limestone, light-brown carbona- } \\
\text { ceous shale, medium brown and tan calcareous quartz- } \\
\text { ite, crossbedded light-brown sandstone. Argillaceous } \\
\text { and cherty limestones are abundantly fossiliferous with } \\
\text { gastropods, bryozoans, brachiopods, and fusulinids. } \\
\text { These rocks are the approximate age equivalents of } \\
\text { the lower and middle parts of the Oquirrh Group in the } \\
\text { thick Oquirrh and Wasatch Mountain nappes and the } \\
\text { thin Wasatch (Mt. Raymond sequence) (Crittenden, } \\
\text { 1959). }\end{array}$ \\
\hline $\begin{array}{l}\text { Early } \\
\text { Pennsylvanian } \\
\text { (Morrow) }\end{array}$ & & $\begin{array}{l}\text { Lake Point } \\
\text { Limestone }\end{array}$ & N.A. & 432 & $\begin{array}{l}\text { Interbedded medium- to light-gray, tan-weathered, } \\
\text { thin- to medium-bedded limestone and massive (thick } \\
\text { bedded) gray limestone. Locally the limestone is } \\
\text { cherty and contains bioclastic, crossbedded, and } \\
\text { arenaceous layers and shale partings. Beds in upper } \\
\text { part are more massive and less fossiliferious than those } \\
\text { below. Cyclic repetitions of beds is common. Locally } \\
\text { abundant fossils include bryozoans, brachiopods, and } \\
\text { coral assemblages. Formation is an age equivalen of } \\
\text { the Manning Canyon Shale at the base and the West } \\
\text { Canyon Limestone above in the Bingham nappe, and } \\
\text { the Bridal Veil Falls Formation in the Timpanoghos } \\
\text { nappe in the Wasatch Mountains (Baker and Crittenden, } \\
\text { 1961). }\end{array}$ \\
\hline
\end{tabular}


Table 6. Summary of lithology of Paleozoic formations in the Rogers Canyon nappe (Tooker and Roberts, 1970).-Continued

\begin{tabular}{|l|c|c|c|c|c|}
\hline $\begin{array}{c}\text { Age } \\
\begin{array}{l}\text { Late } \\
\text { (Chester) }\end{array}\end{array}$ & Group & Formation & Member & Thickness (m) & Lithology and correlation \\
\hline & Green Ravine & N.A. & 232 & $\begin{array}{l}\text { The upper part is medium-bedded to massive (0.96- to } \\
1 \text {-m-thick, medium-gray, locally fossiliferous limestone, } \\
\text { banded nodular black cherty limestone interbedded with } \\
\text { thin argillaceous and fossiliferous limestone beds. The } \\
\text { lower part is 0.3- to 0.6-m-thick limestone and shale } \\
\text { beds. Limestone is dark gray to olive gray, shale is black. } \\
\text { Formation is fossiliferous with brachiopods, corals, and } \\
\text { bryozoans, and is correlative with the upper part of the } \\
\text { Great Blue Limestone in the Bingham and Timpanogos } \\
\text { nappes in the Oquirrh and Wasatch Mountains and the } \\
\text { lower part of the Doughnut Formation in the Mount } \\
\text { Raymond (thin) sequence in the Wasatch Mountains. }\end{array}$ \\
\hline
\end{tabular}

and cherty limestone, which becomes interbedded ferruginous dolomite, dolomitic sandstone, dolomite, and thin fusulinid chert layers in the upper part. It contains highly altered ironstained zones in its upper parts-perhaps evidence of weathered surfaces. The near absence of Missouri-age rocks in the Kessler Canyon Formation, which is in sharp contrast with their abundance in the Bingham Mine Formation, indicates a period of non-deposition or uplift and erosion in the Sublette basin hinterland of the Rogers Canyon nappe. Steele (1960) calls this gap the regional Middle Pennsylvanian unconformity in westcentral and northwest Utah and eastern Nevada. Wolfcamp-age sediments are also missing in the Rogers Canyon nappe, and the Early Permian (Leonardian) Park City strata rest without angular unconformity on Virgil(?) age beds. Comparable rocks are also missing in the Mount Raymond section (Baker and others, 1949; Crittenden, 1959) (fig. 4).

These stratigraphic relations lend further support that Pennsylvanian-Permian sedimentation along the miogeocline shelf varied from north to south across the Sublette and Oquirrh Basins.

\section{Defining Nappe Structures}

The North Oquirrh (sole) thrust and several overlying imbricate thrusts created the main and secondary folds and the normal and tear faults that characterize the Rogers Canyon nappe. It is bisected into western and eastern parts by the Garfield Fault, which has both tear and normal fault character. The sole thrust is exposed underlying the western side of the range, and the eastern side is underlain by an imbricate thrust, which may be exposed at the head of Harkers Canyon.

Nappe fold patterns differ in the western and eastern halves of the range. The Mills Junction Syncline, Kessler Anticline, Farnsworth (formerly Coon) Syncline, and the Bates Canyon Anticline main folds are well exposed along the western flank of the range as broad, high-amplitude, and southeastleaning asymmetrical structures.

No prominent main folds occur in the eastern half of the nappe. Instead, the folds are closely spaced, symmetrical and open, northeast-trending, and generally low-amplitude structures whose axes plunge gently to the northeast. The rocks include Upper Pennsylvanian and Lower Permian strata noted above (Tooker and Roberts, 1971b). Flat lying Tertiary conglomerate is overlain by a thin 1-m-thick layer of Tertiary volcanic rocks. Quaternary sedimentary rock units include the Harkers Fanglomerate and Quaternary alluvial deposits along the east margin of the range.

The North Oquirrh thrust moved the nappe southeastward from the Sublette Basin. One may speculate that the earliermoved Mount Raymond nappe in the Wasatch Mountains and the overlapping Antelope Island (Precambrian age) nappe (Hansen and McCarley, 2000) formed an obstruction to direct eastward transport, causing the Rogers Canyon nappe to veer southward to rest on the Pass Canyon and Bingham nappes, which overlay the Uinta trend.

The North Oquirrh thrust crops out in Bates Canyon, on the western side of the range, and also in a structural block that includes Barneys Peak. The thrust is a shallow north-dipping fault at the mouth of Bates Canyon, and apparently also along the western front of the range where it is inferred to underlie the Adobe Rock pediment between Lake Point and the mouth of Bates Canyon. However, the northern dip of the thrust steepens upward as the nappe ramps southeastward up Bates Canyon toward Nelson Peak. The North Oquirrh thrust is not recognized east of the Nelson Peak Fault.

The nappe contains a number of imbricate thrust faults. One of them, a small folded imbrication in the upper plate of the North Oquirrh thrust at the mouth of Rogers Canyon, the Lake Point thrust, is underlain by tight, isoclinal, low-amplitude, northeast-trending folds of the Middle Pennsylvanian Erda Formation, which are overturned to the southeast. Stratigraphic units of the Erda Formation, which normally underlie the Lake Point thrust, are overlain by the older Green Ravine Formation and Lake Point Limestone.

The upper plate of the Black Rock Fault along the northern border of the nappe contains tightly folded, secondary, close-spaced, low-amplitude, asymmetrical, and locally 
overturned folds in Lower and Middle Pennsylvanian strata (Tooker and Roberts, 1971b). The Lake Point Limestone was thrust over Erda Formation, and in turn, is overlapped by flat lying Quaternary (Lake Bonneville and alluvium) deposits along the northern and western sides of the range.

Several other imbricate thrusts that crop out east of the Nelson Peak Fault and have relatively small displacements in the Erda Formation. These imbrications seem to break out and form where the thrust crosses over the Uinta trend. The Nelson Peak and Tooele Faults drop the nappe and conceal the North Oquirrh thrust and also form the boundary between the adjoining Pass Canyon and Rogers Canyon nappes.

The eastern side of the nappe lies above an unexposed imbricate thrust. Steep-dipping tensional-tear faults and later normal Basin and Range extensional faults are also exposed. The steep, north-dipping Black Rock and Pony Express thrusts develop over-steepened to overturned folds in the upper plate and also overlap the nappe east of the Garfield Fault at the north end of the Oquirrh Mountains. Normal faults are predominantly northwest-trending, steep-dipping structures with less prominent conjugate northeast-trending steep faults. None of these faults markedly offset the sedimentary rocks and are mainly tensional and later tear breaks developed during the folding of the nappe.

The western range front consists of intersecting northeast- and northwest-trending normal faults. The Adobe Rock pediment at Lake Point is part of fault blocks that emerge locally above the unconsolidated sediments of Tooele Valley. The blocks to the west in the valley are dropped variable distances below the surface, estimated to be as much as 1.5 $\mathrm{km}$, forming the Tooele graben (Cook, and others, 1966; and Tooker and Roberts, 1971a). The nappe fault boundaries on the eastern side of the range are not as well revealed owing to the eastward tilt of the range and consequent overlap of Quaternary sediments. Some may have been reactivated as Basin and Range normal faults. The eastern part of the range was dropped down along the Garfield Fault.

\section{Proposed Formation of Rogers Canyon Nappe Structures}

Dissimilar stratigraphic and structural features are exposed in the eastern and western parts of the Rogers Canyon nappe. First, there is a striking difference in the stratigraphic character between the Lower and Middle Pennsylvanian rocks exposures on the western side of the range and the Upper Pennsylvanian-Lower Permian rocks on the eastern side. The sedimentary rock succession on the western side of the range includes a high proportion of competent interbedded thick orthoquartzite, calcareous quartzite, and limestone beds of the Lake Point Limestone, the Erda Formation, and the lower part of the Kessler Canyon Formation. Main-type folds with subsidiary small overprinted secondary folds were produced.

The stratigraphic sequence of the upper part of the Kessler Canyon Formation and Grandeur Member strata on the east side of the Garfield Fault include a high proportion of thin- to medium-bedded ferruginous sandstone, dolomite, and shaly limestone units. These rocks are less competent than those on the western half of the range and evenly distributed close-spaced, low-amplitude folds formed on the upper plate of an unexposed imbricate thrust in the Rogers Canyon nappe.

The folds in the western and eastern parts of the nappe occurred in separate detached structural blocks. Movement of the North Oquirrh thrust onto the Uinta trend formed the main folds in thick-bedded strata on the western side of the range. The Garfield Fault initially was a tear fault boundary of the imbricate thrust on the eastern range block.

East-side folds developed in an upper imbricate plate separated from the west-side plate. The southern leading edge of the imbricate thrust is inferred to be on the ridge south of Harkers Canyon, where the thrust plane is marked by a thick silicated quartzite breccia formed against the Uinta trend. Normal faulting along the Garfield Fault during Basin and Range extension dropped the eastern side down to its present position. Erosion completed the present topography.

The Black Rock imbricate thrust zone moved the Lower Pennsylvanian Lake Point and Erda Formations along the northern range front to overlap both the west- and east-sides of the nappe.

\section{Location and Types of Igneous Rocks}

The only igneous rocks present in the nappe occur close to the southern fault border with the Pass Canyon nappe. They are related to intrusions originating in the underlying Pass Canyon nappe. A thin (as much as $1.2 \mathrm{~m}$ thick) flow composed of andesite breccia, apparently conformably overlies Tertiary conglomerate capping the low ridge west of Mahogany Hill in the southeastern corner of the Farnsworth Peak (Garfield) quadrangle (Tooker and Roberts, 1971b). This rock has not been dated. Tertiary flows of latite and latite breccia crop out along the southeastern range front (Swensen, 1975a and 1975b), where they unconformably overlap the sedimentary rocks of the nappe.

\section{Associated Mineral Resources}

The Rogers Canyon nappe is not mineralized, however, the Barneys Canyon disseminated gold mine (Skillings, 1988) is located mainly in the Pass Canyon nappe near its contact with the Rogers Canyon nappe (Babcock and others, 1995). Hydrothermal solutions penetrated and altered a sliver of Grandeur Member limestone in the North Oquirrh thrust fault that overlies the Flood Canyon unit near the mouth of Barneys Canyon. The adjoining unmineralized Grandeur Member crops out elsewhere in the Farnsworth Peak and Magna quadrangles (Tooker and Roberts, 1971b, 1971c). It has been prospected with little apparent success.

Industrial mineral and construction materials were produced from or peripheral to the Rogers Canyon nappe (Tripp and others, 1989; and Tripp, 1992). While some of these materials are not directly derived from the nappe, they 
are indirectly the result of its erosion and concentration by evaporation in Great Salt Lake. Gravel deposits formed about the margins of the Oquirrh Mountains by Pleistocene Lake Bonneville were mined extensively in the area for road metal and for construction of mine facilities and evaporators. A byproduct of smelting activity at the north end of the range is crushed smelter slag used in construction of highways, as railroad ballast, and the Great Salt Lake containment dikes. Oolitic carbonate sands that occur along the southern shores of Great Salt Lake were mined for use as a flux in the adjoining Kennecott refinery. Halite has been recovered from the evaporation of Great Salt Lake brines. Data on the production of most of these materials are unavailable.

\section{South Mountain Nappe}

The South Mountain nappe is located partly on South Mountain and an adjoining area east of Stockton, Utah, on the western side of the central part of the Oquirrh Mountains. It includes the Stockton mining district (Tooker and Roberts, 1992) (fig. 14). The nappe is the upper plate of the sole Stockton thrust fault, recognized initially because of its overall stratigraphic and structural discordance with geologic features in the adjoining Bingham nappe. North of South Mountain, the northern boundary of the nappe is along the inferred TAD ${ }^{5}$ thrust fault, which is concealed beneath Quaternary alluvium. The South Mountain nappe is overlapped on the west by the Tintic Valley thrust fault whose upper plate is the Stansbury Mountains nappe (Tooker, 1983). The eastern boundary of the nappe is the Soldier tear fault at the mouth of Soldier Creek. Quaternary alluvial deposits overlap the nappe on the south.

\section{Distinguishing Nappe Stratigraphic and Structural Features}

The sedimentary rocks in the nappe include three informally named formational units of the Oquirrh Group: the South Peak, Salvation, and Rush Lake units of Tooker and Roberts (1988) (table 7). Although there is a general gross similarity in the types of rocks comprising the Oquirrh Group in the South Mountain and Bingham nappes, the lithologic character of South Mountain sedimentary rocks is sufficiently different now to recognize them as a separate structural unit.

The patterns of folded and faulted sedimentary rocks in the South Mountain nappe contrast markedly with those in the Bingham nappe. Gilluly (1932) correlated the major fold on South Mountain with a westward extension of the Ophir Anticline. More detailed mapping by Tooker and Roberts (1992) indicates their stratigraphic and structural discordance. The sole Stockton thrust of the nappe in the Oquirrh Mountains and the imbricate TAD thrust north of South Mountain are most probably different faults separated by an inferred Rush

\footnotetext{
${ }^{5}$ TAD is the acronym for Tooele Army Depot, which includes most of the area in Tooele Valley north of South Mountain.
}

Valley (tear) fault of moderate but unknown offset, and later normal fault displacement, west side down (fig. 14).

\section{Defining Nappe Stratigraphy}

Although there is structural discontinuity across the Rush Valley Fault, the sedimentary rocks on both sides are readily correlated in age, and to an extent they also share characteristic formational composition of the Oquirrh Group in the Bingham nappe (fig. 15). The South Mountain rocks are overlapped by unconsolidated sediments of Quaternary age. The type localities and measured sections of the formational units in the nappe are on South Mountain (Tooker and Roberts, 1992), and details of their lithology are shown in appendix 2. The Rush Lake and Salvation units also crop out in the Stockton mining district. The units are not areally extensive, and possibly do not warrant more than the unit designation accorded here. They were included previously with rocks of the Bingham nappe (Welsh and James, 1961), but such designation does not recognize their separate distinctive stratigraphic and structural characteristics.

The type locality of the Rush Lake unit on South Mountain consists of nearly $1,352 \mathrm{~m}$ of interbedded carbonate beds of Middle Pennsylvanian (Desmoines) age. The base of the unit is concealed by Quaternary sand and gravel deposits on the shore of Rush Lake. Only the upper part of the unit is exposed in the Stockton mining district (appendix 2C, and Tooker and Roberts, 1992). A sparse coral, bryozoan, and fusulinid fauna is age-correlative with the upper part of the Butterfield Peaks Formation (R.C. Douglass, written commun., 1962; Mackenzie Gordon, Jr., written commun., 1966). However, the thick sequence of cyclic repetitions of limestone, quartzite, sandstone, and shale, which are characteristic of the neighboring Butterfield Peaks Formation, are absent in the South Mountain nappe. The clean, rounded sand grains in well-sorted clastic rock materials are characteristic of nappe sedimentary rocks, and inferred derived from a distant craton source.

Salvation unit of Tooker and Roberts (1988) is named for exposures generally north of Ben Harrison Gulch near the Salvation mine in the Stockton mining district. The 823-mthick type locality is on adjoining South Mountain (Tooker and Roberts, 1988). Medium-bedded quartzite predominates over thin-bedded limestone and shale partings (appendix $2 B$; Tooker and Roberts, 1992). The rocks are age-correlative with the Late Pennsylvanian (Desmoines) Clipper Ridge Member of the Bingham Mine Formation (Mackenzie Gordon, Jr., and R.C. Douglass, written commun. 1962). A distinctive stratigraphic difference between the Bingham and South Mountain nappes is the presence of thick limestone marker beds (the Jordan and Commercial marker beds) at the base of the Clipper Ridge Member in the Bingham nappe. They cross the range near Tooele undiminished in thickness and are not present in the Salvation unit in the South Mountain nappe (Tooker and Roberts, 1970) (fig. 15). These beds are the main base-metal ore horizons at Bingham, and comparable-age beds in the Stockton district also host base-metal ores. 


\section{EXPLANATION}

\section{Sevier-age nappes \\ South Mountain \\ Bingham}

Qa Alluvial deposits, undifferentiated (Quaternary)

Qh Harkers Fanglomerate (Quaternary)

$\mathrm{T}$ Porphyritic intrusive rocks (Tertiary)

PPoso Oquirrh z roup, South Park unit of Tooker and Roberts (1992) (Permian-Pennsylvanian,)

Pos Oquirrh z roup, Salvation unit of Tooker and Roberts (1992) (Pennsylvanian)

Por Oquirrh z roup, Rush Lake unit of Tooker and Roberts (1992) (Pennsylvanian)

$$
\text { Contact }
$$

$\_$Thrust fault - Sawteeth on upper plate, dotted where concealed

$\leftrightharpoons$ Strike-slip fault-Arrows show relat ve mot on, dotted where concealed

. Fault-Bar and ball on downthrown s de,

$$
\text { dotted where concealed }
$$

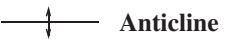

ति Overturned anticline

$\downarrow$ Syncline

ती Overturned syncline Ephemeral stream

Figure 14. Generalized geologic map of Paleozoic and Permian carbonate formations in the South

Mountain nappe on South Mountain and in the west-central Oquirrh Mountains. The trace of the Uinta zone axis is also shown. 
Table 7. Summary of lithology of Paleozoic formations in the South Mountain nappe (Tooker and Roberts, 1992).

\begin{tabular}{|c|c|c|c|c|}
\hline Age & Group & Formation & Thickness & Lithology and correlation \\
\hline \multicolumn{5}{|c|}{ Erosion surface } \\
\hline $\begin{array}{r}\text { Early Permian } \\
\text { (Wolfcamp) }\end{array}$ & N.A. & $\begin{array}{l}\text { South Peak unit of Tooker } \\
\text { and Roberts (1992) }\end{array}$ & 1,966 & $\begin{array}{l}\text { Predominantly calcareous quartzite, me- } \\
\text { dium-bedded to massive, light buff-tan } \\
\text { to olive-gray, weathers reddish-brown, } \\
\text { thin surface rind, well jointed, worm } \\
\text { trails common. Thin interbedded } \\
\text { silica-cemented quartzite, fossiliferous } \\
\text { medium-gray, sandy and platy lime- } \\
\text { stones with fusulinids (mostly frag- } \\
\text { mental), calcareous mudstone, local } \\
\text { bedded chert, phosphatic chert, and } \\
\text { ferruginous sandstone that weathers } \\
\text { yellow-brown; mostly covered slope. } \\
\text { Age correlative with the Dry Fork unit } \\
\text { in the Pass Canyon nappe (Tooker and } \\
\text { Roberts, 1988). }\end{array}$ \\
\hline \multicolumn{5}{|c|}{ Covered } \\
\hline
\end{tabular}


South Mountain

nappe

5
5
5
5
$\vdots$
0

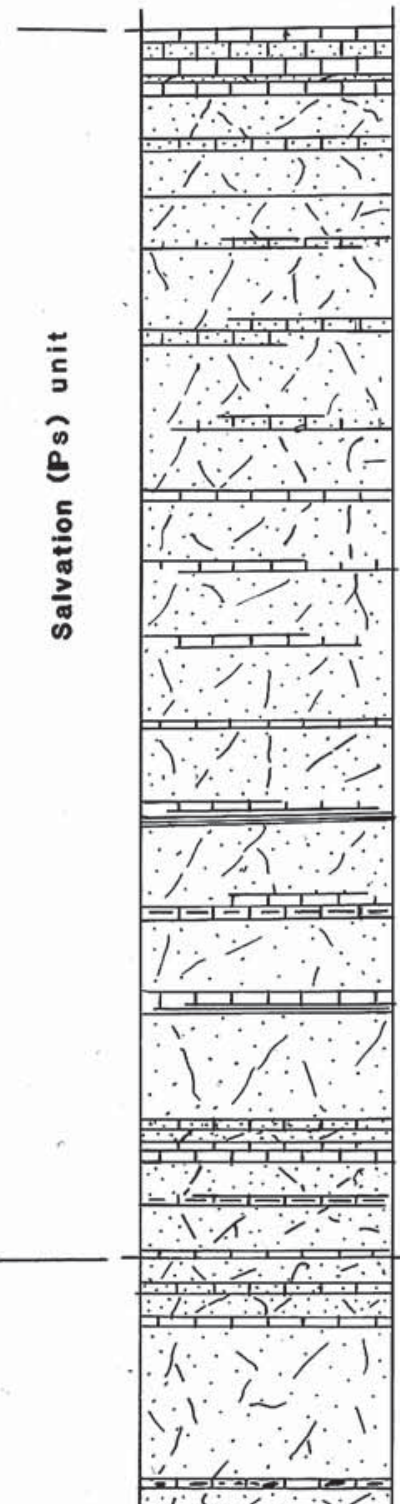

Bingham nappe

(Tooker and Roberts,1970)
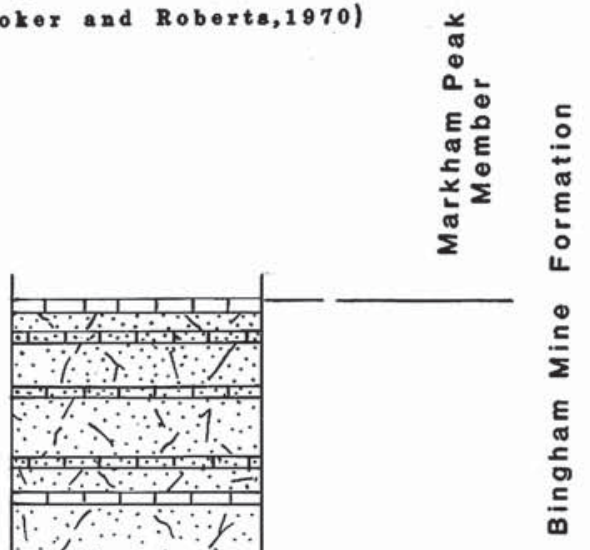

EXPLANATION

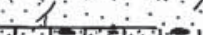

$\%$ \%

$1 \%$

$1-1-1-1$

I I

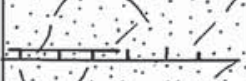

$1 \because \because \cdots$

\%

$\therefore$

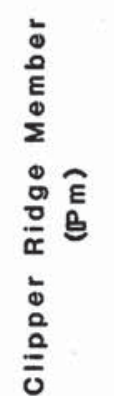

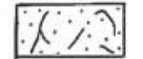

Quartzite

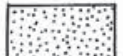

Sandstone

$\frac{\sqrt{2}}{\frac{1}{0}}$

$\frac{1}{\lambda}$

ᄃ

$\% \because \%$

$\because \backslash \because \because \%$

$\frac{\pi}{\cdots}$

\%

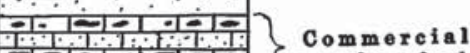

Commercial
marker bed

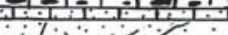

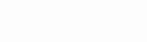

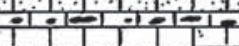

D

Jordan
marker bed

$1,1.12 .10$

$\frac{1}{1 \% \quad 1 \quad 1}$

,

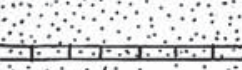

$x \% \%$

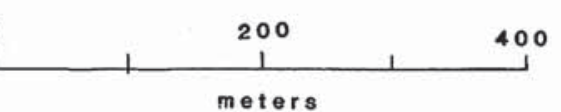

兵置 Limestone

Sandy limestone

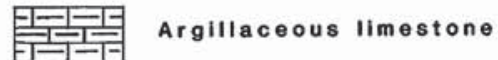

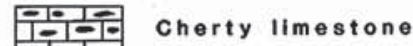

vertical scale

meters 


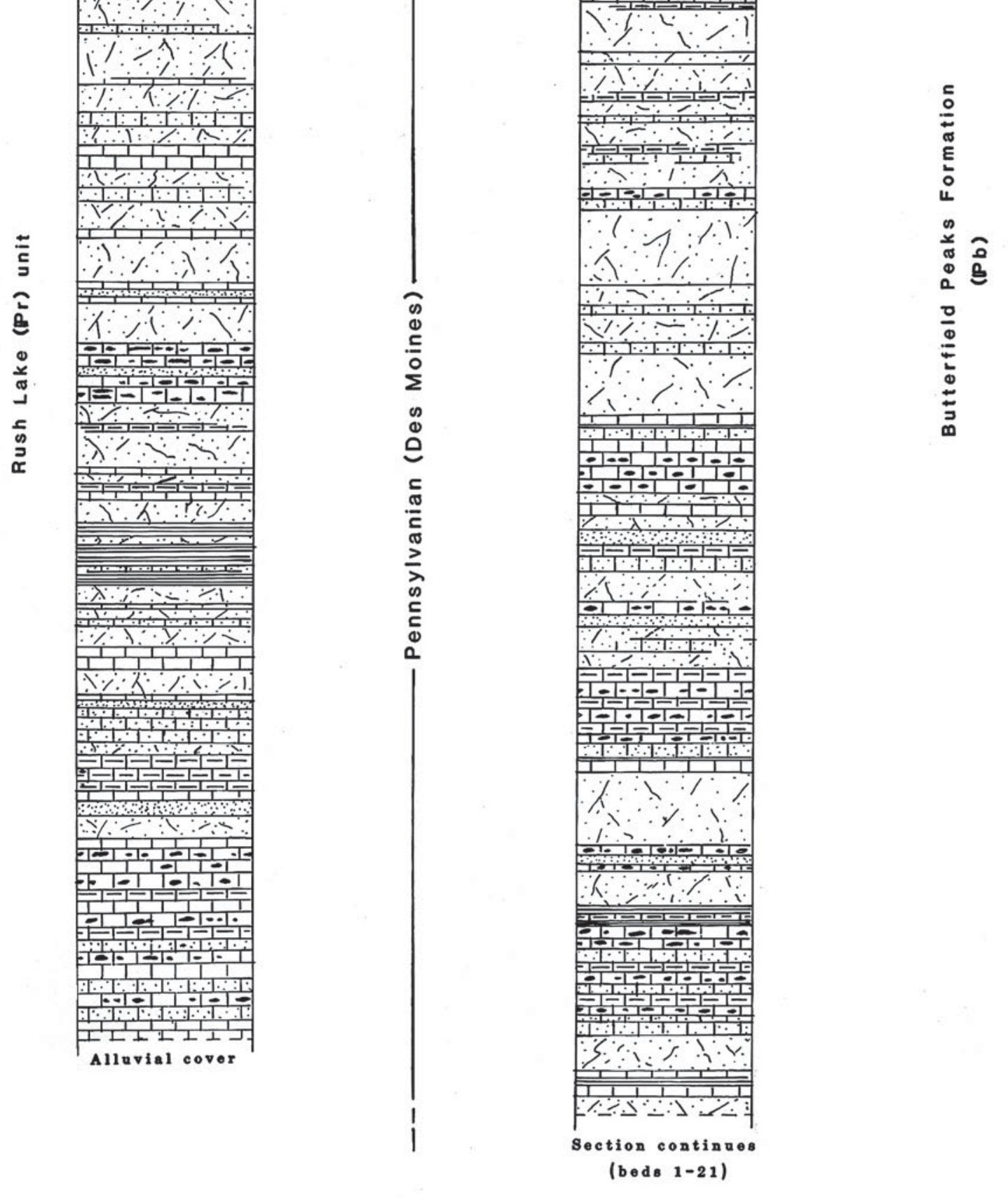

Figure 15. Comparative columnar stratigraphic sections of common parts of the Pennsylvanian (Des Moines and Missouri) of the South Mountain and Bingham nappes. 
The South Peak unit of Tooker and Roberts (1988) is $1,903 \mathrm{~m}$ thick where exposed along the crest of the western part of South Mountain and is named for the peak labelled "South" in the high southwestern part of the range. Orthoquartzite beds and ferruginous sandstone predominate. Few well-preserved fossils occur. Ferruginous sandstone contain worm trails, thin-bedded chert with fusulinid molds, and, less commonly, thin-bedded dark-gray sandy limestone. The age suggested is Early Permian, late Wolfcamp equivalent. (R.C. Douglass, written commun. 1963). The lowest South Peak strata are probably correlative with the upper Markham Peak Member of the Bingham Mine Formation (Missouri-Virgil age) in the Bingham nappes. Sedimentary rocks of Wolfcamp age found in the upper part of the South Peak unit do not occur in the Oquirrh Mountains.

The lithology of rocks in the South Mountain nappe and those of Missouri-, Virgil-, and Wolfcamp-age in the southernmost part of the Bingham nappe at Tintic also differ. The Furner Valley Limestone at Tintic is correlated with parts of the Upper Pennsylvanian and Lower Permian South Peak and Salvation units in the South Mountain nappe. Furner Valley Limestone is overlain by Diamond Creek Sandstone. These formations may be partly correlative in age with the upper part of the South Peak unit of Tooker and Roberts (1988).

Quaternary deposits include the Harkers Fanglomerate and Quaternary alluvium. The alluvium also includes Pleistocene clastic sand and gravel deposits formed along the shores of Lake Bonneville. The thick Harkers Fanglomerate deposits occur on both sides of the Oquirrh Mountains and are thickest where they overlie the trace of the Uinta trend, which continued to be uplifted during the Quaternary. These deposits were partly redistributed along the shore by Pleistocene Lake Bonneville currents. The classic bar and spit deposit at Stockton, described by Gilbert (1886), and numerous smaller sand and gravel deposits in Tooele Valley formed in successively lower lake levels in the adjoining Tooele Quadrangle are described by Tooker (1980).

Ages of Bingham nappe sedimentary rocks on the south flank of the Ophir Anticline at the range front near the mouth of Soldier Canyon, and those in the adjoining well-folded South Mountain nappe overlying the Stockton nappe are dissimilar. The rocks in the two nappes are also structurally discordant. The Bingham nappe strata at the range front includes Mississippian Great Blue Limestone, MississippianPennsylvanian Manning Canyon Shale, and Lower and Middle Pennsylvanian West Canyon Limestone. The adjacent rocks in the South Mountain nappe include only the upper part of the Middle Pennsylvanian Rush Lake and the lower part of the Upper-Pennsylvanian Salvation units.

\section{Defining Nappe Structures}

Two areas of contrasting fold and fault structures are on the upper plates of the Stockton and TAD thrusts on the South Mountain nappe and are separated from one another by the Rush Valley tear fault (fig. 14). The eastern border of the nappe with the Bingham nappe lies along the Soldier tear fault, and although concealed by unconsolidated Quaternary deposits, the western part of the South Mountain nappe is overlapped from the west by the east-directed, north-south trending, later Tintic Valley sole thrust.

The thinned south-southwest dipping, cyclic limestone, shale, and quartzite thin interbeds on the north- northeast leading edge of the nappe ramp over the Uinta trend and previously docked Bingham nappe. Close-spaced, small-amplitude, locally asymmetrical to overturned secondary folds above the Stockton thrust in the Stockton mining district area are aligned in an east-northeast- to west-northwest-trending arc. The folds are segmented by tensional steep-dipping, north-northeast trending normal faults.

In contrast, the major fold structure exposed in the western part of the nappe on South Mountain defines a single high-amplitude main fold, the South Mountain Anticline (fig. 14), that also moved generally north-northeast on the TAD thrust. The western part of the nappe is composed of a competent, thick stratigraphic body of medium-to-thick-bedded sedimentary rocks of the Rush Lake, Salvation, and South Peak units (Tooker and Roberts, 1992). The fold is asymmetrical, locally overturned to the north, and lies in a northwest- to west-northwest-trending more-open arc. The arcuate trend of the anticline on South Mountain is due, in part, to drag along the Rush Valley tear fault, and the overturn at the west end is ascribed to drag along the TAD thrust fault against the Uinta trend. The fold plunges westward beneath the Tintic Valley thrust. Before the Sevier thrust belt was recognized, Gilluly (1932) considered that this fold was a continuation of the Ophir Anticline, which it seemed to extend. However, the Ophir Anticline plunges beneath overlying imbricate thrusts in the Bingham nappe along its western border (Tooker and Roberts, 1992), and is terminated by the Soldier (tear) Fault. The folds west of the fault are distinctly different types and are directionally discordant.

Although there seems to be only a moderate amount of stratigraphic displacement along the Rush Valley tear fault, folds on the upper plate of the Stockton thrust are characteristic of those developed in a thinned-plate wedge that laps onto the uplifted Bingham nappe, which overlies the Uinta trend. The South Mountain main anticline on South Mountain may best be explained as having formed farther southwest as a thicker, and therefore more competent upper plate that moved on the TAD imbricate thrust. It overran the thinner lead wedge of the Stockton thrust, as it also crunched against the Uinta trend barrier.

The principal faults in the nappe are sole and imbricate thrusts, tear, and normal faults. They differ from those observed in the adjoining Bingham nappe. The Stockton thrust is the sole fault of the South Mountain nappe. It is exposed north of the Stockton mining district overlapping the Bingham nappe, and is moderate-to shallow, south dipping. The amount of northeastward transport on the Stockton thrust is not known, but does not seem to be of the same magnitude as that on the Midas thrust. The Stockton thrust brings a facies that 
was deposited in the Oquirrh Basin south of the Uinta trend, and resembles strata of the Bingham nappe in the Tintic area. Several branch or imbricate thrust faults having much less throw occur in the upper plate in the Stockton mining district. In the western part of the South Mountain nappe the TAD thrust block was dropped down along what had been the Rush Lake tear fault during the later Basin and Range extensional structural deformation.

Movement on the nearly vertical Rush Valley tear fault is not known. It does not crop out and must be inferred from several lines of evidence. Most obvious is the striking difference in the folded rock structure on both sides of the fault (fig. 14). The presence of several warm springs along its trend from Morgan Ranch to the shores of Rush Lake is also permissive evidence of an unexposed fault. The source of heat sustaining these hot springs is believed to be related to young basaltic or bimodal volcanic systems, similar to those elsewhere in central Utah (H.T. Morris, oral commun., 1997). These occur at depth along the Uinta trend and were related to earlier intrusives and hydrothermal ores in the Stockton mining district.

The structural and stratigraphic discontinuity between South Mountain and the Stansbury Mountains is caused by the concealed Tintic Valley thrust (Tooker, 1983; and Morris, 1983). Contrasting Paleozoic stratigraphic sequences (Rigby, 1958; and Taylor 1991) are juxtaposed by the Tintic Valley Fault, which has comparable regional significance in the Tintic, Utah, region.

The eastern side of the South Mountain nappe adjoins the Bingham nappe along the Soldier tear fault. Outcrops of the Soldier Fault on the eastern boundary of the nappe place contrasting stratigraphic and structural terranes. The southwestward extension of the fault is concealed beneath thick deposits of the Harkers Fanglomerate and younger Quaternary alluvium.

Normal faults, which were largely developed originally as tensional structures formed during the folding of the nappe, may show small normal displacements during Basin and Range extension. These are steeply dipping, north trending faults, and commonly host porphyritic dike rocks in the Stockton mining district. These faults also were conduits for the movement of hydrothermal sulfide solutions that formed veins and altered and replaced adjoining favorable carbonate sedimentary host rocks (Tooker, 1998). Offset of bed on these normal faults is generally small. The Oquirrh Mountains range front is defined by numerous normal extensional faults, which locally also displace the Quaternary gravels. Older Harker Fanglomerate deposits at the mouths of the main drainages are also truncated by these faults.

\section{Location and Types of Igneous Rocks}

The main types of igneous rocks in the South Mountain nappe, originally described by Gilluly (1932) and later by Moore and McKee (1983), are intrusive facies of monzonitic porphyry that occur as small plugs, irregular dike-like bodies, and sills in the Stockton mining district and basalt dikes on
South Mountain. Their ages are in the range of 38 to 39 m.y. (Moore and McKee, 1983). Extrusive volcanic rocks occur locally along the trace of the TAD thrust.

Numerous dikes, sills, and small stocks of quartz monzonite porphyry, and related monzonite porphyry, diorite porphyry, and quartz-diorite porphyry phases occur in and adjacent to the Stockton mining district (Gilluly, 1932). The dikes fill north-trending, near-vertical tension fractures. The composition of the largest stock, locally known as the "Raddatz" porphyry, resembles that of a nearby thick sill near Tooele in the Bingham nappe (Gilluly, 1932; and Tooker, 1980). A smaller fine-grained monzonite porphyry stock near the Calumet mine is dated at $38.0 \pm 1.1$ Ma by Moore (1973a). A number of porphyry sills occur in the southeastern part of the nappe and in adjoining parts of the Bingham nappe on the north side of Soldier Creek. The nepheline basalt sill described by Gilluly (1932), one of four smaller sills exposed nearby on the crest of South Mountain, is dated at 40.1 Ma (Moore and McKee, 1983).

Hornblende latite tuff-breccia, which also includes waterlaid tuffs and flows, is shown on Gilluly's map (1932) on the northeast foot of South Mountain. It is dated at $30.7 \pm 0.9 \mathrm{Ma}$ by Moore (1973a).

\section{Associated Mineral Resources}

Sulfide ore deposits in the Stockton mining district are located on the structurally broken lead edge of the folded upper plate of the Stockton thrust (Lufkin, 1965; Moore and others (1966); and Tooker, 1998). Early production in the Stockton mining district between 1864 and 1901 was combined with that at Ophir; more recent production at Stockton is shown in table 4 . The district has been inactive since 1972. The typical sulfide ores occur in fissure- and beddedreplacement deposits of lead, zinc, copper, gold, and silver. Near-surface ores are oxidized, and grade into sulfide minerals below (Gilluly, 1932). The Stockton district ores occur mainly in the Pennsylvanian Rush Lake and Salvation units of Tooker and Roberts (1992), which are correlated in age with the ore-bearing horizon of the Clipper Ridge Member of the Bingham Mine Formation at Bingham. The ores are in close spatial association with quartz monzonite dikes and plugs and occur mainly along steep-dipping, north-northwest-trending faults and in adjacent locally replaced carbonate beds. The ores seem to diminish at moderate depth, leading to the supposition that mineralization is restricted to the much-broken upper plate of the Stockton thrust. Although prospected thoroughly, the same rocks along the less-broken South Mountain Anticline are not mineralized sufficiently to produce ores.

Mining activity in the Stockton mining district apparently was restricted to the upper plate of the Stockton thrust. No deep exploration seems to have been undertaken to determine if mineralization occurs in the lower plate (Bingham nappe) Butterfield Peaks Formation, which hosts ores in the Bingham mining district. 
Abundant resources of sand and gravel construction materials occur along the edges of the nappe. These locally thick deposits are mainly the result of wave action in Quaternary Lake Bonneville that distributed debris shed from the accelerated erosion of the uplifted nappes overlying the Uinta trend south of the Stockton thrust (Gilbert, 1886). The very substantial Bonneville bar and spit near Stockton, Utah, has been extensively quarried for highway, railroad, and other construction in the area, but no production data are available. Numerous borrow pits also occur in the nearby beach deposits.

\section{Fivemile Pass Nappe}

The Fivemile Pass nappe is located in the southernmost part of the Oquirrh Mountains, immediately north of Fivemile Pass, and mainly in the drainages of Wells and Clay Canyons (fig. 16). The allochthonous Fivemile Pass nappe (originally called Wells-Clay Canyon nappe by Tooker (1987)) is distinguished from the adjoining Bingham nappe by its limited yet distinctive transitional facies composition (table 8), and by its complex discordant fold structures (Tooker, 1987; Tooker and Roberts, 1998). The nappe is bounded on the north and northeast by the Clay thrust, on the west by the Sunshine tear fault, and on the east and south by the inferred Cedar tear fault, which is concealed by Quaternary alluvium (fig. 16). However, the Oquirrh Mountains and its nappes are terminated by the inferred northeast trending Fivemile Pass fault in Cedar Valley. It separates the Oquirrh Mountains from the Thorpe Hills' stratigraphic and structural regimes.

\section{Distinguishing Nappe Stratigraphic and Structural Features}

Sedimentary rocks in the Fivemile Pass include faultbounded, fragmented middle parts of the Upper Mississippian (Chester) Mercur limestone member of Gordon, Tooker, and
Dutro (2000) of the Great Blue Limestone and normally overlying Mississippian-Pennsylvanian (Chester) Manning Canyon Shale (Gordon, written commun., 1985). Unconsolidated Quaternary alluvial deposits overlap the sedimentary rocks.

\section{Defining Nappe Stratigraphy}

The Mercur limestone member is similar in age to the type and reference localities in the southern Oquirrh Mountains (Gordon, Tooker, and Dutro, 2000). In the Fivemile Pass nappe, the member contains relatively larger proportions of shale to limestone. Thick green-black shales and interbedded thin layers of chert and quartzite represent a transition between the Oquirrh Mountains and East Tintic Mountains and was deposited an unknown distance south-southwest of its present location. The section probably is part of the lower-middle part above the Caninia zone of Gordon, (written commun., 1985). Sufficient fossils to age-date these rocks precisely permit only a tentative correlation with the Poker Knoll or Chulios Members of the Great Blue Formation at Tintic (Morris and Lovering, 1961).

The member differs from the Oquirrh Mountains Bingham nappe. Several thick altered shale units in the Wells Canyon locally, originally attributed to the Manning Canyon Shale, were mined for brick clay (Ornelas, 1953; Hyatt, 1956). The member also contains deposits of variscite (Sinkankas, 1976).

Manning Canyon Shale is correlated with the middle part of the Manning Canyon Shale. About $46 \mathrm{~m}$ are exposed and includes the characteristic thick-bedded, brownish-weathering medial quartzite. Fossil plant debris (Prince, 1963) and mega fossils of Mississippian age (M. Gordon, Jr., written commun., 1990) suggest a transitional facies southward. The unit is overlain by Lake Bonneville unconsolidated sediments.

\section{Defining Nappe Structures}

The folded and faulted sedimentary rocks of the Fivemile Pass nappe are on the upper plate of the sole Clay thrust. They are discordant with and overlap rocks of the

Table 8. Summary of lithology of lower Paleozoic formations in the Fivemile Pass nappe.

\begin{tabular}{|c|c|c|c|}
\hline Age & Formation & Thickness & Lithology \\
\hline \multicolumn{4}{|r|}{ Wells thrust fault } \\
\hline $\begin{array}{l}\text { Late Mississippian } \\
\text { (Chester) }\end{array}$ & $\begin{array}{l}\text { Manning Canyon } \\
\text { Shale }\end{array}$ & 46 m partial & $\begin{array}{l}\text { Mostly shale with thin interbeds of dark gray limestone and thin- to thick- } \\
\text { bedded dark brown weathering quartzite. Limestone is fossiliferous-plant } \\
\text { debris, brachiopods and gastropods. }\end{array}$ \\
\hline \multicolumn{4}{|r|}{ Clay thrust fault } \\
\hline
\end{tabular}




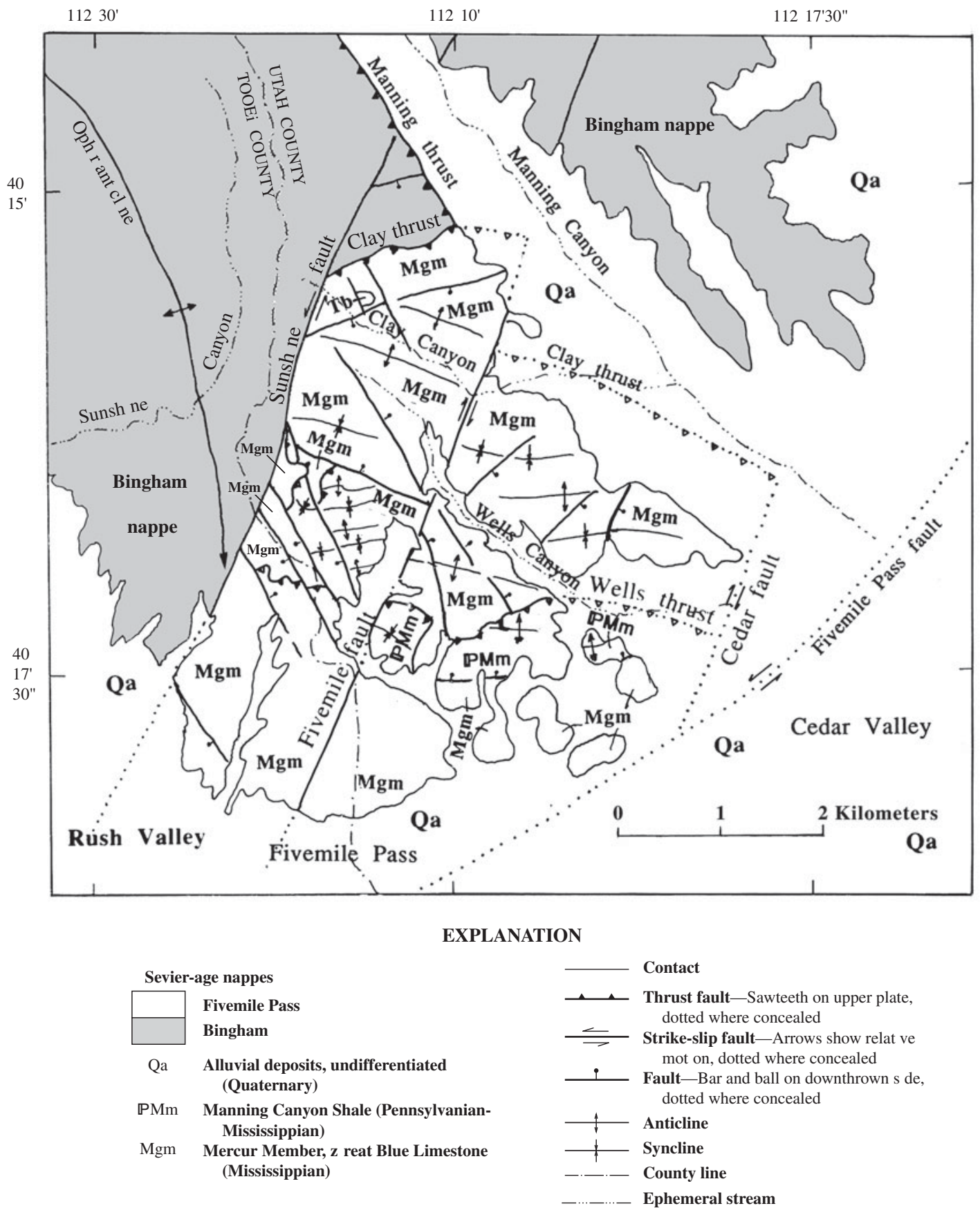

Figure 16. Generalized geologic map of the Fivemile Pass nappe. The adjoining Bingham nappe is shaded. 
Bingham nappe. The nappe was emplaced from the southsouthwest. The main fold in the Bingham nappe, the Ophir Anticline, trends due south and plunges to the south beneath the Fivemile Pass nappe. Secondary folds in the Mercur limestone member and Manning Canyon Shale trend southeastward. Three main northeast-trending, steep-dipping tear faults segment the nappe into two main blocks. Imbricate thrusts emplace Manning Canyon Shale over the younger parts of the Mercur limestone member near the south end of the nappe. Several steep-dipping normal faults do not greatly offset the sedimentary rocks.

Folds above the Clay thrust are evenly spaced, broad, with low amplitude, and are symmetrical in cross section. These were formed in a thinned, less competent leading edge of this thrust plate. However, locally in the in the upper plate of the imbricate thrust lying between the Sunshine (boundary) and Fivemile tear faults, east-northeast-trending folds in the Mercur limestone are tight and asymmetrical. The east-southeast-trending, low amplitude, open folds in Manning Canyon Shale and Mercur limestone member of the Great Blue Limestone are on the upper plate of the imbricate Wells thrust fault, east of the Fivemile Pass tear fault.

The sole Clay thrust fault, fault imbrications in the upper plate, and tear and normal faults are the main structures in the Fivemile Pass nappe. The Clay thrust is a relatively steep-dipping fault, judging by its trend across the topography and lack of asymmetrical or overturned folds. Upper-plate folds are offset progressively along the northeast trending Fivemile and Cedar tear faults. These tear faults are steep dipping, northnortheast trending, mostly with only relatively small apparent displacement within the nappe. An overlying imbricate Wells thrust places younger Manning Canyon Shale over the Mercur limestone member east of the Fivemile fault. Mercur limestone reappears at the south end of the range by sedimentary succession and normal faulting. The impact of Basin and Range extensional faulting is presumed but apparently is not as marked here as in the adjoining Bingham nappe.

\section{Location and Types of Igneous Rocks}

No igneous rocks have been observed in the nappe. Several small breccia pipes, possibly of igneous origin, intrude the Great Blue Limestone in the Sunshine mining area, near the boundary of the Bingham and Fivemile Pass nappes (Tooker, 1987). The pipes contain angular fragments of altered limestone and rhyolite porphyry(?). The largest breccia pipe (61 x 183 m), which occurs in Clay Canyon northeast of Sunshine (Tooker, 1987), has been extensively altered in part to clay minerals.

\section{Associated Mineral Resources}

There is no evidence of the occurrence of base and precious metal deposits in the nappe. Economic brick-clay deposits and the semiprecious mineral variscite were mined in the Wells and Clay Canyon areas and along the south end of the Oquirrh Mountains in the Fivemile Pass area (Ornelas 1953; and Hyatt, 1956).

The clay deposits occur in the relatively thick, altered shale horizons of the Mercur limestone member of the Great Blue Limestone in Wells Canyon. The clay layers in the interbedded shale units range in thickness from 8 to $15 \mathrm{~m}$, from light gray to dark gray in color, and with thin interbedded red and yellow iron-stained oxide bands and layers. The plastic noncalcareous, greenish-gray to black, and iron-stained clay-rich zone is overlain by medium-bedded to massive, medium-gray limestone. Production data of mined clay materials are unavailable.

Hamilton (1959) and Sinkankas (1976) described the occurrence of variscite, originally discovered in 1890 in the massive overlying beds of the Great Blue Limestone in Clay Canyon. The shale-rich horizon is overlain by massive, medium-bedded, dark-gray to black limestones. Where brecciated locally in Clay Canyon, the limestones contain small deposits of the nodular semi-precious gem mineral variscite, $\left(\mathrm{Al}\left(\mathrm{PO}_{4}\right) 2 \mathrm{H}_{2} \mathrm{O}\right)$. The mineral is believed to form by seepage of phosphate-impregnated waters through aluminous rocks to form seams and crevices along shear and fracture zones. Cryptocrystalline quartz accompanies the variscite as chalcedony veinlets or chert, and the nodules are generally oval, flattened, and embedded in a matrix of quartz and calcite. The color of variscite varies from "light to dark shades of rich yellowish green, but very pale to almost white shades are known as well as those of purest deep green" (Sinkankas, 1976, p. 230). The source, time, and place of impregnation of phosphate waters are not known. Production of variscite peaked in 1909-1911, resulting in thousands of pounds. Since that time production has been sporadic, the last known production was in 1942. These deposits are not accessible today.

Quaternary sand and gravel deposits are also abundant and mined in the Fivemile Pass area. Their production has been intermittent and the amount taken is not known.

\section{Conclusions}

Analysis of detailed geologic mapping, stratigraphic and paleontological studies, and evaluation of the rock structures in north-central Utah, as well as consideration of previous geological research in the area, are the bases for a revised regional geologic setting for the Oquirrh Mountains and the occurrence of its ore deposits. Five nappes, which constitute the range, are defined on the basis of their fossiliferous carbonate and quartz-rich sedimentary rocks and their individually distinctive fold and fault structures. These data provide a fundamental basis for reconstructing the geologic evolution of north central Utah and a rationale for the location of base and precious metal ore deposits in the Oquirrh Mountains. 
The geologic analysis begins with recognition of the accretion of a Proterozoic sedimentary terrane onto the Wyoming Archean craton, and the creation of a basement buttress locally in the Wasatch Mountains east of Salt Lake City, Utah. The buttress overlies an earlier formed, west-trending mobile Uinta trend basement lineament. During the Paleozoic, sediments were eroded from the craton and deposited in the western hinterland in the Oquirrh and Sublette Basins, which were separated by a then uplifted part of the Uinta trend. Thrust faults produced by the Cretaceous Sevier Orogeny moved five Paleozoic nappe terranes eastward from their hinterland toward a foreland craton buttress. Tertiary igneous activity occurred locally in the stressed leading edge of nappe thrusts in the Oquirrh Mountains where uplifted and faulted along the Uinta trend. Hydrothermal activity in and about the intrusive stocks produced disseminated copper-molybdenum-gold and base- and precious-metal skarn, vein, and replacement deposits in thrust-faulted Paleozoic sedimentary rock nappes in the Bingham, Ophir, Mercur, and Stockton mining districts. Subsequent Basin and Range faulting defined the present Oquirrh Mountains terrane. Cenozoic uplift and erosion along the trend produced material for extensive sand and gravel deposits, particularly in those parts of Pleistocene Lake Bonneville that overlay the trend.

This revised regional geologic model provides an innovative understanding of the origin of the entire Oquirrh Mountains and its important ore deposits. These data also provide a coherent basis for evaluating the geology of north central Utah.

\section{Acknowledgments}

Knowledge of the geology of the Oquirrh Mountains has evolved during more than 130 years, and each step along the way was made possible owing to the dedication, ingenuity, and persistent efforts of a long list of previous investigators. Earlier USGS and mining company studies of the range and its mining districts by J.E. Spurr, J.M. Boutwell, J.J. Beeson, B.S. Butler, R.N. Hunt, and James Gilluly provide much of the historical background as well as early geological interpretations on which this survey is built. Growing recognition of the complex geology of the range still challenges us today.

Ralph J. Roberts conceived and organized the Oquirrh Mountains studies reported here, but he was called away, midway, to develop a USGS heavy metals program, entrusting me to complete our studies of the range. His keen scientific understanding and enthusiasm set the direction and tone for the project and this report.

I gratefully acknowledge the assistance and encouragement of USGS colleagues W.J. Moore, J.A. Briskey, Jr., R.W. Kopf, T.L. Vercoutere, and D.B. Vander Meulen for their geologic mapping and structural and stratigraphic interpretations. W.J. Moore and E.H. McKee classified and dated the igneous rocks. Mackenzie Gordon, Jr., R.C. Douglass, M.E. Taylor, E.L. Yochelson, H.M. Duncan, J.T. Dutro, Jr., K.S. Schindler, S.H. Mamay, and W. J. Sando made the paleontologic identi- fications, indicated the chronology of sedimentary rocks, and made regional stratigraphic correlations. D.R. Mabey conducted geophysical investigations in the range.

I also wish to acknowledge the published company-sponsored geologic studies in the Bingham mining district. These include contributions by A.H. James, W.H. Smith, George Lanier, W.C. Peters, R.E. Bray, A.J. Swensen, B.F. Stringham, J.E. Welsh, R.C. Babcock, G.H. Ballantyne, C.H. Phillips, R.D. Presnell, and J.E. Reid of Kennecott; those by H.G. Peacock, M.T. Einaudi, W.W. Atkinson, Jr, and W.J. Garmoe of the former Anaconda Minerals Company and the assistance of R.N. Hunt, R.D. Rubright, and O.J. Hart of U.V. Industries (formerly the U.S. Smelting, Refining, and Mining Company). I also thank L.D. Kornze, W.J. Tafuri, Tracy Shrier, T.B. Faddies, R.G. Blair, and S.B. Kerr of American Barrick (formerly Getty Mining) for field visits, conferences, and published data on the geology of the Mercur mining district. Thanks to F.W. Bauman, Touchstone Resources for data on the Sunshine mining area. The reports by W.L. Gunter, J.W. Hammitt, R.C. Babcock, Jr., and T.R. Gibson of the Kennecott Corporation and Kennecott Exploration Company were also very helpful, R.D. Presnell, University. of Utah, and the recent summary by R.C. Babcock, Jr., G.H. Ballantyne, and C.H. Phillips of Kennecott are the main recent sources of information about the Barneys Canyon mines.

Permission for entrance of USGS personnel onto privately controlled lands by the television transmission, livestock grazing, and mining companies is also acknowledged with appreciation. Other contributions of data on the geology and ore deposits in the Oquirrh Mountains, which were derived from a number of university and individuals' studies and those by Tooker (1998), Gordon, Tooker and Dutro, (2000), and Tooker and Roberts (1998) are summarized in this report. I am very indebted to Donald Mabey and Dennis Cox for their incisive reviews of this manuscript. The geologic conclusions and interpretations in this report, derived from my data and from those listed above are the responsibility of the author.

\section{References Cited}

Allmendinger, R.W., and Jordan, T.E., 1981, Mesozoic evolution, hinterland of the Sevier orogenic belt: Geology, v. 9, no. 7 , p. 308-313.

Allmendinger, R.W., and Jordan, T.E., 1984, Mesozoic structure of the Newfoundland Mountains, Utah: Horizontal shortening and subsequent extension in the hinterland of the Sevier belt: Geological Society of America Bulletin, v. 95, no. 11 , p. 1280-1292.

Allmendinger, R.W., Sharp, J.W., Von Tish, Douglas, Serpa, Laura, Brown, Larry, Kaufman, Sidney, Oliver, Jack, and Smith, R.B., 1983, Cenozoic and Mesozoic structure of the eastern Basin and Range province, Utah, from COCORP seismic-reflection data: Geology, v. 11, no. 9, p. 532-536. 
Anderson, R.E., Zoback, M.L., and Thompson, G.A., 1983, Implications of selected subsurface data on the structural form and evolution of some basins in the northern Basin and Range province, Nevada and Utah: Geological Society of America Bulletin, v. 93, no. 9, p. 1055-1072.

Arehart, G.B., Christensen, J.N., McInnes, B.A., and Donnelikck, R.A. 2003, Evaluation of radioisotope dating of Carlin-type deposits in the Great Basin, Western North America, and implications for deposit genesis: Bulletin of Economec Geology, v. 98, no.2, p. 235-248.

Armstrong, R.L., 1968a, The Cordilleran miogeosyncline in Nevada and Utah: Utah Geological and Mineral Survey, Bulletin. 78, p. 429-458.

Armstrong, R.L., 1968b, Sevier orogenic belt in Nevada and Utah: Geological Society of America Bulletin, v. 79, no. 4, p. 429-458.

Armstrong, R.L., 1970, Geochronology of Tertiary igneous rocks, eastern Basin and Range province, western Utah, eastern Nevada, and vicinity, U.S.A.: Geochemica et Cosmochemica Acta, v. 34, p. 203-232.

Armstrong, R.L., 1972, Low-angle (denudation) faults, hinterland of the Sevier orogenic belt, eastern Nevada and western Utah: Geological Society of America Bulletin, v. 83, no. 6, p. 1729-1754.

Armstrong, R.L., Ekren, E.B., McKee, E.H., and Noble, D.C., 1969, Space-time relations of Cenozoic silicic volcanism in the Great Basin of the western United States: American Journal of Science, v. 267, p. 478-490.

Armstrong, F.C. and Oriel, S.S., 1965, Tectonic development of Idaho-Wyoming thrust belt: American Association of Petroleum Geologists Bulletin, v. 49, p. 1847-1866.

Atkinson, W.W., Jr., and Einaudi, M.T., 1978, Skarn formation and mineralization in the contact aureole at Carr Fork, Bingham, Utah: Economic Geology, v. 73, no. 7, p. 1326-1365.

Babcock, R.C., Jr., Ballantyne, G.H., and Phillips, C.H., 1995, Summary of the geology of the Bingham mining district, Utah, in The Cordillera Symposium, Porphyry Copper Deposits from Alaska to Chile, October 5-7, 1994, Tucson, Arizona, 19 p. 316-335.

Babcock, R.C., Jr., Ballantyne, G.H., and Phillips, C.H., 1997, Summary of the geology of the Bingham district, Utah, in John, D.A. and Ballantyne, G.H., eds., Geology and ore deposits of the Oquirrh and Wasatach Mountains, Utah: Guidebook v. 29, Society of Economic Geologists, p. 113-132.

Bankey, Viki, and Campbell, D.L., 1989, Status of geophysical data base, in Stein, H.J., Bankey, Viki, Cunningham, C.G., Zimbelman, D.R., Brickey, D.W., Shubat, Michael, Campbell, C.G., and Podwysocki, M.H., Tooele $1 \times 2$ degree quadrangle, northwest Utah--CUSMAP preassessment study: U.S. Geological Survey Open-File Report 89-467, p. 46-59.
Baker, A.A., Huddle, J.W., and Kinney, D.M., 1949, Paleozoic geology of north and west sides of Uinta Basin, Utah: American Association of Petroleum Geologists Bulletin, v. 33, no. 7, p. 1161-1197.

Baker, A.A. and Crittenden, M.D. Jr., 1961, Geology of the Timpanogos Cave Quadrangle, Utah: U.S. Geological Survey Geologic Quadrangle Map 132, scale 1:24,000.

Beeson, J.J., 1917, Disseminated copper ores of Bingham Canyon, Utah: American Institute of Mining Engineers Transactions, v. 54, p. 356-401.

Beeson, J.J., 1925, Mining districts and their relation to structural geology: American Institute of Mining Metallurgical Engineers Transactions (reprint) no. 1500, 36 p.

Beutner, E.C., 1977, Causes and consequences of curvature in the Sevier orogenic belt, Utah to Montana: Wyoming Geological Association Guidebook, 29th Annual Field Conference--1977, p. 353-365.

Blick, N.H., 1979, Stratigraphic, structural and paleogeographic interpretation of upper Proterozoic glaciogenic rocks in the Sevier orogenic belt, southwestern Utah: Santa Barbara, University of California, Ph.D. dissertation, 636 p.

Bowman, J.R., Parry, W.T., Kropp, W.P., and Kruser, S.A., 1987, Chemical and isotopic evolution of hydrothermal solutions at Bingham, Utah: Economic Geology, v. 82, no. 2, p. 395-428.

Boutwell, J.M., 1905a, Economic geology of the Bingham mining district, Utah [with sections by A. Keith and S.F. Emmons]: U.S. Geological Survey Professional Paper 38, $413 \mathrm{p}$.

Boutwell, J.M., 1905b, Genesis of the ore deposits at Bingham, Utah: American Institute of Mining Engineers Transactions, v. 36, p. 541-580.

British Petroleum Company, 1986, Financial and operating information, 1982-1986: Cleveland, Ohio, BP America Inc., p. 112-114.

Bray, R.E., 1969, Igneous rocks and hydrothermal alterationat Bingham, Utah: Economic Geology, v. 64, no .1, p. 34-49.

Bray, R.E., Lanier, George, and John, E.C., 1975, General geology of the open-pit mine, in Bray, R.E., and Wilson, J.C. eds., Guidebook to the Bingham mining district: Bingham Canyon, Utah, Kennecott Copper Corporation, p. 49-58.

Brooks, J.E., 1956, Middle Paleozoic tectonic history of northcentral and northwestern Utah [abs.]: Journal of Paleontology, v. 30, no. 4, p. 1009.

Bryant, Bruce, 1979, Reconnaissance geologic map of the Precambrian Farmington Canyon Complex and surrounding rocks in the Wasatch Mountains between Ogden and Bountiful, Utah: U.S. Geological Survey Open-File Report 79-709, scale 1:50,000. 
Bryant, Bruce, 1993, Wasatch Mountains and Antelope Island, in, Houston, R.S., ed., The Wyoming province, in Reed, J.C., Jr. and others, eds., Precambrian-Conterminous U.S.: Geological Society of America, The geology of North America, D.N.A.G. v. C-2, p. 149-151.

Bryant, Bruce and Nichols, D.J., 1988, Late Mesozoic and early crustal boundaries along the Uinta trend and its interaction with the Sevier orogenic belt, in, Schmidt, C.J. and Perry, W.J., Jr. eds., Interaction of the Rocky Mountains foreland and the Cordilleran thrust belt: Geological Society of America Memoir 171, p. 411-430.

Butler, B.S., 1920, Oquirrh Range, in Butler, B.S., Loughlin, W.C., and Heikes, V.C., The ore deposits of Utah: U.S. Geological Survey Professional Paper 111, p. 335-395.

Butler, B.S., Loughlin, G.F. , and Heikes, V.C., 1920, The ore deposits of Utah: U.S. Geological Survey Professional. Paper 111, 672 p.

Cameron, D.E., and Garmoe, W.J., 1983, Distribution of gold in skarn ores of the Carr Fork mine, Tooele, Utah: Economic Geology, v. 82, no. 5, p. 1319-1333.

Camilleri, P.A., Miller, D.M., Snoke, A.W., and McGrew, A.J., 1994, Mesozoic metamorphic architecture of the hinterland of the Sevier fold-and-thrust belt, Northeast Nevada [abs.] Abstracts with Programs - Geological Society of America, in Geological Society of America Cordilleran Section, 90th annual meeting, v. 26, no. 2., February 1994, p. 43.

Coats, R.R., 1987, Geology of Elko County, Nevada: Nevada Bureau of Mines and Geology, Bulletin 101, 12 p.

Compton, R.R., 1983, Displaced Miocene rocks on the west flank of the Raft River-Grouse Creek core complex, Utah: Geological Society of America, Memoir 157, p. 271-279.

Condie, K.C., 1969, Geologic evolution of the Precambrian rocks in northern Utah and adjacent areas, in Jensen, M.L., ed., Guidebook of northern Utah: Utah Geological and Mineralogical Survey Bulletin, v. 82, p. 71-95.Cook, D.R., ed., 1961, Geology of the Bingham mining district and northern Oquirrh Mountains, Utah: Utah Geological Society Guidebook to the geology of Utah, v. 16, $145 \mathrm{p}$.

Cook, K.L., and Berg, J.W., Jr., 1961, Regional gravity survey along the central and southern Wasatch Front, Utah: U.S. Geological Survey Professional Paper 316-E, p. E75-E89.

Cook, K.L., Halverson, M.D., Stepp, J.C., and Berg, J.W., Jr., 1964, Regional gravity survey of the northern Great Salt Lake Desert and adjacent areas in Utah, Nevada and Idaho: Geological Society of America Bulletin, v. 75, p. 715-740.

Cook, K.L., Berg, J.W., Jr., Johnson, W.W., and Novotny, R.T., 1966, Some Cenozoic structural basins in the Great Salt Lake area, Utah, indicated by regional gravity surveys, in Stokes, W.L., ed., The Great Salt Lake: Utah Geological Society, Guidebook to the Geology of Utah, v. 20, p. 57-75.
Crittenden, M.D., Jr., 1959, Mississippian stratigraphy of the central Wasatch and western Uinta Mountains, Utah: Intermountain Association of Petroleum Geologists Guidebook, 10th Annual Field Conference, p. 63-74.

Crittenden, M.D., Jr., 1961, Magnitude of thrust faulting in northern Utah: U.S. Geological Survey Professional. Paper 424-D, p. D128-D131.

Crittenden, M.D., Jr., 1963, New data on the isostatic deformation of Lake Bonneville: U.S. Geological Survey Prof. Paper 454-E, $31 \mathrm{p}$.

Crittenden, M.D., Jr., 1976, Stratigraphy and structural setting of the Cottonwood area, Utah, in Hill, J.G., ed., Geology of the Cordilleran hingeline: Denver, Colo., Rocky Mountain Association of Geologists-1976 Symposium, p. 363-379.

Crittenden, M.D., Jr., Granger, A.E., Sharp, B.J., and Calkins, F.C., 1952, Geology of the Wasatch Mountains east of Salt Lake City: Utah Geological Society, Guidebook to the geology of Utah, v. 8, p. 1-37.

Cross, T.A., 1986, Tectonic controls of foreland basin subsidence and Laramide style deformation, western United States, in Allen, P.A., and Homewood, S.P., eds., Foreland basins: International Association of Sedimentologists Special Publication 8, p. 15-39.

Davis, G.E., 1979, Problems of intraplate extensional tectonics, western United States, with special emphasis on the Great Basin, in Newman, G.W. and Goode, H.D., eds., Basin and Range Symposium and Great Basin field conference, 1976: Denver, Colo., Rocky Mountain Association of Geologists, p. 41-54.

Davis, L.E., and Webster, G.D., 1987, Conodont biostratigraphy of the Lake Point Limestone and recognition of the Mississippian/Pennsylvanian boundary and a potential Morrowan stratotype, in Abstracts with programs, 1987: Rocky Mountain Section, Geological Society of America, p. 269.

Davis, L.E., Webster, G.D., and Dyman, T.S., 1994, Correlation of the West Canyon, Lake Point, and Bannock Peak Limestones (Upper Mississippian to Middle Pennsylvanian), basal formations of the Oquirrh Group, northern Utah and southeastern Idaho: U.S. Geological Survey Bulletin 2088, $30 \mathrm{p}$.

DeCelles, P.G., Lawton, T.F., and Mitra, Gautam, 1995, Thrust timing, growth of structural culminations, and synorogenic sedimentation in the type Sevier orogenic belt, western United States: Geology, v. 23, no. 8, p. 699-702.

Eardley, A.J., Gvosdetsky, Vasyl, and Marsell, R.E., 1957, Hydrology of Lake Bonneville and the sediments and soils of the basin [Utah]: Geological Society of America Bulletin, v. 68 , no. 9 , p. $1141-1201$. 
Eaton, G.P., 1979, Regional geophysics, Cenozoic tectonics, and geologic resources of the Basin and Range province and adjoining regions, in Newman, G.W. and Goode, H.D., eds., Basin and Range symposium and Great Basin field conference: Denver, Colo., Rocky Mountain Association of Geologists, p. 11-40.

Eaton, G.P., 1982, The Basin and Range province: origin and tectonic significance: Annual Reviews of Earth and Planetary Sciences, v. 10, p. 409-440.

Eaton, G.P., Wahl, R.R., Prostka, H.J., Mabey, D.R., and Kleinkopf, M.D., 1978, Regional gravity and tectonic patterns--their relation to late Cenozoic epeirogeny and lateral spreading in the western Cordillera, in Smith, R.B., and Eaton, G.P., eds., Cenozoic tectonics and regional geophysics of the western Cordillera: Geological Society of America Memoir 152, p. 51-91.

Einaudi, M.T., 1975, Iron metasomatism of sedimentary rocks near the Bingham stock, in Bray, R.E., and Wilson, J.C., eds., Guidebook to the Bingham mining district, Society of Economic Geologists, October 23, 1975: Bingham Canyon, Utah, Kennecott Copper Corporation, p. 135-139.

Einaudi, M.T., 1983, General features and origin of skarns associated with porphyry copper plutons, in Titley, S.R., ed. Advances in geology of the porphyry copper deposits: The University of Arizona Press, Tucson, Ariz., p. 139-184.

Erickson, A.J., Jr., 1976, The Uinta-Gold Hill trend; an economically important lineament, in Utah Geological Association Proceedings of the First International Conference on the New Basement Tectonics: Utah Geological Association Publication, no. 5, p. 126-137.

Faddies, T.B., and Kornze, L.D., 1985, Economic geology of the Mercur district, Utah: Tooele, Utah, Getty Mining Company, unpub. report, $25 \mathrm{p}$.

Farmer, G.L. and DePaulo, D.J., 1983, Origin of Mesozoic and Tertiary granites in the western United States and implications for pre-Mesozoic crustal structure-1. $\mathrm{Nd}$ and $\mathrm{Sr}$ isotopic studies in the geocline of the northern Great Basin: Journal of Geophysical Research, v. 88, n. B4, p. 33793401.

Field, C.W., 1966, Sulfur isotope abundance data, Bingham district, Utah: Economic Geology, v. 61, no. 5, p. 850-871.

Field, C.W., and Moore, W.J., 1971, Sulfur isotope study of the "B" limestone and Galena Fissure ore deposits of the U.S. mine, Bingham mining district, Utah: Economic Geology, v. 66, no. 11, p. 48-62.

Gilbert, G.K., 1886, Lake Bonneville: U.S. Geological Survey Monograph 1, $438 \mathrm{p}$.

Gilbert, G.K., 1928, Studies of Basin-Range structure: U.S. Geological Survey Professional Paper 153, 89 p.
Gillespie, J.M., and Heller, P.L., 1995, Beginning of foreland subsidence in the Columbian-Sevier belts, southern Canada and northwest Montana: Geology, v. 23, no. 8, p. 723-726.

Gilluly, James, 1928, Basin Range faulting along the Oquirrh Range, Utah: Geological Society of America Bulletin, v. 39, p. 1103-1130.

Gilluly, James,, 1932, Geology and ore deposits of the Stockton and Fairfield Quadrangles, Utah: U.S. Geological Survey Professional Paper 173, 171 p.

Gordon, Mackenzie, Jr., and Duncan, H.M., 1970, Biostratigraphy and correlation of the Oquirrh Group and related rocks in the Oquirrh Mountains, Utah, in Tooker E.W. and Roberts, R.J., Upper Paleozoic rocks in the Oquirrh Mountains and Bingham mining district, Utah: U.S. Geological Survey Professional Paper 629-A, p. A38-A69.

Gordon, Mackenzie, Jr., Tooker, E.W., and Dutro, J.T., Jr., 2000, Geology of the type locality for the Great Blue Limestone in the Oquirrh Mountains, Utah: U.S. Geological Survey Open-File Report 00-012, 61 p.

Guenther, E.M., 1973, The economic geology of the Mercur gold camp, Utah: Salt Lake City, University of Utah, M.S. thesis, $79 \mathrm{p}$.

Gunter, W.L., Hammitt, J.W., Babcock, R.C., Gibson, T.R., and Presnell, R.D., 1990. Geology of the Barneys Canyon and Melco gold deposits, Salt Lake County, Utah: in Hausen, D.M., ed., Gold 90--Proceedings of the Gold '90 symposium, Salt Lake City, Utah: Littleton, Colo., Society for Mining, Metallurgy, and Exploration, p. 41-50.

Gunter, W.L. and Austin, W.L., 1997, Geology of the Melco gold eeposit, Oquirrh Mountains, Utah, in John, D.A. and Ballantyne, G.H., Geology and ore deposits of the Oquirrh and Wasatch Mountains, Utah: Guidebook of the Society of Economic Geologists Field Conference, Oct. 1997, v. 29, p. 331-338.

Hamilton, H.V., 1959, Variscite and associated minerals of Clay Canyon, Utah: Mineralogical Society of Utah Bulletin, v. 9, no. 1, p. 13-17.

Hamilton, Warren, and Meyers, W.B., 1966, Cenozoic tectonics of the western United States: Reviews of Geophysics, v. 4 , no. 4 , p. 509-549.

Hammond, E.D., 1961, History of mining in the Bingham district, Utah, in Cook, D.R., ed., Geology of the Bingham mining district and northern Oquirrh Mountains: Utah Geological Society Guidebook to the geology of Utah, no. 16 , p. $120-129$.

Hansen, L.A., 1961, The stratigraphy of the Carr Fork Mine, Bingham district, Utah, in Cook, D.R., ed., Geology of the Bingham mining district and northern Oquirrh Mountains, Guidebook to the Geology of Utah, no. 16, p. 71-81. 
Hansen, A.R. and McCarley, L.A., 2000, Antelope Island, New evidence for thrusting, in King, J.K. and Willis, G.C., eds., The geology of Antelope Island, Davis County, Utah: Utah Geological Survey, Miscellaneous Publication 00-1, p. $1-5$.

Heller, P.L., Bowdler, S.S., Chambers, H.P., Coogan, J.C., Hagen, E.S., Schuster, M.W., Winslow, N.S., and Lawton, T. F., 1986, Time of initial thrusting in the Sevier orogenic belt, Idaho-Wyoming and Utah: Geology, v. 14, no. 5, p. 388-391.

Heller, P.L, and Paola, Chris, 1989, The paradox of Lower Cretaceous gravels and the initiation of thrusting in the Sevier orogenic belt, United States Western Interior: Geological Society of America Bulletin, v. 100, no. 6, p. 864-8.

Henstock, T.J., Levander, Alan, Snelson, C.M., Keller, G.R., Miller, K.C., Harder, S.H, Gorman, A.R., Clowes, R.M., Burianyk, M.J.A., and Humphreys, E.D., 1998, Probing the Archean and Proterozoic lithosphere of western North America: G.S.A. Today, v. 8, n. 7, p. 1-5.

Hintze, L.F., 1973, Geologic history of Utah: Brigham Young University geology studies, v. 20, pt. 3, Studies for students, no. $8,181 \mathrm{p}$.

Hunt, R.N., 1924, The ores in the limestones at Bingham, Utah: American Institute of Mining and Metallurgical Engineers Transactions, v. 70, p. 856-883.

Hunt, R.N., 1933, Excursion 2, Bingham mining district, in Boutwell, J.N., The Salt Lake region: International Geological Congress, XVI session, United States, 1933, Guidebook 17, Excursion C-1, p. 45-56.

Hunt, J.P., 1957, Rock alteration, mica, and clay minerals in certain areas in the United States and Lark mines, Bingham, Utah: Berkeley, University of California, Ph.D. dissertation, $321 \mathrm{p}$.

Hyatt, E.P., 1956, Clays of Utah County, Utah: Utah Geological and Mineral Survey Bulletin, no. 55, 83 p.

James, A.H., Smith, W.H., and Welsh, J.E., 1961a, General geology and structure of the Bingham district, Utah, in Cook, D.R., ed., Geology of the Bingham mining district and northern Oquirrh Mountains: Utah Geological Society, Guidebook to the geology of Utah, no. 16, p. 49-70.

James, A.H., Smith, W.H., and Bray, R.E., 1961b, The Bingham district--a zoned porphyry ore deposit, in Cook, D.R., ed., Geology of the Bingham mining district and northern Oquirrh Mountains: Utah Geological Society, Guidebook to the geology of Utah, no. 16, p. 82-100.

James, L.P., 1978, The Bingham copper deposits, Utah, as an exploration target: History and pre-excavation geology: Bulletin of Economic Geology, v. 73, no. 7, p. 1215-1217.
James, L.P., 1982, Sulfide ore deposits related to thrust faults in northern Utah, in Nielson, D.R., ed., Overthrust belt of Utah--1982 symposium and field conference: Utah Geological Association Publication no. 10, p. 91-100.

Jewell, P.W., 1984, Chemical and thermal evolution of hydrothermal alteration of the Mercur gold district, Tooele County, Utah: Salt Lake City, Universty of Utah, unpub. M.S. thesis.

Jewell, P.W., and Parry, W.T., 1987, Geology and hydrothermal alteration of the Mercur gold deposit: Economic Geology, v. 82, no. 7, p. 1958-1966.

Jewell, P.W., and Parry, W.T., 1988, Geochemistry of the Mercur gold deposit, Utah (U.S.A.): Chemical Geology, v. 69 , no. $3 / 4$, p. $245-266$.

John, E.C., 1978, Mineral zones in the Utah Copper orebody: Bulletin of Economic Geology, v. 73, n. 7, p. 1250-1269.

John, D.A., 1989, Geologic setting, depths of emplacement, and regional distribution of fluid inclusions in intrusions of the cerntral Wasatch Mountains, Utah: Bulletin of Economic Geology, v. 84, n. 2, p. 386-409.

Jordan, T.E., 1983, Structural geometry and sequence, Bovine Mountain, northwest Utah, in Miller, D.M., Todd, V.R., Howard, K.A., eds., Tectonic and stratigraphic studies in the eastern Great Basin: Geological Society of America Memoir 157 , p. 215-228.

Jordan, T.E., and Douglas, R.C., 1980, Paleogeography and structural development of the Late Pennsylvanian to Early Permian Oquirrh basin, northwestern Utah, in Fouch, T.D., and Magathan, E.R., eds., Paleozoic paleogeography of west-central United States: Society of Economic Paleontologists and Mineralogists, p. 217-238.

Kennecott geologic staff, compilers, 1991, Geologic map of the Bingham district [Utah], scale 1:24,000.

Kerr, S.B., 1997, Geology of the Mercur gold mine, Oquirrh Mountains, Utah, in John, D.A., and Ballantyne, G.H., eds., Geology and ore deposits of the Oquirrh and Wasatch Mountains, Utah Littleton, CO, Society of Economic Geologists field conference, October 1997, guidebook 29, p. 349-369.

King, P.B., 1976, Precambrian geology of the United States-an explanatory text to accompany the Geologic Map of the United States: U.S. Geological Survey Professional Paper 902, 85 p.

King, P.B., and Beikman, H.L., 1974, Geologic map of the United States: U.S. Geological Survey, scale 1:5,000,000.

Kistler, R.W., and Peterman, Z.E., 1978, Reconstruction of crustal blocks of California on the basis of initial strontium isotopic compositions of Mesozoic granitic rocks: U.S. Geological Survey Professional Paper 1071, 17 p. 
Klatt, H.R. and Tafuri, W.J.,1976, Gold mineralization in the Mercur mining district, Utah: Northwest Mining Association Proceedings, December, 1976, Spokane, Wash.

Konopka, E.H., and Dott, R.H., Jr., 1982, Stratigraphy and sedimentology, lower part of the Butterfield Peaks Formation (Middle Pennsylvanian), Oquirrh Group, Mt. Timpanogos, Utah: Utah Geological Association Publication 10, p. 215-234.

Kornze, L.D., 1984, Geology of the Mercur gold mine, in Johnson, J.L., ed., Bulk mineable precious metal deposits in the western United States: Guidebook for fieldtrips, Geological Society of Nevada, Reno, NV, p. 381-389.

Kornze, L.D., Faddies, T.B., Goodwin, J.C., and Bryant, M.A., 1985, Geology and geostatistics applied to grade control at the Mercur gold mine, Mercur, Utah: in Erickson, A.J., Jr., Metz, R.A. and Ranta, D.E., eds., Applied mining geology, Littleton, CO, Society of Mining, Metallurgy, and Exploration, p. 45-56

Krahulac, K.A., 1997, History and production of the West Mountains (Bingham) mining district, Utah: in Johns, D.A. and Ballantytne, G.H., eds, Geology and ore deposits of the Oquirrh and Wasatch Mountains, Utah: Guidebook of the Society of Economic Geologists, field conference, Oct. 1997, p. 189-218.

Lanier, George, compiler, 1978a, Geologic map of the Bingham mine, Bingham Canyon, Utah, in Lanier and others, General geology of the Bingham mine, Bingham Canyon, Utah: Kennecott Copper Corporation, Utah Copper Division, Bingham Canyon, Utah, scale 1:9600.

Lanier, George, John, E.C., Swensen, A.J., Reid, J.E., Bard, C.E., Caddy, S.W., and Wilson, J.C., 1978b, General geology of the Bingham mine, Bingham Canyon, Utah: Economic Geology, v. 73, no. 7, p. 1228-1241,

Lawton, T.F., Talling, F.J., Hobbs, R.S., Trexler, J.H., Jr., Weiss, M.P., and Burbank, D.W., 1993, Structure and stratigraphy of Upper Cretaceous and Paleogene strata (North Horn Formation), eastern San Pitch Mountains, UtahSedimentation at the front of the Sevier orogenic belt: U.S. Geological Survey Bulletin 1787, p. II1-II33.

Lenzi, G.E., 1971, Geochemical reconnaissance at Mercur, Utah: Utah Geological and Mineral Survey, Special Studies, 43, $16 \mathrm{p}$.

Levy, Marjorie, and Christie-Blick, Nicholas, 1989, PreMesozoic palinspastic reconstruction of the Eastern Great Basin (Western United States): Science, v. 245, no. 4925, p. 1454-1462.

Lufkin, J.L., 1965, Geology of the Stockton stock and related intrusives: Brigham Young University research studies, Geologic series, v. 12, p. 149-164,

Mabey, D.R., 1960, Regional gravity survey of part of the Basin and Range province: U.S. Geological Survey Professional Paper 400B, p. B282-285.
Mabey, D.R., Crittenden, M.D., Jr., Morris, H.T., Roberts, R.J., and Tooker, E.W., 1964, Aeromagnetic and generalized geologic map of part of North-Central Utah: U.S. Geological Survey Geophysical Investigations Map GP-422, scale $1: 250,000$.

Mabey, D.R., Tooker, E.W., and Roberts, R.J., 1963, Gravity and magnetic anomalies in the northern Oquirrh Mountains, Utah: U.S. Geological Survey Professional Paper 450-E, p. E28-E31.

Mabey, D.R., Zeitz, Isidore, Eaton, G.P., and Kleinkopf, M.D., 1978, Regional magnetic patterns in part of the Cordillera of the western United States, in Smith, R.B., and Eaton, G.P., Cenozoic tectonics and regional geophysics of the western Cordillera: Geological Society of America Memoir 153, p. 93-106.

Melker, M.D., and Keith, J.D., 1997, Paleomagnetism of the Oquirrh Mountains and implications for the Cenozoic structural history of the easternmost Great Basin, in Johns, D.A. and Ballantyne, G.H., eds., Geology and ore deposits of the Oquirrh and Wasatch Mountains, Utah, Guidebook of the Society of Economic Geologist, Oct. 1997, p. 141-158.

Miller, D.M., 1983, Allochthonous quartzite sequence in the Albion Mountains, Idaho, and proposed Proterozoic $\mathrm{Z}$ and Cambrian correlatives in the Pilot Range, Utah and Nevada, in Miller, D.M., Todd, V.R., Howard, K.A., eds., Tectonic and stratigraphic studies in the eastern Great Basin: Geological Society of America Memoir 157, p. 191-214.

Miller, D.M., and Hoisch, T.D., 1995, Jurassic tectonics of northeastern Nevada and northwestern Utah from the perspective of barometric studies, in Miller, D.M., and Busby, Cathy, eds., Jurassic magmatism and tectonics of the North American Cordillera: Geological Society of America Special Paper 299, p. 267-294.

Mineral Resources Data System (MRDS), 1990-91, U.S. Geological Survey, Branch of Resource Analysis (BORA) computer database: U.S. Geological Survey, Reston, VA.

Moore, W.J., 1973a, Preliminary geologic map of the western Traverse Mountains, Salt Lake and Utah Counties, Utah: U.S. Geological Survey Miscellaneous Field Studies Map MF-490, scale 1:24,000.

Moore, W.J., 1973b, Igneous rocks in the Bingham mining district, Utah: U.S. Geological Survey Professional Paper 629-B, 42 p.

Moore, W.J., 1973c, A summary of radiometric ages of igneous rocks in the Oquirrh Mountains, north central Utah: Economic Geology, v. 68, no. 1, p. 97-101.

Moore, W.J., 1978, Chemical characteristics of hydrothermal alteration at Bingham, Utah: Economic Geology, v. 73, no. 7, p. $1260-1269$. 
Moore, W.J., Curtin, G.C., Roberts, R.J., and Tooker, E.W., 1966, Distribution of selected metals in the Stockton district, Utah: U.S. Geological Survey Research 1966, Professional Paper 550-C, p. C197-C205.

Moore, W.J., Lanphere, M.A., and Obradovich, J.D., 1968, Chronology of intrusion, volcanism, and ore deposition at Bingham, Utah: Bulletin of Economic Geology, v. 63, no. 6, p. 612-621.297.

Moore, W.J., Hedge, C.E., and Sorensen, M.L., 1979, Variations in $87 \mathrm{Sr} / 86 \mathrm{Sr}$ ratios of igneous rocks along the Uinta trend, northwestern Utah: Geological Society of America Abstracts with Programs, v. 11, no. 6, p. 297.

Moore, W.J., and Lanphere, M.A., 1971, The age of porphyrytype copper mineralization in the Bingham mining district Utah--A refined estimate: Economic Geology, v. 66, no. 2, p. 331-334.

Moore, W.J., and McKee, E.H., 1983, Phanerozoic magmatism and mineralization in the Tooele 1 x 2 degree Quadrangle, Utah, in Miller, D.M., Todd, V.R., and Howard, K.A., eds., Tectonic and stratigraphic studies in the eastern Great Basin: Geological Society of America Memoir 157, p. 183-190.

Morris, H.T., 1983, Interrelations of thrust and transcurrent faults in the central Sevier orogenic belt near Leamington, Utah, in Miller, D.M., Todd, V.R., and Howard, K.A. eds., Tectonic and stratigraphic studies in the eastern Great Basin: Geological Society of America Memoir 157, p. 75-82.

Morris, H.T., Douglass, R.C., and Kopf, R.W., 1977, Stratigraphy and microfaunas of the Oquirrh Group in the southern East Tintic Mountains, Utah: U.S. Geological Survey Professional Paper 1025, 22 p.

Morris, H.T., and Lovering, T.S., 1961, Stratigraphy of the East Tintic Mountains, Utah: U.S. Geological Survey Professional Paper 361, 145 p.

Morris, H.T. and Tooker, E.W., 1996, Characterization and dating of argillic alteration in the Mercur gold district, Utah--A discussion: Economic Geology, v. 91, p.477-479.

Murphy, J.R., 1872, The mineral resources of the Territory of Utah, with mining statistics and maps: Salt Lake City, p. $1-40$.

Nelson, S.T., Harris, R.A., Dorais, M.J., Heizler, Matthew, Constenius, K.N, and Barnett, D.E., 2002, Basement complexes in the Wasatch fault, Utah, provide new limits on crustal accretion, Geology, v. 30, no. 9, p.831-834.

Nolan, T.B., 1943, The Basin and Range province in Utah, Nevada and California: U.S. Geological Survey Professional Paper 197-D, p. 141-196.
Nygreen P.W. 1958, The Oquirrh Formation--Stratigraphy of the lower portion in the type area and near Logan, Utah: Utah Geological and Mineralogical Survey Bulletin $61,67 \mathrm{p}$.

Oriel, S.S., and Armstrong, F.C., 1966, Times of thrusting in the Idaho-Wyoming thrust belt--Reply: Bulletin of the American Association of Petroleum Geologists, v. 50, no. 12, p. 2614-2621.

Ornelas, R.H., 1953, Clay deposits of Utah County, Utah: Provo, Utah, Brigham Young University, unpub., M.S. thesis.

Page, N. J, and Tooker, E.W., 1979, Preliminary map of platinum and platinum-group metal provinces in the conterminous United States: U.S. Geological Survey Open-File report 79-576B, scale 1:5,000,000.

Parry, W.T., Wilson, P.N., Jasumbach, Mark, and Heizler, M.T., 1997, Clay mineraloagy and Ar-Ar dating of phyllic and argillic alteration at Bingham, Utah, in John, D.A., and Ballantyne, G.H., eds., Geology and ore deposits of the Oquirrh and Wasatach Mountains: Guidebook of Society of Economic Geologists field trip, October 25, 1997, Guidebook Series No. 29, p. 245-274.

Peacock, H.G., 1948, An outline of the geology of the Bingham district: American Institute of Mining and Metallurgical Engineers, v. 29, no. 502, p. 533-534.

Peters, W.C., James, A.H., and Field, C.W., 1966, Geology of the Bingham Canyon porphyry copper ore body at Bingham, Utah, in Titley, S.R. and Hicks, C.L., eds., Geology of the porphyry copper deposits, southwestern North America: Tucson, Ariz., University of Arizona Press, p. 165-175.

Peterson, J.A., 1977, Paleozoic shelf-margins and marginal basins, western Rocky Mountains-Great Basin, United States, in Twenty-ninth annual field conference guidebook1977: Wyoming Geological Association, p. 135-153.

Peterson, O.P., 1924, Some geological features and court decisions of the Utah Apex-Utah Consolidated controversy, Bingham district: American Institutes of Mining and Metallurgical Engineers Transactions, v. 70, p. 904-932.

Presnell, R.D., 1992, Geology and geochemistry of the Barneys Canyon gold deposit, Salt Lake County, Utah: Salt Lake City, University of Utah, unpub. Ph.D. dissertation $363 \mathrm{p}$.

Presnell, R.D. and Parry, W.T., 1996, Geology and geochemistry of the Barneys Canyon gold deposit, Utah; Economic Geology, v. 91, p. 273-288.

Poole, F.G., 1974, Flysh deposits of the Antler foreland basin, western Untied States, in Dickinson, W.R., ed., Tectonics and sedimentation: Society of Economic Paleontologists and Mineralogist, Special Publication 22, p. 58-82 
Price, R.A., 1989, The mechanical paradox of large overthrusts: Bulletin of Geological Society of America, v. 100, no. 12 , p. $1889-1908$.

Reed, J.C., Ball, T.T., Farmer, G.L., and Hamilton, W.B., 1993, A broader view, in, Reed, J.C., Jr., ed., Precambrian--Conterminous U.S.: Geological Society of America, The geology of North America, v. C-2, p.597-636.

Rigby, J.K., ed., 1958, Geology of the Stansbury Mountains, eastern Tooele County, Utah: Utah Geological Society, Guidebook to the geology of Utah, no. 13, p. 1-134.

Rigby, J.K., 1959, Structural setting of the Mercur-Ophir areas, in Bissell, H.J., ed., Geology of the southern Oquirrh Mountains and Fivemile Pass--northern Boulter Mountain area, Tooele and Utah Counties, Utah: Utah Geological Society, Salt Lake City, Utah, Guidebook to the geology of Utah, no. 14, p. 227-229.

Roberts, R.J., 1964, Stratigraphy and structure of the Antler Peak Quadrangle, Humboldt and Lander Counties, Nevada: U.S. Geological Survey Professional Paper 459-A, 93 p.

Roberts, R.J. and Crittenden, M.D., Jr., 1973, Orogenic mechanism, Sevier orogenic belt, Nevada and Utah, in Dejong, K.A., and Sholten, Robert, eds., Gravity and tectonics: New York, John Wiley and Sons, p. 409-428.

Roberts, R.J. and Crittenden, M.D., Jr., Tooker, E.W., Morris, H.T., Hose, R.K., and Cheney, T.M., 1965, Pennsylvanian and Permian basins in northwestern Utah, northeastern Nevada, and south central Idaho: Bulletin of the American Association of Petroleum Geologists, v. 49, no. 11, p. 1926-1956.

Roberts, R.J., and Tooker, E.W., 1961, Structural geology of the north end of the Oquirrh Mountains, in Cook, D.R., ed., Geology of the Bingham mining district and northern Oquirrh Mountains: Utah Geological Society Guidebook, no. 16 , p. $36-48$.

Roberts, R.J., and Tooker, E.W., 1969, Age and regional significance of conglomerate in the Newfoundland and Silver Island Mountains Utah [abs.]: Geological Society of America Abstracts with Programs, pt. 5, p. 69.

Rubey, W.W., and Hubbert, M.K., 1959, Overthrust belt in geosynclinal area of western Wyoming in light of fluidpressure hypothesis [Pt. II of Role of fluid pressure in mechanics of overthrust faulting]: Geological Society of America Bulletin, v. 70, no. 2, p. 167-205.

Rubright, R.D., 1978, Geology of the Ophir district, Utah, in Shawe, D.R., and Rowley, P.D., eds., Guidebook to mineral deposits of southwestern Utah: Utah Geological Association, Salt Lake City, Utah, p. 14-19.

Rubright, R.D., and Hart, O.J., 1968, Non-porphyry ores of the Bingham district, Utah, in Ridge, J.D., ed., Ore deposits of the United States, 1933-1967 [Graton-Sales volume]: New York, American Institute of Mining and Metallurgical and Petroleum Engineers, v. 1, p. 886-907.
Sears. J.W., Graff. P.J., Holden, G.S., 1982, Tectonic evolution of lower Proterozoic rocks, Uinta Mountains, Utah and Colorado: Geological Society of America Bulletin, v. 93, no. 10, p. 990-997.

Shawe, D.R., and Stewart, J.H., 1976, Ore deposits as related to tectonics and magmatism, Nevada and Utah: Transactions of the Society of Mining Engineers of AIME, v. 260, no. 3, p. 225-232.

Singer, D.A., Berger, V.I. and Morey, D.C., 2002, Porphyry copper deposits of the world dat abse maps and preliminary analysis: U.S. Geological Survey, Open File Report 02-268, map 36.

Sinkankas, John, 1976, Variscite, in Gemstones of North America, Vol. 1: D. Van Nostrand Co., Inc., Princeton, New Jersey, p. 231-232.

Skillings, D.N., Jr., 1983, Getty Mining Co. starting up its Mercur gold operation in Utah: Skilling's Mining Review, v. 72, no. 1, p. 4-9.

Skillings, D.N., 1988, BP Minerals commences Barneys Canyon gold project in Utah: Skilling's Mining Review, v. 77, no. 46 , p. 17.

Slentz, L.W., 1955, Salt Lake Group in lower Jordan Valley, Utah, in Eardley, A.J., ed., Tertiary and Quaternary geology of the eastern Bonneville Basin: Utah Geological Society, Guidebook to the geology of Utah, v. 10, p. 23-36.

Smith, W.H., 1961, The volcanics of the eastern slopes of the Bingham district, in Cook, D.R., ed., Geology of the Bingham mining district and the northern Oquirrh Mountains: Utah Geological Society, Guidebook to the geology of Utah, no. 16, p. 101-119.

Spieker, E.M., 1946, Late Mesozoic and early Cenozoic history of central Utah: U.S. Geological Survey Professional Paper 205-D, p. D117-D161.

Spurr, J.E., 1895, Economic geology of the Mercur mining district: U.S. Geological Survey, 16th Annual Report, 189495 , pt. 2, p. 395-455.

Stacey, J.S., Moore, W.J., and Rubright, R.D., 1967, Precision measurement of lead isotope ratio--Preliminary analyses from the U.S. mine, Bingham Canyon, Utah: Earth and Planetary Science Letter, v. 2, p. 489-499.

Stacey, J.S., Zartman, R.E., and Nkomo, I.T., 1968, A lead and strontium isotope study of galenas and selected feldspars from mining districts in Utah: Economic Geology, v. 63, no. 7, p. 796-814.

Standard Oil Company, 1986, 1986 financial and operating information: Cleveland, Ohio, Standard Oil Company, p. 40.

Steele, Grant, 1960, Pennsylvanian-Permian stratigraphy of east central Nevada and adjacent Utah, in Geology of east central Nevada: Intermountain Association of Petroleum Geologists, 11tth Annual Field Conference, 1980, Guidebook, p. 91-113. 
Stein, H.J., Bankey, Viki, Cunningham, C.G., Zimbelman, D.R., Brickey, D.W., Shubat, M.A., Campbell, D.L., and Podwsocki, M.H., 1989, The Tooele 1x2 degree quadrangle, northwest Utah--an example of a CUSMAP preassessment study: U.S. Geological Survey Open-File report OF 89-467, 134 p. [see also in Schindler, K.S., ed., Fifth annual V.E. McKelvey Forum program and abstracts: U.S. Geological Survey Circular 1035, p. 70-71].

Stewart, J.H., 1978, Basin and range structure in western North America--A review, in Smith, R.B., and Eaton, G.P., eds., Cenozoic tectonics and regional geophysics of the western Cordillera: Geological Society of America Memoir 152, p. 1-31.

Stewart, J.H., and Poole, F.G., 1974, Lower Paleozoic and uppermost Precambrian Cordilleran miogeocline, Great Basin, western United States, in Dickinson, W.R., ed., Tectonics and sedimentation: Society of Economic Paleontologists and Mineralogists Special Publication, no. 22, p. 28-57.

Stewart, J.H., Moore, W.J., and Zietz, Isidore, 1977, East-west patterns of igneous rocks, aeromagnetic anomalies, and mineral deposits, Nevada and Utah: Geological Society of America Bulletin, v. 88, no. 1, p. 67-77.

Stolp, B.J., 1994, Hydrology and potential for ground-water development in southeastern Tooele Valley and adjacent areas in the Oquirrh Mountains, Tooele County, Utah: Utah State Department of Natural Resources, Technical Pub. No. 107, $67 \mathrm{p}$.

Stowe, C.H., 1975, Utah mineral industry statistics through 1973: Utah Geological and Mineral Survey, Bulletin 106, $121 \mathrm{p}$.

Swensen, A.J., 1975a, Sedimentary and igneous rocks of the Bingham district [Utah], in Bray, R.E., and Wilson, J.C., eds., Guidebook to the Bingham mining district: Society of Economic Geologists, p. 21-39.

Swensen, A.J., compiler, 1975b, Geologic map of the Bingham district, in Bray, R.E., and Wilson, J.C., eds., Guidebook to the Bingham mining district, Society of Economic Geologists, October 23, 1975: Bingham Canyon, Utah, Kennecott Copper Corporation, pl. 1, scale 1:24,000.

Tafuri, W.J., 1987, Geology and geochemistry of the Mercur mining district, Tooele County, Utah: Salt Lake City,Utah, University of Utah, unpub. Ph.D. dissertation, 180 p.

Taylor, J.R., 1991, Mesozoic structure of the Stansbury Mountains, Tooele County, Utah: Geologic Society of America, Abstract with Programs 1991, p. 102.

Todd, V.R., 1983, Late Miocene displacement of Pre-Tertiary and Tertiary rocks in the Matlin Mountains, northwestern Utah, in Miller, D.M., Todd, V.R., Howard, K.A., eds., Tectonic and stratigraphic studies in the eastern Great Basin: Geological Society of America Memoir 157, p. 239-270.
Tooker, E.W., 1970, Radial movements in the western Wyoming salient of the Cordilleran overthrust belt-Discussion: Geological Society of America Bulletin, v. 81, no. 11, p. 3503-3506.

Tooker, E.W., 1971, Regional structural controls of ore deposits, Bingham mining district, Utah, U.S.A., in International Association of the Genesis of Ore Deposits, Tokyo-Kyoto: Tokyo, Japan, Meetings, papers, and proceedings, Geological Society of Minerals, Japan, Special Issue No. 3, p. 76-81.

Tooker, E.W., 1979, Metal provinces and plate tectonics in the conterminous United States, in Ridge, J.D., ed., Papers on mineral deposits of western North America: Nevada Bureau of Mines and Geology Report 33, p. 33-38,

Tooker, E.W., 1980, Preliminary geologic map of the Tooele Quadrangle, Tooele County, Utah: U.S. Geological Survey Open-File Report 80-623, scale 1;24,000.

Tooker, E.W., 1983, Variations in structural style and correlation of thrust plates in the Sevier foreland thrust belt, Great Salt Lake area, Utah, in Miller, D.M., Todd, V.R., and Howard, K.A., eds., Tectonic and stratigraphic studies in the eastern Great Basin: Geological Society of America Memoir 157, p. 61-73.

Tooker, E.W., 1987, Preliminary geologic maps, cross sections, and explanation pamphlet for the Ophir and Mercur quadrangles, Utah: U.S. Geological Survey Open-File Report 87-152, scale 1:24,000.

Tooker, E.W., 1990, Gold in the Bingham district, Utah, in Shawe, D.R., ed., Geology of gold in the United States, gold in porphyry copper systems: U.S. Geological Survey Bulletin 1857-E, p. E1-E16.

Tooker, E.W., compiler, 1992, Preliminary geologic map of the Lowe Peak 7 1/2-minute quadrangle, Tooele, Utah, and Salt Lake Counties, Utah: U.S. Geological Survey Open-File Report 92-404, 13 p., scale 1:24,00.

Tooker, E.W., 1998, Sevier-age thrust fault structures control the location of base- and precious-metal mining district in the Oquirrh Mountains, Utah: U.S. Geological Survey Open-File Report 98-234, 66 p.

Tooker, E.W., 1999, Geology of the Oquirrh Mountains, Utah: U.S. Geological Survey Open-File Report 99-571, 150 p.

Tooker, E.W., and Roberts, R.J., 1962, Comparison of Oquirrh Formation sections in the northern and central Oquirrh Mountains, in U.S. Geological Survey Research 1962: U.S. Geological Survey Professional Paper 450E, p. E32-E36.

Tooker, E.W., and Roberts, R.J., 1970, Upper Paleozoic rocks in the Oquirrh Mountains and Bingham mining district, Utah, with a section on Biostratigraphy and correlation by Gordon, Mackenzie, Jr., and Duncan, H.M.: U.S. Geological Survey Professional Paper 629-A, 76 p. 
Tooker, E.W., and Roberts, R.J., 1971a, Geology of the Mills Junction Quadrangle, Utah: U.S. Geological Survey Quadrangle Map, GQ-924, scale 1:24,000.

Tooker, E.W., and Roberts, R.J., 1971b, Geology of the Garfield Quadrangle, Utah: U.S. Geological Survey Quadrangle Map, GQ-922, scale 1:24,000.

Tooker, E.W., and Roberts, R.J., 1971c, Geology of the Magna Quadrangle, Utah: U.S. Geological Survey Geologic Quadrangle Map, GQ-923, scale 1:24,000.

Tooker, E.W., and Roberts, R.J., 1988, Preliminary geologic map, cross-sections, and explanation pamphlet for the Bingham Canyon Quadrangle, Salt Lake and Tooele Counties, Utah: U.S. Geological Survey Open-File Report 88-699, scale 1:24,000.

Tooker, E.W., and Roberts, R.J., 1992. Preliminary geologic map of the Stockton 7 1/2-minute quadrangle, Tooele County, Utah: U.S. Geological Survey Open-File Report 92-385, 22 p., scale 1:24,000.

Tooker, E.W., and Roberts, R.J., 1998, Geologic map of the Oquirrh Mountains and adjoining South and West Traverse Mountains, Tooele, Utah, and Salt Lake Counties, Utah: U.S. Geological Survey Open-File Map 98-581, scale $1: 50,000$.

Tripp, B.T., 1992, Assessment of present and future production of industrial minerals in the Basin and Range regionsindustrial rock and mineral production in Utah, 1990, in Tooker, E.W., compiler-editor, Industrial minerals in the Basin and Range region-workshop proceedings: U.S. Geological Survey Bulletin 2013, p. 11-22.

Tripp, B.T., Shubat, M.A., Bishop, C.E., and Blackett, R.E., 1989, Mineral occurrences of the Tooele 1x2 degree quadrangle, west central Utah: Utah Geological and Mineral Survey, Open-File Report 89-153, 85 p.

U.S. Bureau of Mines 1924-1993, Mineral resources of the United States [annual volumes for the years indicated].

U.S. Bureau of Mines, 1955, Mineral property file 87-43.

U.S. Bureau of Mines, 1961-1981, Gold, in U.S. Bureau of Mines Minerals Yearbooks: U.S. Bureau of Mines [annual volumes for the year indicated].

U.S. Geological Survey 1883-1923, Mineral resources of the United States [annual volumes for the years indicated].

Vogel, T.A., Cambray, F.W., and Constenius, K.N., 2002, Origin and emplacement of the igneous rocks from the central Wasatch Mountains, Utah, Rocky Mountain Geology, v. 36, p.119-162
VonTish, D.B., Allmendinger, R.W., and Sharp, J.W., 1985, History of Cenozoic extension of central Sevier Desert, west-central Utah, from COCORP seismic reflection data: American Association of Petroleum Geologists Bulletin, v. 69, no. 7, p. 1077-1087.

Waite, K.A., Keith, J.D., Christiansen, E.H., Tingey, D.G., Whitney, J.A., Hook, C.J., and Hattori, Keiko, 1997, Petrogenesis of the volcanic and intrusive rocks associated with the Bingham Canyon porphyry $\mathrm{Cu}-\mathrm{Au}-\mathrm{Mo}$ deposti, Utah, in Johns, D.A., and Ballantyne, G.H., Geology and ore deposits of the Oquirrh and Wasatch Mountains, Utah: Guidebook for the Society of Economic Geologists field trip, Oct. 1997, p. 91-128.

Warnaars, F.W., Smith, W.H., Bray, R.E., Lanier, George, and Shafiqullah, Muhammed, 1978, Geochronology of igneous intrusions and porphyry copper mineralization at Bingham, Utah: Economic Geology, v. 73, no. 7, p. 1242-1249.

Webb, G.W., 1958, Middle Ordovician stratigraphy in eastern Nevada and western Utah: American Association of Petroleum Geologists Bulletin, v. 42, no. 10, p. 2335-2377.

Wegg, D.S., Jr., 1915, Bingham mining district, Utah: Salt Lake City, University of Utah, unpub. M.S. thesis.

Welch, J.E. and James, A.H., 1961, Pennsylvanian and Permian stratigraphy of the central Oquirrh Mountains, Utah, in Cook, D.R., ed., Geology of the Bingham mining district and northern Oquirrh Mountains: Salt Lake City, Utah, Utah Geological Society, Guidebook to the geology of Utah, no. 16 , p. 1-16.

Wenicke, B., 1981, Low-angle normal faults in the Basin and Range Province--nappe tectonics in and extending orogen: Nature, v. 291, p.645-648.

Wicks, F.D., 1987, The Barrick Mercur gold mine: Mining Magazine, v. 151, no. 5, p. 398-405.

Wilson, J.C., 1978, Ore fluid-magma relationships in a vesicular quartz latite porphyry dike at Bingham, Utah: Economic Geology, v. 73, no. 7, p. 1287-1307.

Wilson, P.N., 1986, Thermal and chemical evolution of hydrothermal fluids at the Ophir Hill mine, Ophir district, Tooele County, Utah: Salt Lake City, University of Utah, unpub. M.S. thesis, $155 \mathrm{p}$.

Wilson, B.R., and Laule, S.W., 1979, Tectonics and sedimentation along the Antler orogenic belt in central Nevada, in Newman, G.W. and Goode, H.D., eds., Basin and Range symposium and Great Basin field conference: Salt Lake City, Utah, Rocky Mountain Association of Geologists and Utah Geological Association, p. 81-92.

Wilson, P.N., and Parry, W.T., 1994, Illite K/AR dates from the Mercur gold mine, Utah-Mixed ages indicate Mesozoic gold deposition [abstr.]: Abstracts with Program-Geological Society of America, in Geological Society of America 1994 Annual meeting, v. 26, no. 7, p. 142. 
Wilson, P.N., and Parry, W.T., 1995, Characterization and dating of argillic alteration in the Mercur gold district, Utah: Economic Geology, v. 90, n. 5, p. 1197-1216.

Wilson, P.N., and Parry, W.T., 1996, Characterization and dating of argillic alteration in the Mercur gold district, Utah--A reply: Economic Geology, v. 91, p. 479-481.
Zietz, Isadore, Shuey, Ralph, and Kirby, Jr., 1976, Aeromagnetic map of Utah: U.S. Geological Survey Geophysical Investigations Map, GP-907, scale 1:1,000,000.

Zobach, M.L., 1983, Structure and Cenozoic tectonism along the Wasatch fault zone, Utah: Geological Society of America Memoir 157, p. 3-27. 


\section{Appendix 1. Columnar section of the Permian-age Curry, Clinker, and Kirkman formational units of Welsh and James (1961, plate 5), from Section No. 2 [Bingham] District Geology Map.}

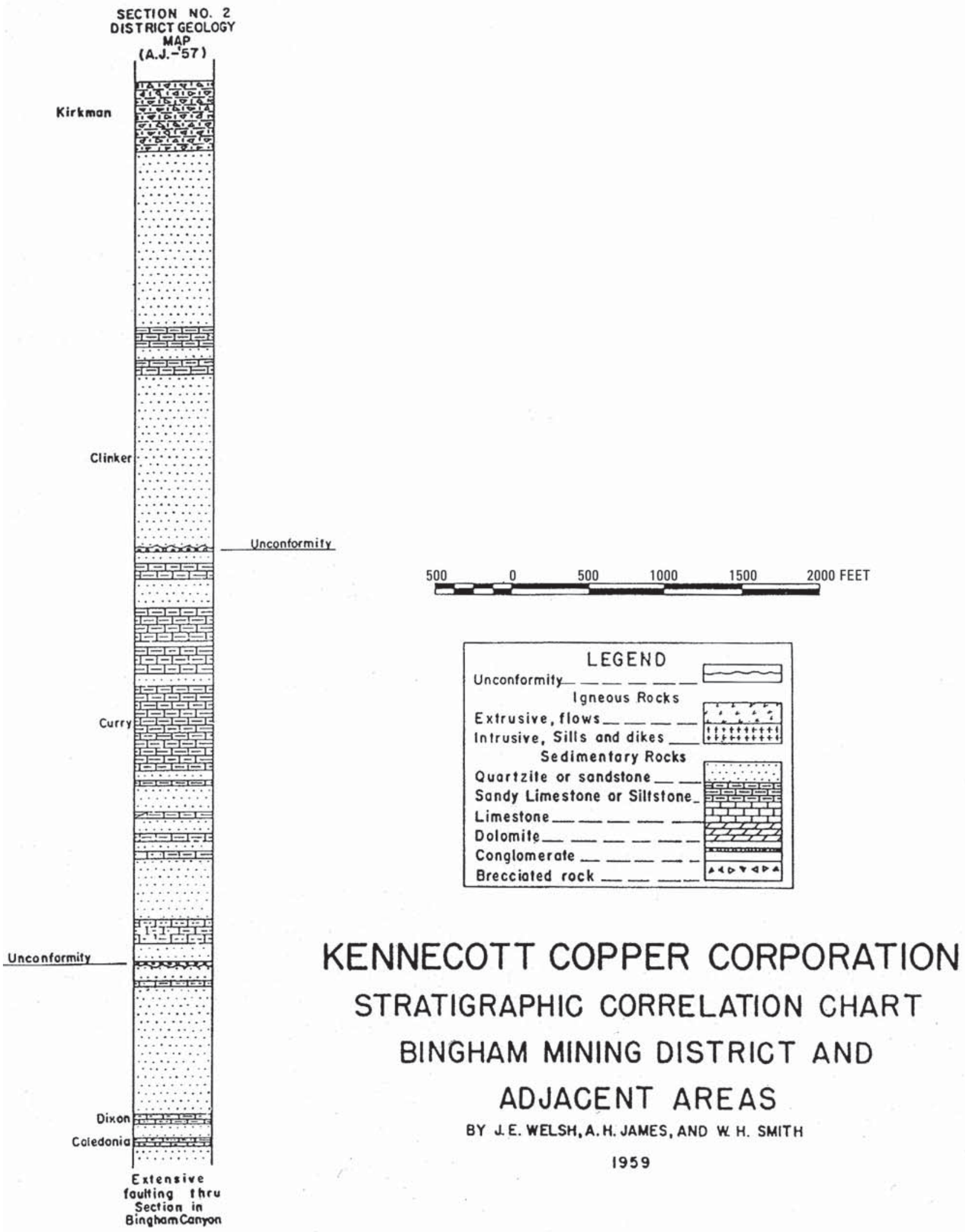




\section{Appendix 2. Measured sections of the $(A)$ South Peak, $(B)$ Salvation, and $(C)$ Rush Lake formational units of Tooker and Roberts (1992) that constitute the Oquirrh Group sedimentary rocks in the South Mountain Nappe.}

A, Stratigraphic section of the South Peak unit of Tooker and Roberts (1992) composed of the upper part of the Oquirrh Group (Early Permian) measured on South Mountain along the ridge across SE-1/4 sec. 13, R. 6 W., T.4 S. and S-1/2 sec. 18, SW-1/4 sec. 17, R. 5 W., T. 4 S., South Mountain 7 1/2-min. quadrangle, Utah. [Measured by R.J. Roberts and E.W. Tooker, October 1961]

\begin{tabular}{|c|c|c|}
\hline & $\begin{array}{l}\text { Thickness } \\
\text { (meters) }\end{array}$ & $\begin{array}{l}\text { Distance above base } \\
\text { (meters) }\end{array}$ \\
\hline $\begin{array}{l}\text { Covered by alluvium and overlapped by the concealed north-trending Tintic Valley } \\
\text { thrust fault } \\
\text { Unconformity } \\
\text { Stratigraphic section of the South Peak unit of Tooker and Roberts (1992) }\end{array}$ & & 1,904 \\
\hline $\begin{array}{l}\text { 22. Calcareous quartzite, light buff-tan, fine sand, medium-bedded to massive, well- } \\
\text { jointed and fractured, interbedded orthoquartzite, bioclastic limestone and sand } \\
\text { partings with fusulinids; weathers red-brown to tan, thin surface rind, in part platy } \\
\text { float; mostly covered slope. USGS colln. f22621 near top, "Bioclastic limestone } \\
\text { with well rounded sand grains, bryozoa, Triticites sp. and Schwagerina sp., some } \\
\text { incipient euniculi. The age suggested is early Permian, late Wolfcamp to earliest } \\
\text { Leonard equivalent" (R.C. Douglass, written commun. 1962). }\end{array}$ & 243 & 1,661 \\
\hline $\begin{array}{l}\text { 21. Calcareous quartzite, orthoquartzite and limestone interbedded, medium light-gray, } \\
\text { coarse-grained to sandy, calcareous cement, medium-bedded orthoquartzite and } \\
\text { sand partings, banded; weathers light-gray, grains in relief; finer dark gray limy } \\
\text { clastic sands include fossil fragments (brachiopods), calcareous mudstone at } 11 \mathrm{~m} \text {, } \\
\text { and fusulinids in sandy limestone with phosphate coating; mostly covered slope. } \\
\text { USGS colln. f22620 at } 16 \mathrm{~m} \text {, "Well-rounded sandstone with detrital fragments of } \\
\text { bryozoa, Triticites sp. and Schwagerina sp. The age suggested is Early Permian, } \\
\text { late Wolfcamp equivalent" (R.C Douglass, written commun, 1962). }\end{array}$ & 47 & 1,614 \\
\hline $\begin{array}{l}\text { 20. Calcareous quartzite, tan-to-olive gray, sandy, mostly calcareous cement, medium- } \\
\text { bedded to massive, thin-bedded sandstone layers with worm trails; weathers red- } \\
\text { brown to buff with thick surface rind; mostly covered slope }\end{array}$ & 265 & 1,349 \\
\hline $\begin{array}{l}\text { 19. Sandstone and calcareous quartzite, interbedded; buff, sandy; weathers deep yellow- } \\
\text { brown; contains worm trails and fusulinid molds; mostly covered slope. }\end{array}$ & 119 & 1,230 \\
\hline $\begin{array}{l}\text { 18. Calcareous quartzite and orthoquartzite, interbedded, tan-buff, to olive-gray and } \\
\text { light-gray, sandy, medium bedded; interbedded ferruginous sandstone 0.9-1.8 m } \\
\text { thick contains worm trails; weathers light brown-tan; covered slope. }\end{array}$ & 52 & 1,178 \\
\hline $\begin{array}{l}\text { 17. Orthoquartzite, and calcareous quartzite, interbedded, tan-buff and light brown } \\
\text { bands, sandy; interbedded ferruginous sandstone; weathers yellow-tan and reddish } \\
\text { brown, ferruginous surface rind on calcareous quartzite, worm trails; covered slope. }\end{array}$ & 8 & 1,170 \\
\hline Porphyry dike & 11 & \\
\hline $\begin{array}{l}\text { 16. Calcareous quartzite and orthoquartzite interbedded, tan-buff to light-gray, medium } \\
\text { grained to sandy, medium-bedded, local banding; interbedded limy sandstone layers; } \\
\text { weathers light brown-tan, very thin surface rind; covered slope. }\end{array}$ & 5 & 1,165 \\
\hline $\begin{array}{l}\text { 15. Calcareous quartzite, orthoquartzite, interbedded; quartzite contains molds of } \\
\text { fusulinids, near top; bedded chert with preserved fusulinids; chert pebbles of earlier } \\
\text { rocks; phosphatic replacement of fusulinids; mostly covered slope. USGS colln. } \\
\text { f22619 at } 12.9 \text { m, "Coarse sand with Schwagerina sp. as detrital fragments, abraded } \\
\text { and chemically altered. The age suggested is Early Permian, Wolfcamp equivalent" } \\
\text { (R.C. Douglass written commun. 1962). }\end{array}$ & 13 & 1,152 \\
\hline
\end{tabular}




\begin{tabular}{|c|c|c|}
\hline Stratigraphic section of the South Peak unit—Continued. & $\begin{array}{l}\text { Thickness } \\
\text { (meters) }\end{array}$ & $\begin{array}{l}\text { Distance above base } \\
\text { (meters) }\end{array}$ \\
\hline $\begin{array}{l}\text { 14. Calcareous quartzite, tan-buff to olive-gray, fine to coarse grained in upper part, } \\
\text { medium-bedded, often thin inter-bedded orthoquartzite and limy sandstone beds; } \\
\text { weathers reddish-brown to light-buff-gray, with soft surface rind } 8 \mathrm{~cm} \text { thick; poorly } \\
\text { preserved fusulinid molds at top; mostly covered slope. }\end{array}$ & 158 & 994 \\
\hline $\begin{array}{l}\text { 13. Ferruginous sandstone, yellow-brown, sandy, medium to thin bedded with thin in- } \\
\text { terbedded calcareous quartrzite and bedded chert; weathers medium brown, rounded } \\
\text { float; covered slope. }\end{array}$ & 53 & 941 \\
\hline $\begin{array}{l}\text { 12. Calcareous quartzite, medium-gray, sandy, thin to medium bedded, interbedded } \\
\text { sandy limestone and platy limy sandstone, largely ferruginous beds up to } 1 \mathrm{~m} \text { in } \\
\text { upper part, local banded thin phosphatic chert beds; weather reddish-brown and yel- } \\
\text { low-brown, rounded fragments with medium soft surface rind; worm trails common } \\
\text { in ferruginous sandstone; mostly covered slope. }\end{array}$ & 114 & 827 \\
\hline Porphyry dike & 51 & \\
\hline $\begin{array}{l}\text { 11. Calcareous quartzite, medium-gray, medium-grained, thin- to medium-bedded, } \\
\text { locally banded, interbedded thin, sandy limestone containing worm trails and limy } \\
\text { sandstone partings; weathers reddish-brown and light-tan, sandy surface, thin sur- } \\
\text { face rind, platy fragments in part; mostly covered slope. }\end{array}$ & 18 & 809 \\
\hline $\begin{array}{l}\text { 10. Calcareous quartzite and sandstone, interbedded; orthoquartzite and platy limy } \\
\text { sandstone with worm trails, and bedded chert; covered slope. }\end{array}$ & 132 & 677 \\
\hline $\begin{array}{l}\text { 9. Limestone, dark gray, sandy, thin-bedded sandstone partings; weathers medium dark } \\
\text { gray, sand partings, weathers brown-tan, covered slope. }\end{array}$ & 0.6 & 676 \\
\hline $\begin{array}{l}\text { 8. Orthoquartzite, light gray-tan to olive gray medium grained to sandy, mostly me- } \\
\text { dium-bedded with interbedded calcareous quartzite, ferruginous sandstone, bedded } \\
\text { chert, and platy limy sandstone; weathers brown-tan; fusulinid molds locally, worm } \\
\text { trails in sandstone; covered slope. }\end{array}$ & 114 & 562 \\
\hline $\begin{array}{l}\text { 7. Limestone, medium dark-gray, dense, fine-grained to silty, sandstone partings; } \\
\text { weathers medium light-gray; covered slope. }\end{array}$ & 0.7 & 561 \\
\hline $\begin{array}{l}\text { 6. Calcareous quartzite and ferruginous sandstone, interbedded, light gray-tan medium } \\
\text { grained to sandy; worm trails and fususlinid molds in sandstone and quartzite; } \\
\text { weathers brown-tan; covered slope. }\end{array}$ & 41 & 521 \\
\hline $\begin{array}{l}\text { 5. Limestone, medium dark-gray, fine grained to sandy, with sand partings and lenses; } \\
\text { weathers medium-gray; covered slope }\end{array}$ & 0.6 & 520 \\
\hline $\begin{array}{l}\text { 4. Calcareous quartzite and orthoquartzite, interbedded; light gray-tan, medium grained } \\
\text { to sandy, occasional yuellow-brown thin-bedded partings and thin to medium beds } \\
\text { of ferruginous sandstone that weather reddish-brown-tan, thick surface rinds on } \\
\text { rounded float from calcareous quartzite, orthoquartzite has more angular float; } \\
\text { fusulinid molds found in sandstone at } 104 \mathrm{~m} \text {, worm trails occur in some of the fer- } \\
\text { ruginous sandstone; mostly covered slope. }\end{array}$ & 357 & 163 \\
\hline $\begin{array}{l}\text { 3. Ferruginous sandstone and calcareous quartzite, interbedded; sandstone brown, me- } \\
\text { dium grained to sandy, ferruginous cement; weathers dark reddish-brown; worm trails, } \\
\text { and fusulinid molds occur locally; quartzite thin-bedded, banded; covered slope. }\end{array}$ & 38 & 125 \\
\hline $\begin{array}{l}\text { 2. Orthoquartzite, tan, sandy, silica cement, medium bedded, banded and crossbedded } \\
\text { locally; weathers reddish-brown; covered slope. }\end{array}$ & 4 & 121 \\
\hline $\begin{array}{l}\text { 1. Limestone and calcareous quartzite, interbedded; sandy limestone with interbedded } \\
\text { ferruginous sandstone locally; covered slope. }\end{array}$ & 121 & \\
\hline Total South Peak unit measured & 1,903 & \\
\hline Conformable contact & & \\
\hline $\begin{array}{l}\text { Salvation unit, Oquirrh Group (upper beds only) } \\
\text { 17. Limestone, medium-gray, fossiliferous. }\end{array}$ & & \\
\hline
\end{tabular}


$B$, Stratigraphic section of the Salvation unit of Tooker and Roberts (1992) in the Oquirrh Group on the South Mountain nappe, measured on South Mountain along the ridge across S-1/2 sec. 22 and N-1/2 sec. 21, T. 4 S., R. 5 W., Stockton 15-min. or South Mountain 7-1/2 min. quadrangles. [Measured by R.J. Roberts and E.W. Tooker, October, 1961]

\begin{tabular}{|c|c|c|}
\hline & $\begin{array}{l}\text { Thickness } \\
\text { (meters) }\end{array}$ & $\begin{array}{c}\text { Distance above base } \\
\text { (meters) }\end{array}$ \\
\hline $\begin{array}{l}\text { South unit, Oquirrh Group (lowest beds only): } \\
\text { Limestone and quartzite, interbedded; sandy limestone and calcareous quartzite with } \\
\text { local interlaminated ferruginous sandstone; covered slope. } \\
\text { Contact conformable. } \\
\text { Salvation unit, Oquirrh Group: }\end{array}$ & & 832 \\
\hline $\begin{array}{l}\text { 17. Limestone, medium-gray, fine-grained to sandy, medium-bedded; weathers medium } \\
\text { light gray; productid brachiopods, fusulinids in sandy limestone. } \\
\text { USGS colln. f22623 at } 14 \text { m, "Fine sand with Triticites sp. The age suggested is } \\
\text { Late Pennsylvanian, probably late Missouri or earliest Virgil equivalent." (R.C. Dou- } \\
\text { glass, written commun. 7/20/62). A brachiopod was identified as "Linoproductus } \\
\text { sp. indet." (Mackenzie Gordon,Jr., written commun. 10/14/66). } \\
\text { USGS colln. f22624 at } 24 \text { m, "Fine sand with Triticites sp. It probably is referable } \\
\text { to latest Missouri equivalent but an early Virgil age is a possibility." (R.C Doug- } \\
\text { lass, written commun. 7/20/62). Productid brachiopods and bryozoans common in } \\
\text { other layers. }\end{array}$ & 29 & 803 \\
\hline $\begin{array}{l}\text { 16. Quartzite and limestone, interbedded; light tan-gray, sandy, calcareous cement, } \\
\text { medium-bedded quartzite, and medium-gray, fine grained to sandy, medium-bedded } \\
\text { limestone with shale partings; weathers buff (quartzite) and light blue gray (lime- } \\
\text { stone); fossils locally in limestone include bryozoans and fusulinids. } \\
\text { USGS colln. f22622" at } 10 \mathrm{~m} \text {, "Fine sand with some bryozoa and Kansanella sp. } \\
\text { The age suggested is Late Pennsylvanian, probably Missouri equivalent." (R.C. } \\
\text { Douglass, written commun. 7/20/62). }\end{array}$ & 12 & 791 \\
\hline $\begin{array}{l}\text { 15. Quartzite, light-gray, sandy, mostly calcareous cement in lower part, silica cement } \\
\text { more common in upper part, medium-bedded, local banding, interbedded silica- } \\
\text { cemented quartzite in lower part and sandy limestone throughout, sparse ripple } \\
\text { marked surfaces noted locally; weathers red brown to tan; covered slope. }\end{array}$ & 69 & 722 \\
\hline $\begin{array}{l}\text { 14. Quartzite, light tan-gray, sandy, mostly calcareous cement, interbedded with locally } \\
\text { crossbedded, and often fossiliferous, medium dark-gray sandy limestone up to } 1 \mathrm{~m} \\
\text { thick; quartzite weathers buff, limestone medium blue-gray; fossils (identified by } \\
\text { R.C. Douglass, written commun., 7/20/62) in sandy limestone layers include fusuli- } \\
\text { nids, brachiopods, crinoids, bryozoans, Syringopora and cup corals. } \\
\text { USGS colln. } 22615 \text { at } 5 \text { m, "Fine sand with crinoidal debris, bryozoan fragments } \\
\text { and fragments of Kansanellaa sp. The age suggested is Late Pennsylvanian prob- } \\
\text { ably Missourii equivalent." } \\
\text { USGS colln. f22616 at } 46 \mathrm{~m} \text {, "Fine sand with Triticites sp. scattered, and bioclastic } \\
\text { limestone with Tetrataxis sp, texturalid, Bradyina sp., Millerella sp., and Fusulinella } \\
\text { sp. or Pseudofusulinella sp. This second piece really look like a piece from the } \\
\text { middle Pennsylvanian." } \\
\text { USGS colln. f22617 at } 147 \text { m, "Silty fragmented limestone with Bradyina sp. and } \\
\text { Kansanella sp. The age suggested is Late Pennsylvanian, probably Missouri equiva- } \\
\text { lent." } \\
\text { USGS colln. f22618 at } 126-132 \text { m, "Fine sand with abundant small fusulinids some- } \\
\text { thing like the kind Thompson calls Oketaella but more globular." and brachiopods } \\
\text { and corals in the uppermost part; mostly covered slope. }\end{array}$ & 203 & 519 \\
\hline $\begin{array}{l}\text { 13. Limestone, medium-gray, fine-grained to sandy, thick bedded; weathers olive brown } \\
\text { to light gray; corals, Derbyia brachiopods, bryozoans, and fusulinids. } \\
\text { USGS colln. f22614 at } 155 \mathrm{~m} \text {, "Fine sand with textularids and Triticites sp. The age } \\
\text { suggests Late Pennsylvanian, probably Missouri equivalent." R.C. Douglass, writ- } \\
\text { ten commun. 7/20/62. }\end{array}$ & 4 & 515 \\
\hline
\end{tabular}




\begin{tabular}{|c|c|c|}
\hline Salvation unit, Oquirrh Group-Continued: & $\begin{array}{l}\text { Thickness } \\
\text { (meters) }\end{array}$ & $\begin{array}{l}\text { Distance above base } \\
\text { (meters) }\end{array}$ \\
\hline $\begin{array}{l}\text { 12. Quartzite, light tan-gray, sandy, mostly calcareous cemented, medium-bedded with } \\
\text { interbedded limy sandstone, crossbedded in part, thin platy to shaly limestone part- } \\
\text { ings; weathers reddish brown to buff, medium-soft surface rind; covered slope. }\end{array}$ & 116 & 399 \\
\hline $\begin{array}{l}\text { 11. Quartzite, light tan-gray, sandy, mostly silica-cemented, massive to medium-bedded } \\
\text { with interbedded sandy limestone up to } .3 \mathrm{~m} \text { thick and thin interlayers of calcare- } \\
\text { ous-cemented quartzite, crossbedded locally; weathers tan buff, platy float; partly } \\
\text { covered slope. }\end{array}$ & 41 & 358 \\
\hline $\begin{array}{l}\text { 10. Limestone, medium-gray, fine-grained, thin-bedded; weathers light gray; mostly } \\
\text { covered slope. }\end{array}$ & 1 & 357 \\
\hline $\begin{array}{l}\text { 9. Quartzite, medium tan-gray, medium- to coarse-sandy, mostly calcareous cement, } \\
\text { medium-bedded to massive, interbedded thin laminae of limestone, limy sand- } \\
\text { stone, and shale partings, well-jointed, banded locally; weathers tan buff, pitted } \\
\text { thin surface rind, alternate hard and softer layers locally weather in relief; fossils in } \\
\text { interbedded sandy limestone, cup and Syringopora corals, brachiopods, gastropods, } \\
\text { crinoid stems, bryozoans. } \\
\text { USGS colln. } 61 \text { F76 at } 247 \mathrm{~m} \text {, "Syringoporoid coral, Straparollus (Euomphalus) sp. } \\
\text { ident." (Mackenzie Gordon, Jr., written commun. 10/4/66). }\end{array}$ & 271 & 86 \\
\hline $\begin{array}{l}\text { 8. Limestone, medium dark gray, fine grained to sandy, medium bedded; weathers light } \\
\text { gray with brown sand partings; platy float. }\end{array}$ & 3 & 83 \\
\hline $\begin{array}{l}\text { 7. Quartzite, medium dark-gray, sandy, calcareous cement, medium-bedded, banded } \\
\text { locally; weathers medium light gray with light-brown bands; mostly covered slope. }\end{array}$ & 8 & 75 \\
\hline $\begin{array}{l}\text { 6. Limestone, medium-gray, fine grained to sandy—-size increases upward-medium- } \\
\text { bedded, sand partings more abundant in upper part; weathers tan to medium light } \\
\text { gray, sandy surface, platy float; well-preserved fusulinids, cup corals abundant at } \\
\text { base. }\end{array}$ & 4 & 67 \\
\hline $\begin{array}{l}\text { 5. Quartzite and limestone, interbedded; (quartzite) calcareous cement (limestone) } \\
\text { sandy; covered slope. }\end{array}$ & 6 & 61 \\
\hline $\begin{array}{l}\text { 4. Limestone, medium-gray, fine-grained to sandy, medium-bedded; weathers light } \\
\text { blue gray, sandy surface; abundant fusulinid, brachiopod, bryozoan, crinoid assem- } \\
\text { blage. } \\
\text { USGS colln. f226ll at base, "Coarse bioclastic limestone with fragments of foramin- } \\
\text { ifera including Bradyina sp., and Pseudofusulinella sp." } \\
\text { USGS colln. f22612 at } 1 \mathrm{~m} \text {, "Fine sand with fragments of Triticites sp. The age } \\
\text { suggested is Late Pennsylvanian, Missouri equivalent." (R.C. Douglass, written } \\
\text { commun. 7/20/62. }\end{array}$ & 2 & 59 \\
\hline $\begin{array}{l}\text { 3. Quartzite and limestone, interbedded; light gray-tan to olive brown, sandy, calcare- } \\
\text { ous cemented, medium-bedded, locally banded and crossbedded quartzite, and me- } \\
\text { dium-gray platy limestone; weathers yellow brown to reddish brown, thick surface } \\
\text { rind (quartzite) and light gray (limestone); mostly covered slope. }\end{array}$ & 5 & 4 \\
\hline $\begin{array}{l}\text { 2. Limestone, medium-gray, sandy, medium-bedded; weathers light tan gray; abundant } \\
\text { crinoids, cup and Syringopora corals and fusulinid fauna. } \\
\text { USGS colln. f22610 at } 2 \mathrm{~m} \text {, "Fine sand with scattered fragments of Triticites sp. } \\
\text { The age suggested is Late Pennsylvanian Missouri equivalent." (R.C. Douglass, } \\
\text { written commun. 7/20/62). }\end{array}$ & 3 & 1 \\
\hline $\begin{array}{l}\text { 1. Limestone, medium dark-gray, fine-grained thin-bedded, locally laminated; weathers } \\
\text { blue gray, sandy surface; top } 0.3 \text { m brecciated and cemented with white calcite. }\end{array}$ & 1 & \\
\hline Total Salvation unit measured & 832 & \\
\hline Conformable contact. & & \\
\hline $\begin{array}{l}\text { Rush Lake unit, Oquirrh Group (upper beds only) } \\
\text { 37. Quartzite, light gray-tan, thin bedded, locally laminated. }\end{array}$ & & \\
\hline
\end{tabular}


C, Stratigraphic section of the Rush Lake unit of Tooker and Roberts (1992) in the Oquirrh Group, South Mountain nappe measured on South Mountain along the main ridge across S-1/2 sec. 22 and N-1/2 sec. 21, T. 4 S., R. 5 W., Stockton 7-1/2minute quadrangle, Utah. [Measured by R.J. Roberts and E.W. Tooker, October, 1961]

\begin{tabular}{|c|c|c|}
\hline & $\begin{array}{l}\text { Thickness } \\
\text { (meters) }\end{array}$ & $\begin{array}{c}\text { Distance above base } \\
\text { (meters) }\end{array}$ \\
\hline $\begin{array}{l}\text { Salvation unit, Oquirrh Group (lowest beds only): Limestone, medium dark-gray, thin } \\
\text { bedded, locally laminated } \\
\text { Contact conformable, } \\
\text { Rush Lake unit, Oquirrh Group: }\end{array}$ & & 1,352 \\
\hline $\begin{array}{l}\text { 37. Quartzite, light gray-tan, sandy, mostly calcareous cement, thin interbedded limy } \\
\text { sandstone and sandy limestone partings and layers in upper part; worm trails in thin } \\
\text { ferruginous layers and brachiopods, crinoids, and fusulinids, in limestones; weathers } \\
\text { light brown-tan to yellow-gray, slight local pitting; brachiopod shells and spines, } \\
\text { crinoid fragments in limestone, and fusulinids in sandy limestones near top; mostly } \\
\text { covered slope. }\end{array}$ & 182 & 1,170 \\
\hline $\begin{array}{l}\text { 36. Limestone, medium dark-gray, fine-grained, medium-bedded, black chert nodules } \\
\text { and lenses; weathers medium gray, chert weathers brown and stands in relief; partly } \\
\text { covered slope. }\end{array}$ & 1 & 1,169 \\
\hline $\begin{array}{l}\text { 35. Quartzite, light gray-tan, sandy, calcareous-cemented, interbedded sandy limestone } \\
\text { and limy sandstone layers and partings, in part banded near top; weathers brown } \\
\text { with thick surface rind; covered slope. }\end{array}$ & 150 & 1.019 \\
\hline $\begin{array}{l}\text { 34. Limestone and quartzite, interbedded; sandy limestone and silica and calcareous-ce- } \\
\text { mented fine-grained to sandy quartzite, local ferruginous sandstone and fine-grained } \\
\text { sandstone layers; mostly covered slope. }\end{array}$ & 133 & 886 \\
\hline $\begin{array}{l}\text { 33. Limestone, medium dark-gray, fine-grained, medium- to thick-bedded; weathers } \\
\text { dark blue-gray, rough pitted surface;abundant well-preserved Syringopora and cup } \\
\text { corals, brachiopods, and fusulinids. } \\
\text { USGS colln. f22609, "Silty bioclastic limestone with_Tetretaris sp., Millerella sp., } \\
\text { textularids, Bradyina sp.,_and Wedekindellina } \text { sp. The age suggested is a Middle Penn- } \\
\text { sylvanian, late Des Moines equivalent." R.C. Douglass written commun. 7/26/62. }\end{array}$ & 2 & 884 \\
\hline $\begin{array}{l}\text { 32. Quartzite, medium-gray, sandy, mostly calcareous cement, medium-bedded with } \\
\text { interbedded thin silica cemented quartzite, interbedded thin sandy limestone layers } \\
\text { in middle part, banded in upper part, crossbedded locally; weathers reddish-tan, } \\
\text { platy to blocky float, in part pitted; sandy limestone contains sparse well-preserved } \\
\text { fusulinids and Syringopora and cup corals at } 52+\mathrm{m} \text {; mostly covered slope. }\end{array}$ & 111 & 773 \\
\hline 31. Quartzite, tan-gray, sandy, cemented by silica; covered slope. & 10 & 763 \\
\hline $\begin{array}{l}\text { 30. Limestone, medium light-gray, fine-grained and silty to sandy, thin-bedded with } \\
\text { interbedded thin (up to } .3 \mathrm{~m} \text { ) calcareous quartzite layers, black chert nodules locally } \\
\text { abundant; weathers yellow gray to tan, platy; covered slope. }\end{array}$ & 12 & 751 \\
\hline $\begin{array}{l}\text { 29. Limestone, medium dark-gray, fine-grained, thin- to medium-bedded, very thinly } \\
\text { laminated in part, sand partings locally, black chert nodules and lenses moderately } \\
\text { abundant; weathers medium blue-gray, platy; well-preserved brachiopods are sparse, } \\
\text { worm trails in yellow-weathered limy sandstone at } 53 \mathrm{~m} \text {; covered slope. }\end{array}$ & 57 & 694 \\
\hline $\begin{array}{l}\text { 28. Quartzite, buff-tan, coarse-sandy, mostly calcareous cement, medium-bedded, band- } \\
\text { ed with minor crossbedding, shaly limestone partings, thin interbedded limestone } \\
\text { layers in basal part; weathers reddish-tan, thick 5-cm partly ferruginous, porous } \\
\text { weathered rind, pitted surface in more silicified beds; sparse silicified Syringopora } \\
\text { coral in limestone at base; mostly covered slope. }\end{array}$ & 91 & 603 \\
\hline $\begin{array}{l}\text { 27. Limestone, medium dark-gray, fine-grained to silty, shaly and thin-bedded; sandy } \\
\text { limestone partings; weathers medium light gray; common well-preserved crinoid, } \\
\text { bryozoan, and brachiopod assemblage; mostly covered slope }\end{array}$ & 7 & 596 \\
\hline $\begin{array}{l}\text { 26. Limestone, medium-gray, fine-grained, dense, medium-bedded to massive, local } \\
\text { laminar bands; weathers blue-gray, pitted surface; sparse, well-preserved silicified } \\
\text { brachiopods, corals, and crinoid fossils; prominent outcrop. }\end{array}$ & 12 & 584 \\
\hline
\end{tabular}




\begin{tabular}{|c|c|c|}
\hline Rush Lake unit, Oquirrh Group-Continued: & $\begin{array}{l}\text { Thickness } \\
\text { (meters) }\end{array}$ & $\begin{array}{l}\text { Distance above base } \\
\text { (meters) }\end{array}$ \\
\hline $\begin{array}{l}\text { 25. Quartzite, light gray-tan, sandy, silica-cemented, banded in part, interbedded fer- } \\
\text { ruginous sandstone layer at } 8 \mathrm{~m} \text {; weathers brown to light tan-brown; covered slope. }\end{array}$ & 25 & 559 \\
\hline $\begin{array}{l}\text { 24. Shale, light-gray, silty, thin-bedded, interbedded thin banded quartzite and sandy } \\
\text { limestone beds; weathers buff to light reddish-brown-gray; platy covered slope. }\end{array}$ & 70 & 489 \\
\hline $\begin{array}{l}\text { 23. Quartzite, light tan-gray, sandy, calcareous cement, medium bedded; weathers tan to } \\
\text { light brown; partly covered slope. }\end{array}$ & 16 & 473 \\
\hline $\begin{array}{l}\text { 22. Limestone, medium gray, sandy, thin-bedded at base, medium-bedded toward top, } \\
\text { sand partings and laminae in lower part,medial 1-meter quartzite layer; weathers } \\
\text { light gray; platy float. }\end{array}$ & 3 & 470 \\
\hline $\begin{array}{l}\text { 21. Quartzite, light gray-brown, sandy, calcareous cement, medium-bedded; weathers } \\
\text { tan. }\end{array}$ & 7 & 463 \\
\hline $\begin{array}{l}\text { 20. Limestone, dark gray, fine grained, medium bedded, dense; weathers light blue- } \\
\text { gray, pitted surface. }\end{array}$ & 1 & 462 \\
\hline $\begin{array}{l}\text { 19. Quartzite and sandstone, medium brown-grey, sandy, calcareous and ferruginous } \\
\text { cement, medium-bedded; weathers tan and dark brown. }\end{array}$ & 9 & 453 \\
\hline $\begin{array}{l}\text { 18. Limestone, medium gray, fine-grained to sandy, medium-bedded, crossbedded lo- } \\
\text { cally; weathers light gray, platy float; sparse, well-preserved small cup corals. }\end{array}$ & 5 & 448 \\
\hline $\begin{array}{l}\text { 17. Quartzite, light gray-tan, sandy, silica-cemented, medium bedded; a } 0.6 \mathrm{~m} \text { thick } \\
\text { interbedded sandy limestone with crossbedded sandy partings at top; weathers tan, } \\
\text { very thin surface rind, slope and ledge outcrops. }\end{array}$ & 14 & 434 \\
\hline $\begin{array}{l}\text { 16. Quartzite, light gray-tan, coarse grained sandy, calcareous-cemented, medium-bed- } \\
\text { ded to massive; weathers light brown,thick porous surface rind, blocky float. }\end{array}$ & 9 & 425 \\
\hline $\begin{array}{l}\text { 15. Limestone, medium gray, silty, medium bedded; weathers yellow-gray to buff, platy; } \\
\text { well-preserved, abundant, crinoid, bryozoan, productid, and spiriferid brachiopod } \\
\text { fauna; mostly covered slope. } \\
\text { USGS colln. 224387-PC at } 23 \text { m, "Derbyia aff. D. crassa (Meek and Hander), } \\
\text { Neochoneltes sp., Grandaurispina sp., J urasania cf. J. nebrascensis (Owen), Can- } \\
\text { crinella cf. C. broonensis (Swallow), Crurithuris cf. C. planoconvexa (Shumard), } \\
\text { Condtathyris perplexa (McChessney), Hustedia mormoni (Marcou), Composita? } \\
\text { sp. indet. (fragment), Beecheria cf. B. bovidens (Morton), Paralleolodon? sp indet., } \\
\text { and Ammonoid indet. (juvenile). The age of this collection of small silicified fossils } \\
\text { is Middle Pennsylvanian (Des Moines), although it can also be somewhat younger } \\
\text { Pennsylvanian." }\end{array}$ & 27 & 368 \\
\hline $\begin{array}{l}\text { 14. Quartzite, light gray, sandy, silica-cemented, thin- to medium-bedded, banded in } \\
\text { part; weathers reddish light gray, hard conchoidal fracture; partly covered slope. }\end{array}$ & 39 & 368 \\
\hline $\begin{array}{l}\text { 13. Limestone, medium dark-gray, fine-grained to silty, thin-bedded; weathers light } \\
\text { gray-tan; common well preserved fenestrate bryozoans and productid and spiriferid } \\
\text { brachiopods; mostly covered slope. }\end{array}$ & 1 & 367 \\
\hline $\begin{array}{l}\text { 12. Quartzite and limestone, interbedded; thin laminated platy sandy limestone and } \\
\text { blocky quartzite, medium bedded; covered slope. }\end{array}$ & 9 & 358 \\
\hline $\begin{array}{l}\text { 11. Limestone, dark gray, fine grained, medium bedded; weathers blue gray, smooth } \\
\text { surface. }\end{array}$ & 1 & 357 \\
\hline $\begin{array}{l}\text { 10. Quartzite, tan-gray, calcareous-cemented quartz grains, medium-bedded; weath- } \\
\text { ers tan to light brown with thin softer weathered surface rind; platy to blocky float, } \\
\text { covered slope. }\end{array}$ & 3 & 354 \\
\hline $\begin{array}{l}\text { 9. Sandy limestone and quartzite, interbedded; medium to medium-bedded, black chert } \\
\text { nodules with sandy margins locally; mostly covered slope. }\end{array}$ & 36 & 318 \\
\hline $\begin{array}{l}\text { 8. Quartzite and shaly limestone, interbedded; well-preserved bryozoans and crinoid } \\
\text { stems in limestone; covered slope. }\end{array}$ & 13 & 305 \\
\hline $\begin{array}{l}\text { 7. Shaly limestone, medium dark-gray, silty, thin-bedded to platy at top; weathers } \\
\text { purple gray and medium gray; brachiopods, bryozoans at base; mostly covered. }\end{array}$ & 36 & 269 \\
\hline
\end{tabular}




\begin{tabular}{|c|c|c|}
\hline Rush Lake unit, Oquirrh Group_Continued: & $\begin{array}{l}\text { Thickness } \\
\text { (meters }\end{array}$ & $\begin{array}{l}\text { Distance above base } \\
\text { (meters) }\end{array}$ \\
\hline $\begin{array}{l}\text { 6. Limestone, medium gray, medium to fine grained, medium bedded; weathers me- } \\
\text { dium light gray, rough pitted surface, fossils rare. }\end{array}$ & 3 & 266 \\
\hline $\begin{array}{l}\text { 5. Sandstone, reddish-brown and tan, sandy, calcareous cement to part, medium-bed- } \\
\text { ded; weathers light brown-tan; mostly covered slope. }\end{array}$ & 7 & 259 \\
\hline $\begin{array}{l}\text { 4. Quartzite, brown-tan, sandy mostly silica cemented quartz grains, but is slightly } \\
\text { calcareous, medium-bedded with thin interbeds of calcareous sandstone; weathers } \\
\text { light brown tan with smooth surface; upper part covered slope. }\end{array}$ & 31 & 228 \\
\hline $\begin{array}{l}\text { 3. Limestone, medium gray and tan, silty and sandy, chert nodules, in part bioclastic, } \\
\text { interbedded with thin }(5 \mathrm{~cm}) \text { quartzite and shale partings; weathers medium light } \\
\text { gray-brown and yellow-brown;fenestrate and stem bryozoans, and brachiopods lo- } \\
\text { cally abundant. }\end{array}$ & 27 & 201 \\
\hline $\begin{array}{l}\text { 2. Limestone, medium-gray, silty to sandy, thin and platy to medium-bedded,, inter- } \\
\text { bedded shaly and sandy units, crossbedded in part, locally thin interbedded cherty } \\
\text { limestone units; weathers medium light gray and yellow brown; bryozoans. } \\
\text { USGS colln. 61F70A at } 169 \text { feet, "Fistuliporoid (?) bryozoan, indet., Fenestella sp., } \\
\text { Polypora sp., Archimedes sp. (fragments of fronds), Penniretepra sp., rhomboproid } \\
\text { bryozoans, crinoid colummals, Juresania sp. indet." Fauna is compatible with Des } \\
\text { Moines age of section." (Mackenzie Gordon, Jr., written commun. 10/14/66) }\end{array}$ & 30 & 171 \\
\hline $\begin{array}{l}\text { 1. Limestone, medium gray, fine grained to sandy, thin bedded, and distinctly lam- } \\
\text { inated and locally convoluted, to medium bedded; black chert nodules moderalely } \\
\text { abundant in medium-bedded rock, shale partings common, and sandy bioclastic rock } \\
\text { locally abundant; weathers medium light gray, chert nodules to light sandy-brown; } \\
\text { locally brecciated medium sandy layers; fossiliferous with coral bryozoan, and } \\
\text { crinoid stems, and small brachiopods } \\
\text { USGS colln f22608 at } 3 \text { m, "Bioclastic limestone with Bradyina, textularids, and } \\
\text { Fusulina sp. The age suggested is Middle Pennsylvanian, late Des Moines equiva- } \\
\text { lent." (R.C. Douglass, written commun. 7/20/62) }\end{array}$ & 171 & \\
\hline Total Rush Lake unit measured & 1,352 & \\
\hline Conformable contact (?), lower part of the Rush Lake unit is covered by alluvium. & & \\
\hline
\end{tabular}

